DOE/EA-1037

\title{
Final \\ Environmental Assessment for the \\ Uranium Lease Management Program
}

July 1995

DISCLAIMER

This report was prepared as an account of work sponsored by an agency of the United States Government. Neither the United States Government nor any agency thereof, nor any of their employees, makes any warranty, express or implied, or assumes any legal liability or responsibility for the accuracy, completeness, or usefulness of any information, apparatus, product, or process disclosed, or represents that its use would not infringe privately owned rights. Reference herein to any specific commercial product, process, or service by trade name, trademark, manufacturer, or otherwise does not necessarily constitute or imply its endorsement, recommendation, or favoring by the United States Government or any agency thereof. The views and opinions of authors expressed herein do not necessarily state or reflect those of the United States Government or any agency thereof. 


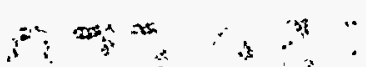

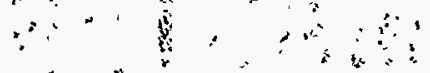




\section{DISCLAIMER}

Portions of this document may be illegible in electronic image products. Images are produced from the best available original document. 
Abbreviations and Acronyms $\ldots \ldots \ldots \ldots \ldots \ldots \ldots \ldots$ vii

Glossary $\ldots \ldots \ldots \ldots \ldots \ldots \ldots \ldots \ldots \ldots \ldots \ldots \ldots \ldots \ldots \ldots \ldots \ldots$

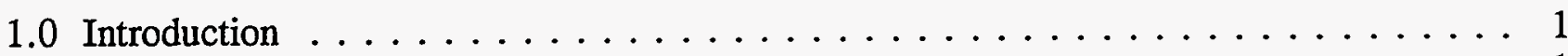

1.1 Background . . . . . . . . . . . . . . . . 1

1.2 History of the Uranium Lease Management Program . . . . . . . . . . 1

1.3 Scope of the Environmental Assessment $\ldots \ldots \ldots \ldots \ldots \ldots$

2.0 Purpose and Need for Action $\ldots \ldots \ldots \ldots \ldots \ldots \ldots \ldots \ldots$

3.0 Description of Alternatives . . . . . . . . . . . . . . 9

3.1 Elimination of Alternative Actions $\ldots \ldots \ldots \ldots \ldots \ldots$

3.2 Proposed Action Alternative . . . . . . . . . . . . . 10

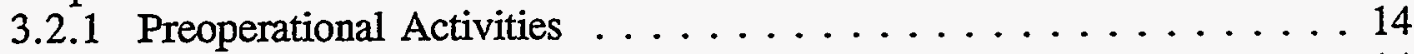

3.2.1.1 Surface Exploration . . . . . . . . . . . . 14

3.2.1.2 Mine-Site Preparation . . . . . . . . . . . . . 16

3.2 .2 Operational Activities . . . . . . . . . . . . . . 18

3.2.2.1 Surface-Plant Area Construction and Operation . . . . . 18

Buildings/Utilities . . . . . . . . . . . . 18

Service Area . . . . . . . . . . . . . . . 19

Storage . . . . . . . . . . . . . . . 19

Security of Potential Safety Hazard Areas . . . . . . . . 19

Mine-Water Discharge/Treatment Ponds . . . . . . . . 20

Mine-Rock Waste Piles . . . . . . . . . . . . . 20

Nonhazardous Waste . . . . . . . . . . 20

Hazardous Waste . . . . . . . . . . . . . . 21

3.2.2.2 Mine Development and Operation ........... 21

Underground Mines . . . . . . . . . . . . 21

Surface/Open-Pit Mines . . . . . . . . . . 23

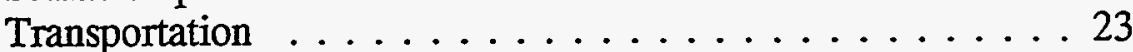

3.2 .3 Postoperational Activities . . . . . . . . . . . . 26

3.2.3.1 Interim Shutdown Activities . . . . . . . . . 26

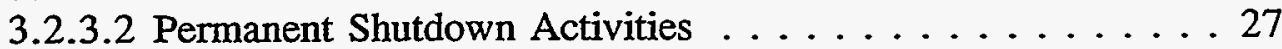

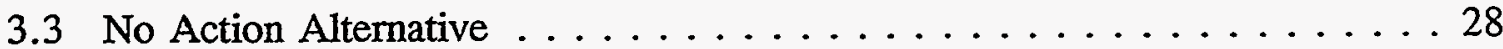

3.4 ULMP Termination Alternative $\ldots \ldots \ldots \ldots \ldots \ldots \ldots \ldots \ldots$

4.0 Affected Environment . . . . . . . . . . . . . . . . . . . . . 29

4.1 Environmental Setting . . . . . . . . . . . . . . . . . . 29

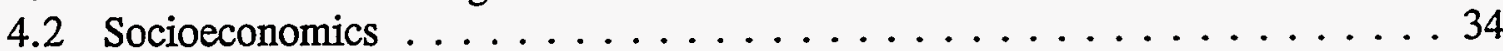

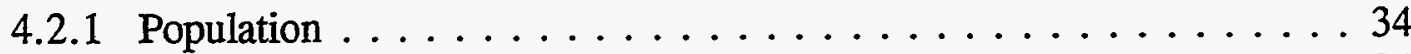

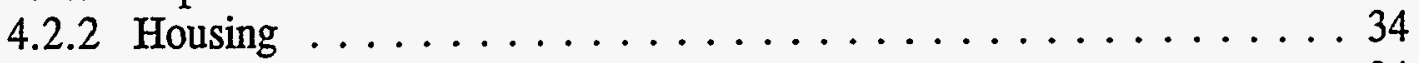

4.2.3 Employment and Economic Structure $\ldots \ldots \ldots \ldots \ldots$ 
4.3 Transportation . . . . . . . . . . . . . . . 35

4.4 Land Use . . . . . . . . . . . . . . . . . 36

4.4 .1 Mining . . . . . . . . . . . . . . . 37

4.4 .2 Recreation . . . . . . . . . . . . . . 37

4.4 .3 Timber Harvesting . . . . . . . . . . . . . 38

4.4 .4 Agriculture and Grazing $\ldots \ldots \ldots \ldots \ldots \ldots \ldots \ldots \ldots \ldots$

4.5 Air Quality . . . . . . . . . . . . . . . . . 38

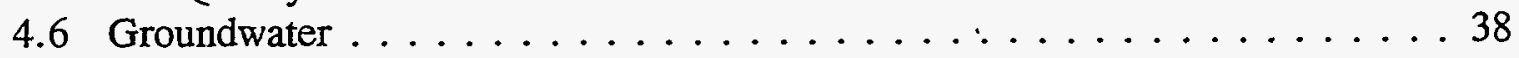

4.7 Surface Water . . . . . . . . . . . . . . . . . . 39

4.8 Soils . . . . . . . . . . . . . . . . . . 40

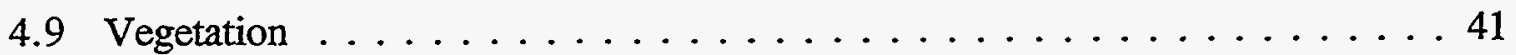

4.10 Wildlife . . . . . . . . . . . . . . . . . . . 42

4.11 Cultural/Historical Resources . . . . . . . . . . . . . . 43

4.12 Visual Resources . . . . . . . . . . . . . . . . . . 47

4.13 Wilderness Areas $\ldots \ldots \ldots \ldots \ldots \ldots \ldots \ldots \ldots$

4.14 Noise . . . . . . . . . . . . . . . . . . . 48

4.15 Wild and Scenic Rivers . . . . . . . . . . . . . . 48

4.16 Floodplains and Wetlands $\ldots \ldots \ldots \ldots \ldots \ldots \ldots \ldots . \ldots \ldots$

4.17 Human Health . . . . . . . . . . . . . . . . . . . . 49

4.17 .1 Radiological Hazards . . . . . . . . . . . . . . 49

4.17 .2 Nonradiological Hazards . . . . . . . . . . . . . 50

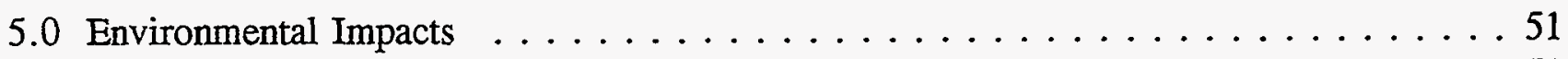

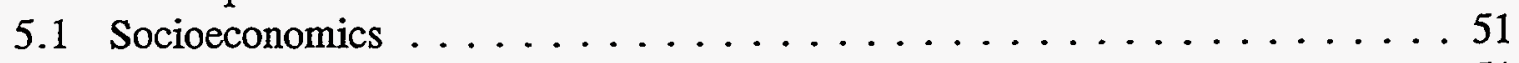

$5.1 .1 \quad$ Proposed Action Alternative . . . . . . . . . . 51

5.1.2 No Action and ULMP Termination Alternatives . . . . . . 51

5.2 Transportation . . . . . . . . . . . . . . . 51

$5.2 .1 \quad$ Proposed Action Alternative . . . . . . . . . . . 51

5.2 .2 No Action and ULMP Termination Alternatives . . . . . . 54

5.3 Land Use . . . . . . . . . . . . . . . . . . 55

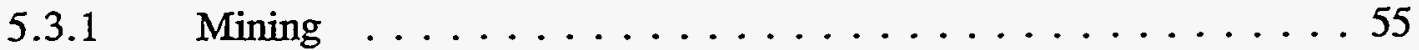

5.3.1.1 Proposed Action Alternative . . . . . . . . . 55

5.3.1.2 No Action and ULMP Termination Alternatives .... 55

$5.3 .2 \quad$ Recreation . . . . . . . . . . . . . . 55

5.3.2.1 Proposed Action Alternative . . . . . . . . . . 55

5.3.2.2 No Action and ULMP Termination Alternatives . . . . 56

5.3 .3 Timber Harvesting . . . . . . . . . . . . . 56

5.3.3.1 Proposed Action Alternative . . . . . . . . . . 56

5.3.3.2 No Action and ULMP Termination Alternatives . . . . 56

$5.3 .4 \quad$ Agriculture and Grazing $\ldots \ldots \ldots \ldots \ldots \ldots \ldots$

5.3.4.1 Proposed Action Alternative . . . . . . . . . . 56

5.3.4.2 No Action and ULMP Termination Alternatives . . . 5 56 


\section{Contents (continued)}

5.4 Air Quality . . . . . . . . . . . . . . . . . . . . 57

5.4 .1 Proposed Action Alternative . . . . . . . . . . . . 57

5.4 .2 No Action and ULMP Termination Alternatives . . . . . . . . 57

5.5 Groundwater . . . . . . . . . . . . . . . . . . 57

5.5 .1 Proposed Action Alternative . . . . . . . . . . . 57

5.5.2 No Action and ULMP Termination Alternatives . . . . . . . . 58

5.6 Surface Water . . . . . . . . . . . . . . . . . . . . . 58

5.6 .1 Proposed Action Alternative . . . . . . . . . . . 58

5.6 .2 No Action and ULMP Termination Alternatives . . . . . . . 58

5.7 Soils . . . . . . . . . . . . . . . . . . . . . . . . . 59

5.7 .1 Proposed Action Alternative . . . . . . . . . . . . 59

5.7.2 No Action and ULMP Termination Alternatives . . . . . . . . 59

5.8 Vegetation . . . . . . . . . . . . . . . . . . . . . 59

5.8 .1 Proposed Action Alternative . . . . . . . . . . . . . 59

5.8 .2 No Action and ULMP Termination Alternatives . . . . . . . . 59

5.9 Wildlife . . . . . . . . . . . . . . . . . . . . 60

5.9 .1 Proposed Action Alternative $\ldots \ldots \ldots \ldots \ldots 6 \ldots$

5.9.2 No Action and ULMP Termination Alternatives . . . . . . . 60

5.10 Cultural/Historical Resources . . . . . . . . . . . . . . . 61

5.10 .1 Proposed Action Alternative $\ldots \ldots \ldots \ldots \ldots 61$

5.10 .2 No Action and ULMP Termination Alternatives . . . . . 61

5.11 Visual Resources . . . . . . . . . . . . . . . . . 61

5.11 .1 Proposed Action Alternative $\ldots \ldots \ldots \ldots \ldots 61$

5.11.2 No Action and ULMP Termination Alternatives . . . . . 61

5.12 Wilderness Areas . . . . . . . . . . . . . . . . . . . 62

5.12.1 Proposed Action Alternative . . . . . . . . . . 62

5.12.2 No Action and ULMP Termination Alternatives $\ldots \ldots \ldots 62$

5.13 Noise . . . . . . . . . . . . . . . . . . . . . . 62

5.13 .1 Proposed Action Alternative $\ldots \ldots \ldots \ldots \ldots 62$

5.13.2 No Action and ULMP Termination Alternatives $\ldots \ldots \ldots 62$

5.14 Wild and Scenic Rivers . . . . . . . . . . . . . . . . . 62

5.15 Floodplains and Wetlands . . . . . . . . . . . . . 63

5.15.1 Proposed Action Alternative $\ldots \ldots \ldots \ldots \ldots 63$

5.15.2 No Action and ULMP Termination Alternatives $\ldots \ldots \ldots 63$

5.16 Human Health . . . . . . . . . . . . . . . . . . . 63

5.16 .1 Proposed Action Alternative $\ldots \ldots \ldots \ldots \ldots \ldots 63$

5.16.1.1 Radiological Hazards . . . . . . . . . . 63

5.16.1.2 Nonradiological Hazards . . . . . . . . . . . 64

5.16 .2 No Action and ULMP Termination Alternatives $\ldots \ldots \ldots \ldots 64$

5.16.2.1 Radiological Hazards . . . . . . . . . . . 64

5.16.2.2 Nonradiological Hazards . . . . . . . . . . . 65

5.17 Environmental Justice Considerations . . . . . . . . . . . . 65

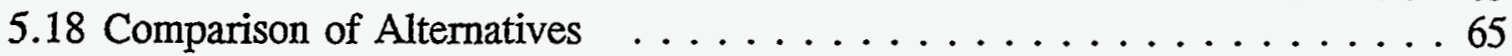


6.0 List of Persons Consulted . . . . . . . . . . . . . . . 67

7.0 References . . . . . . . . . . . . . . . . . . . 69

\section{Figures}

Figure 1. Uranium Lease Management Program Lease Tract Map . . . . . . . . 3

2. Transportation Haul Routes $\ldots \ldots \ldots \ldots \ldots \ldots \ldots \ldots \ldots$

3. Uravan Lease Tract Area . . . . . . . . . . . . . . . . . . . 30

4. Paradox Valley Lease Tract Area . . . . . . . . . . . . 32

5. Slick Rock Lease Tract Area . . . . . . . . . . . . . . . 33

\section{Tables}

Table 1. Cross Reference Numbers for DOE Lease Tracts . . . . . . . . . . 2

2 Summary of Lease Tract Information . . . . . . . . . . . . 11

3. Threatened and Endangered Species that Could Occur On Uranium Lease Tracts . . . . . . . . . . . . . . . . . . . . 44

4. Summary of Environmental Impacts . . . . . . . . . . . . . 52

A-1. Common and Scientific Names of Plants Associated with DOE Lease Tracts . . . . . . . . . . . . . . . . . . A

A-2. Wildlife Species Expected to Occur On or Near the DOE Lease Tracts . . . . . . . . . . . . . . A-5

\section{Appendices}

Appendix A Plant and Wildlife Species On and Near DOE Lease Tracts . . . . A A-1

Appendix B Resolution of Public Comments Regarding Draft Environmental Assessment for the Uranium Lease Management Program . . . . . . . B-1 


\section{Abbreviations and Acronyms}

$\begin{array}{ll}\text { AEC } & \text { U.S. Atomic Energy Commission } \\ \text { AUM } & \text { animal unit month } \\ \text { BLM } & \text { Bureau of Land Management } \\ \text { CDPHE } & \text { Colorado Department of Public Health and Environment } \\ \text { CFR } & \text { U.S. Code of Federal Regulations } \\ \text { COE } & \text { U.S. Army Corps of Engineers } \\ \text { DOE } & \text { U.S. Department of Energy } \\ \text { DOT } & \text { U.S. Department of Transportation } \\ \text { EA } & \text { Environmental Assessment } \\ \text { EPA } & \text { U.S. Environmental Protection Agency } \\ \text { ERMA } & \text { Extensive Recreation Management Area } \\ \text { GJPO } & \text { Grand Junction Projects Office } \\ \text { LHD } & \text { load/haul/dump } \\ \text { mg/L } & \text { milligrams per liter } \\ \text { mrem/yr } & \text { millirem per year } \\ \text { MSDS } & \text { Material Safety Data Sheet } \\ \text { MSHA } & \text { Mine Safety and Health Act } \\ \text { NEPA } & \text { National Environmental Policy Act } \\ \text { NORM } & \text { naturally occurring radioactive material } \\ \text { NRC } & \text { U.S. Nuclear Regulatory Commission } \\ \text { OSA } & \text { Outstanding Scenic Area } \\ \text { pCi/g } & \text { picocuries per gram } \\ \text { ROW } & \text { right-of-way } \\ \text { SRMA } & \text { Special Recreation Management Area } \\ \text { TDS } & \text { total dissolved solids } \\ \text { TEDE } & \text { total effective dose equivalent } \\ \text { T\&E } & \text { threatened or endangered } \\ \text { ULMP } & \text { Uranium Lease Management Program } \\ \text { WSA } & \text { Wilderness Study Area } \\ & \end{array}$


Intentionally Blank 


\section{Glossary}

Adit-A nearly horizontal passageway leading into a mine.

Animal Unit Month-An AUM is generally one of the following: one cow, one cow and one calf, one horse, or five sheep. The number of acres required to support an AUM varies depending upon range condition, rainfall, irrigation, topography, etc. Because of low rainfall and steep topography, a larger number of acres is required to support an AUM in the area of the lease tracts than on most public lands. The number of acres required to support an AUM is expressed in $x$ acres per AUM.

Back-Ceiling of a mine working.

Committed Dose Equivalent-The predicted total dose equivalent to a tissue or an organ over a 50-year period after a known intake of a radionuclide into the body. It does not include contributions from external dose.

Committed Effective Dose Equivalent-The sum of the committed dose equivalents to various tissues in the body, each multiplied by the appropriate weighing factor.

Committed effective dose equivalent is expressed in units of rem.

Deep Dose Equivalent-The dose equivalent in tissue at a depth of 1 centimeter derived from external radiation.

Exposure-Being exposed to ionizing radiation or to radioactive material.

Effective Dose Equivalent-The sum of the products of absorbed dose and appropriate factors that accounts for differences in biological effectiveness. Differences in biological effectiveness may occur as a result of differences in the quality of radiation and its distribution in the body. Effective dose equivalent is expressed in units of rem.

Gamma Radiation-Emission of gamma rays through space or solid media.

Gamma Ray-Electromagnetic radiation having a wavelength of $10^{-9}$ centimeters or less.

Incline/Decline-A nonhorizontal slanted passageway leading into a mine.

Member of the Public-An individual in a controlled or unrestricted area on the lease tracts. The individual would not be involved in mining operations but could be a receiver of radiation doses. Any individual receiving an occupational dose would not be considered a member of the public.

Mine-Rock Waste Pile-Topographic feature associated with mining operations that contains host rock and naturally occurring radioactive material (NORM) and usually is not cost-effective to process further. 


\section{Glossary (continued)}

Muck-The loading and removal of ore or mine-rock waste from a mine.

Pre-1974 Site-A mine site and associated environmental disturbance resulting from mining and exploration activities that occurred prior to the beginning of the current lease period.

Rem-The dosage of radiation that will cause the same biological effect as 1 roentgen of gamma-ray exposure.

Shaft-A near-vertical passageway leading into a mine from the surface of the ground.

Surface Plant Area-An area developed to support mining-related operations that includes all structures (e.g., maintenance shops, crew trailers, office buildings), orestorage pads, mine-rock waste piles, and topsoil stockpiles.

Total Effective Dose Equivalent-The sum of the deep-dose equivalent (for external exposure) and the committed effective dose equivalent (for internal exposure).

Vent-A near-vertical passage leading into a mine that provides additional ventilation.

Working Level-Any combination of short-lived radon daughters in 1 liter of air that results in the ultimate emission of $1.3 \times 10^{5}$-million electron volts of potential alphaparticle energy.

Working Level Month-An exposure to 1 Working Level for 170 hours. 


\subsection{Introduction}

\subsection{Background}

The U.S. Department of Energy (DOE) Grand Junction Projects Office (GJPO) is evaluating the Uranium Lease Management Program (ULMP) to determine if it is in the U.S. Government's best interest to continue leasing withdrawn lands and DOE-owned patented claims (herein referred to as DOE-managed lands) for the exploration and production of uranium and vanadium ores. The Domestic Uranium Program regulation, codified at Title 10, Part 760.1, of the U.S. Code of Federal Regulations (CFR), gives DOE the flexibility to continue leasing these lands under the ULMP if the agency determines that it is in its best interest to do so. A key element in determining what is in DOE's "best interest" is the assessment of the environmental impacts attributable to lease tract operations and associated activities.

\subsection{History of the Uranium Lease Management Program}

In the post-World War II era, the U.S. Atomic Energy Commission (AEC) was charged with the responsibility of developing a supply of domestic uranium adequate to meet the nation's defense needs. That responsibility was met through the Ore Purchase Program, the Exploration Program, and the initial Uranium Leasing Program (1949-1962). Provisions from these programs gave AEC the authority to withdraw Federal lands for the exploration and development of a viable domestic uranium source and were carried forward into the Atomic Energy Act of 1954.

In 1974, a second leasing program (currently known as the ULMP) was initiated under the Domestic Uranium Program regulation (10 CFR 760.1) that was markedly different from the initial Uranium Leasing Program of negotiated leases, compulsory mill purchases, and guaranteed prices. The new program was designed to address the lack of production capacity of uranium- and vanadium-bearing ores for U.S. Government defense needs and emphasized the need for uranium in the expanding commercial nuclear energy market. The program was initiated while milling facilities still existed in the area. Two main goals of the program were to recover the resources that had been developed initially by AEC and to improve the prospects for continued mill operation, thereby encouraging further exploration and development on privately held land.

AEC (and its successor agencies, the U.S. Energy Research and Development Administration and DOE) was tasked with administering the program. Forty-three lease tracts located in Colorado (38 lease tracts), Utah (4 lease tracts), and New Mexico (1 lease tract) that contain approximately 25,000 acres were included in the ULMP (see Table 1 and Figure 1). Most of these lease tracts lie in a mineralized area known as the Uravan Mineral Belt that includes a significant, if not dominant, portion of the known domestic uranium ore reserves. 
Table 1. Cross Reference Numbers for DOE Lease Tracts

\begin{tabular}{|c|c|c|c|}
\hline $\begin{array}{c}\text { Lease Tract } \\
\text { Designationa }\end{array}$ & $\begin{array}{c}\text { Reference } \\
\text { Number } \\
\text { Used in EA }\end{array}$ & $\begin{array}{l}\text { Lease Tract } \\
\text { Designationa }\end{array}$ & $\begin{array}{c}\text { Reference } \\
\text { Number } \\
\text { Used in EA }\end{array}$ \\
\hline $\mathrm{NM}-\mathrm{B}-1$ & 1 & $C-S R-15 A$ & $15 \mathrm{~A}$ \\
\hline$U-C W-2$ & 2 & $C-S R-16$ & 16 \\
\hline$U-C W-2 A$ & $2 \mathrm{~A}$ & C-SR-16A & $16 \mathrm{~A}$ \\
\hline $\mathrm{U}-\mathrm{H}-3$ & 3 & $C-W M-17$ & 17 \\
\hline$U-E-4$ & 4 & $C-W M-17 A$ & $17 \mathrm{~A}$ \\
\hline$C-J D-5$ & 5 & $C-S M-18$ & 18 \\
\hline C-JD-5A & $5 A$ & C-AM-19 & 19 \\
\hline$C-J D-6$ & 6 & C-AM-19A & $19 \mathrm{~A}$ \\
\hline C-JD-7 & 7 & $C-A M-20$ & 20 \\
\hline$C-J D-7 A$ & 7A & $C-L P-21$ & 21 \\
\hline C-JD-8 & 8 & $C-L P-22$ & 22 \\
\hline$C-J D-8 A$ & $8 \mathrm{~A}$ & $C-L P-22 A$ & $22 \mathrm{~A}$ \\
\hline C-JD-9 & 9 & $C-L P-23$ & 23 \\
\hline$C-S R-10$ & 10 & $C-B L-23 A$ & $23 \mathrm{~A}$ \\
\hline$C-S R-11$ & 11 & $C-B L-23 B$ & $23 B$ \\
\hline C-SR-11A & $11 \mathrm{~A}$ & $C-C M-24$ & 24 \\
\hline C-SR-12 & 12 & $\mathrm{C}-\mathrm{CM}-25$ & 25 \\
\hline C-SR-13 & 13 & C-G-26 & 26 \\
\hline C-SR-13A & $13 \mathrm{~A}$ & $C-G-26 A$ & $26 \mathrm{~A}$ \\
\hline C-SR-14 & 14 & $C-G-27$ & 27 \\
\hline C-SR-14A & $14 \mathrm{~A}$ & $C-G-27 A$ & $27 A$ \\
\hline C-SR-15 & 15 & & \\
\hline
\end{tabular}

aNM = New Mexico; U =Utah; $\mathrm{C}=$ Colorado; $\mathrm{B}=$ Bluewater; $\mathrm{CW}=$ Cottonwood Wash; $\mathrm{H}=$ Hideout Mesa; $E=E l k$ Ridge; $J D=J o$ Dandy; $S R=$ Slick Rock; $W M=$ Wedding Bell Mountain; $S M=$ Spring Creek Mesa; $A M=$ Atkinson Mesa; $L P=$ Long Park; $B L=$ Bitter Creek/Long Park; $C M=$ Club Mesa; $G=$ Gateway. 


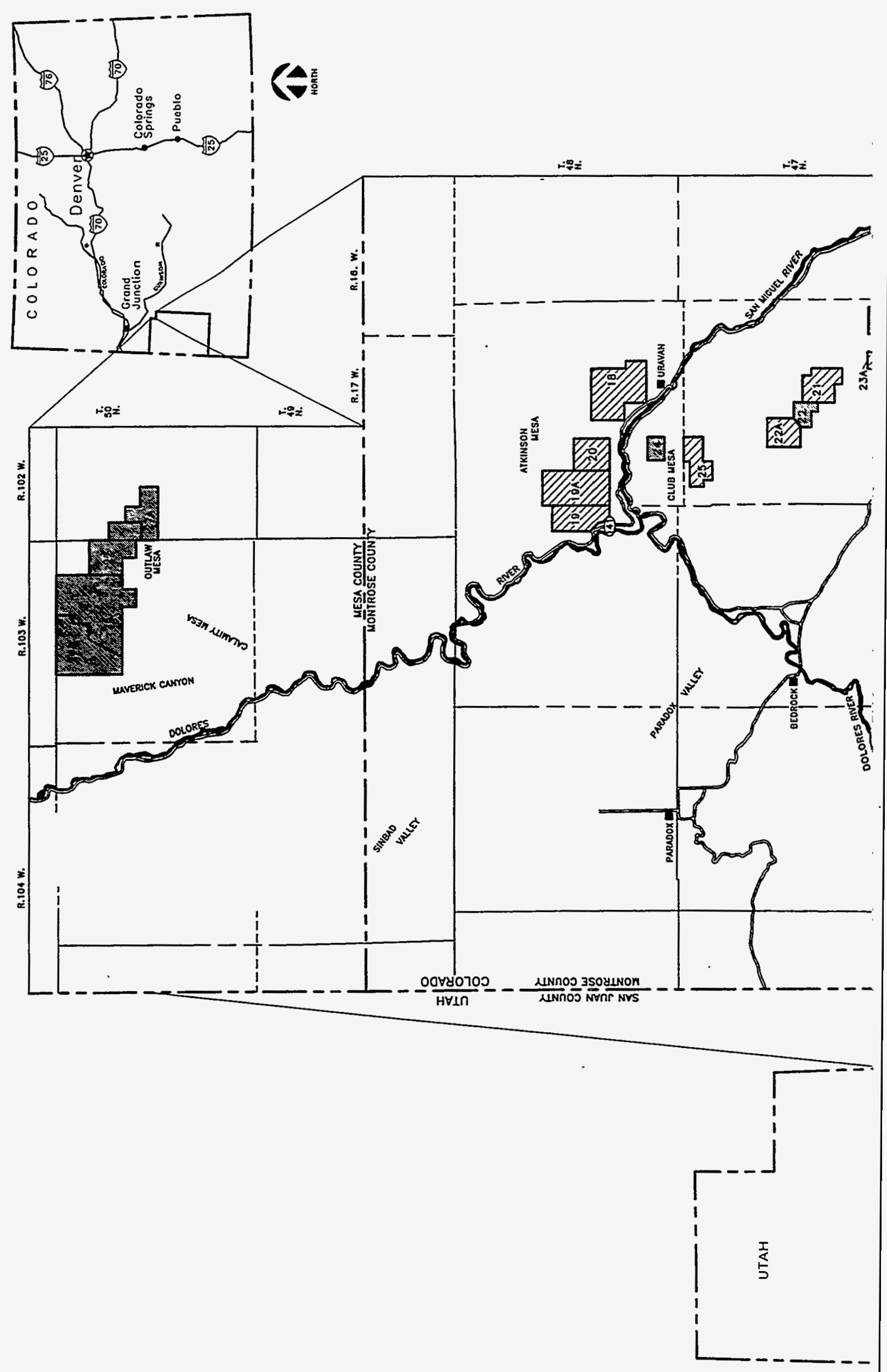


Since 1974, DOE has controlled and administered these 43 lease tracts for the exploration and development of viable uranium and vanadium resources. As part of its administrative duties, DOE incorporated language into each lease agreement that required leaseholders to conduct operations in a manner that minimized adverse environmental effects and to comply with State and Federal statutes and regulations. DOE was responsible for monitoring lease tract activities and enforcing stipulations established in the lease agreements. To help ensure reclamation, DOE required leaseholders to be bonded.

In 1984, only 33 of the original 43 lease agreements were renewed for a second 10-year period under the leases' renewal option. The renewed lease agreements were identical to the original agreements signed in 1974 except for a separate renewal clause and amendments that modified the methods for calculating royalties. During the ensuing 10 years, three additional lease agreements were relinquished to or terminated by DOE. One of the terminated lease tracts (lease tract 1) was reclaimed in 1992 under a U:S. Environmental Protection Agency (EPA) response action and was subsequently restored by the U.S. Department of Interior Bureau of Land Management (BLM) in November 1994 to the public domain. In 1994, the remaining 30 leases were allowed to expire and are no longer eligible for automatic extension or renewal. While DOE is preparing this Environmental Assessment (EA), the former leaseholders are being allowed to continue maintenance, security, and reclamation activities at the lease tracts to ensure that the mines and associated facilities do not incur damage.

\subsection{Scope of the Environmental Assessment}

This document is a programmatic EA that addresses the potential environmental concerns related to a policy decision to continue leasing DOE-managed lands. Under the Proposed Action Alternative, DOE would enter into negotiations for new lease agreements with former leaseholders. The new lease agreements would allow the leaseholders to (1) resume historical operations on the lease tracts; (2) propose and potentially perform new lease activities associated with exploring, developing, and mining new and existing ore reserves; (3) transport ores from the lease tracts to existing processing facilities; and (4) perform all activities required to satisfactorily reclaim environmental disturbances on the lease tracts resulting from their operations. Additionally, this document addresses the potential environmental concerns associated with "no action" alternatives that would limit future lease activities to the reclamation of existing environmental disturbances. Under the no action alternatives, the DOE-managed lands would be either (1) retained under DOE's administrative control indefinitely (hereinafter referred to as the "No Action Alternative") or (2) restored to the public domain under BLM's administrative control (hereinafter referred to as the "ULMP Termination Alternative").

As part of the EA process, DOE solicited environmental data and other pertinent information from the former leaseholders (DOE 1994a) and requested that they notify DOE of their "nonbinding intention regarding participation in any future program" (DOE 1994b). Former leaseholders of 22 of the 30 lease tracts indicated that they intend to participate in the

program. Former leaseholders of the eight remaining lease tracts indicated that they have no 
further interest in participating in the program and have requested relinquishment of their respective leases.

In response to these requests for relinquishment, DOE will identify the reclamation activities that must be performed by the former leaseholders in accordance with the lease agreements. DOE will approve relinquishment only after reclamation has been completed satisfactorily. The 22 lease tracts for which former leaseholders have indicated an interest in maintaining in the ULMP are addressed in this EA. The other 20 lease tracts are excluded indefinitely from future leasing. The 22 lease tracts discussed in this EA are distributed over three geographical areas located within two counties of Colorado and are referred to as the Uravan lease tracts, the Paradox Valley lease tracts, and the Slick Rock lease tracts. Geographical features of these lease tract areas are discussed in Section 4.1, Environmental Setting. 


\subsection{Purpose and Need for Action}

The purpose of the ULMP is to maintain and preserve the nation's immediately accessible supply of domestic uranium and vanadium ores, to maintain a viable domestic mining and milling infrastructure required to produce and mill these ores, and to provide assurance of a fair monetary return to the U.S. Government. 
Intentionally Blank 


\subsection{Description of Alternatives}

DOE considered a number of actions that could be undertaken to support the

U.S. Government's purpose and need, as well as actions that could be initiated if leasing of the DOE-managed lands were terminated indefinitely. This chapter presents an overview of the selection process and a description of the alternatives considered.

\subsection{Elimination of Alternative Actions}

DOE considered various alternative actions to determine each action's ability to (1) support the stated need of preserving the nation's immediately accessible supply of domestic uranium and vanadium ores, (2) maintain a viable domestic mining and milling infrastructure to produce and mill these ores, and (3) provide assurance of a fair monetary return to the U.S. Government. The following alternative actions were considered but eliminated:

- Developing and maintaining uranium mines at other domestic geographic locations outside the Uravan Mineral Belt. This alternative was eliminated because ore deposits outside the Uravan Mineral Belt do not have the same quantity or quality of proven uranium and vanadium ore reserves as the existing lease tracts.

- Processing existing stocks of domestic weapons-grade uranium for all U.S. Government uranium needs. This alternative was eliminated because the U.S. Government would not have immediate access to domestic ore reserves and could not ensure long-term access to these domestic sources. Additionally, vanadium reserves would not be readily available.

- Transferring lease management responsibilities to BLM through some form of interagency agreement, with DOE retaining the lands in withdrawn status. This alternative was eliminated because BLM officials have indicated that they would only accept responsibility for managing withdrawn lands that would be subject to multiple use.

- Maintaining the leases in "expired" status under DOE's continued administrative control and authority until such time in the future when uranium and/or vanadium ores are needed. At that time, DOE would enter into new lease agreements with the former leaseholders. In the interim period, DOE would routinely monitor the lease tracts and effectuate activities required to maintain the lease tract improvements in operable condition. Final reclamation of the existing mine sites would be delayed indefinitely. This alternative was eliminated because it would (1) discourage further industry investments in exploration activities, (2) allow the deterioration of the domestic mining and milling industry infrastructure, (3) require a considerable annual investment from DOE to maintain the lease tract improvements in operable condition, 
(4) delay and potentially eliminate all future royalties, and (5) potentially delay the reclamation of existing environmental disturbances beyond the viable existence of the responsible parties.

\subsection{Proposed Action Alternative}

DOE proposes to continue the ULMP, as authorized by the Atomic Energy Act of 1954, by retaining the lands in withdrawn status and leasing the lands to former leaseholders interested in continuing their participation in the program. Continuation of the ULMP would allow 10 years of exploration, development, and mining on the 22 lease tracts. At the end of 10 years, DOE would evaluate the ULMP to determine if leasing activities should continue.

On the basis of current demand for uranium and vanadium, the level and types of mining activity expected under the Proposed Action Alternative would be similar to historical activities. Historically, activities conducted on the lease tracts occurred in three phases: preoperational (exploration), operational (mining), and postoperational (reclamation). On seven of the lease tracts, only preoperational activities occurred; on the remaining 15 lease tracts, two or more phases occurred. Of the 11,536 acres (4,670 hectares) comprising the 22 lease tracts, approximately 258 acres (104 hectares) were actually disturbed or environmentally affected by lease operations. About 75 percent of this disturbance (approximately 190 acres or 76 hectares) was associated with operations on lease tract 7. Table 2 lists the historical acreage of disturbance and activities conducted on the 22 lease tracts.

Preoperational, operational, and postoperational activities would resume on the lease tracts under the Proposed Action Alternative. New lease agreements, including applicable stipulations, would be issued to leaseholders before operations were resumed and would allow the leaseholder to pursue any of the preoperational, operational, and postoperational activities described in the following subsections. However, DOE approval would be required for all lease activities, and further environmental review of a proposed activity might be required prior to DOE's approval.

Some new surface disturbances would require review or approval by agencies outside DOE. The following are examples of situations that would require outside-agency review or approval.

- For all proposed preoperational, operational, and postoperational activities where surface disturbance would occur, the leaseholder would be required to obtain an appropriate permit in accordance with the Mineral Rules and Regulations of the Colorado Mined Land Reclamation Board (Colorado Department of Natural Resources 1995). The nature of the permit would depend on the proposed activities. 
Table 2. Summary of Le

\begin{tabular}{|c|c|c|c|c|c|}
\hline Characteristic & Lease Tract 5 & Lease Tract 6 & Lease Tract 7 & Lease Tract 7A & Lease Tract 8 \\
\hline $\begin{array}{l}\text { Location of Lease } \\
\text { Tracts }\end{array}$ & $\begin{array}{c}\text { Secs. } 21,22 ; \\
\text { T46N, R17W, } \\
\text { NMPM }\end{array}$ & $\begin{array}{c}\text { Secs. 21,22; } \\
\text { T46N, R17W, } \\
\text { NMPM }\end{array}$ & $\begin{array}{c}\text { Secs. 16,21,22; } \\
\text { T46N, R17W, } \\
\text { NMPM }\end{array}$ & $\begin{array}{l}\text { Secs. } 16,17 \text {, } \\
21,22 ; \mathrm{T} 46 \mathrm{~N} \text {, } \\
\text { R17W, NMPM }\end{array}$ & $\begin{array}{c}\text { Secs. } 17,18,19, \\
20 ; \text { T46N, } \\
\text { R17W, NMPM }\end{array}$ \\
\hline County & Montrose & Montrose & Montrose & Montrose & Montrose \\
\hline $\begin{array}{l}\text { Lease Tract } \\
\text { Acreage }\end{array}$ & 81 & 325 & 320 & 120 & 813 \\
\hline $\begin{array}{l}\text { Primary Location } \\
\text { of Lease Activities }\end{array}$ & NW1/4, Sec. 22 & $\begin{array}{l}\text { Mine's primary } \\
\text { surface facility } \\
\text { not on tract }\end{array}$ & SE1/4, Sec. 16 & SW1/4, Sec. 16 & $\begin{array}{l}\text { Widely spaced } \\
\text { exploration } \\
\text { activity with no } \\
\text { primary area of } \\
\text { impact }\end{array}$ \\
\hline $\begin{array}{l}\text { Existing } \\
\text { Disturbance } \\
\text { (Acres) }\end{array}$ & 4 & 2 & 193 & $\begin{array}{c}0 \\
\text { (included in figure } \\
\text { for C-JD-7) }\end{array}$ & $<2$ \\
\hline $\begin{array}{l}\text { Historical Lease } \\
\text { Activities }\end{array}$ & $\begin{array}{c}\text { Exploration, } \\
\text { mining }\end{array}$ & $\begin{array}{c}\text { Exploration, } \\
\text { mining }\end{array}$ & $\begin{array}{l}\text { Exploration, } \\
\text { mining }\end{array}$ & Exploration & Exploration \\
\hline \multicolumn{6}{|l|}{ Site Features } \\
\hline $\begin{array}{l}\text { Buildings/ } \\
\text { Structures }\end{array}$ & $x$ & $\begin{array}{c}x \\
\text { (not on tract) }\end{array}$ & $x$ & & \\
\hline $\begin{array}{l}\text { Mine-Rock } \\
\text { Waste Piles }\end{array}$ & $x$ & $x$ & $x$ & $x$ & \\
\hline Adits/lnclines & $x$ & $x$ & $x$ & & \\
\hline Vents & $x$ & $x$ & $x$ & & \\
\hline Shafts & $x$ & & & & \\
\hline Drill Roads & $x$ & $x$ & $x$ & $x$ & $x$ \\
\hline Drill Holes & $x$ & $x$ & $x$ & $x$ & $x$ \\
\hline Petroleum Tanks & $X$ & & & & \\
\hline Retention Ponds & & & $x$ & & \\
\hline \multicolumn{6}{|l|}{ Pre-1974 Sites } \\
\hline Comments & $\begin{array}{l}\text { Drill roads have been } \\
\text { reclaimed. }\end{array}$ & $\begin{array}{l}\text { Mine site is located on } \\
\text { BLM land adjoining } \\
\text { tract; some mining } \\
\text { debris is present. }\end{array}$ & $\begin{array}{l}\text { Extensive drill roads } \\
\text { are present; site } \\
\text { contains open-pit mine } \\
\text { and underground } \\
\text { mine, which is } \\
\text { actively dewatered. }\end{array}$ & $\begin{array}{l}\text { Site contains mine-rock } \\
\text { waste pile for lease } \\
\text { tract } 7 \text {. }\end{array}$ & $\begin{array}{l}\text { Recent exploration has } \\
\text { taken place. All holes, } \\
\text { drill sites, and roads } \\
\text { have been reclaimed. }\end{array}$ \\
\hline
\end{tabular}

NOTE: Sec=Sections; $T=$ Tounship; $R=$ Range; $N=$ North; $W=$ West; NMPM=New Mexico Principle Meridian; $S=S o u t h ; E=E a s t$. 
Table 2 (continued). Summary 0

\begin{tabular}{|c|c|c|c|c|c|c|}
\hline Characteristic & Lease Tract 15A & Lease Tract 17 & Lease Tract 17A & Lease Tract 18 & Lease Tract 19 & 1 \\
\hline $\begin{array}{l}\text { Location of Lease } \\
\text { Tracts }\end{array}$ & $\begin{array}{c}\text { Secs. 22,27; } \\
\text { T44N, R19W, } \\
\text { NMPM }\end{array}$ & $\begin{array}{l}\text { Sec. 14; T45N, } \\
\text { R18W, NMPM }\end{array}$ & $\begin{array}{l}\text { Sec. 15; T45N, } \\
\text { R18W, NMPM }\end{array}$ & $\begin{array}{c}\text { Secs. 21,22,26, } \\
27,28 ; \text { T48N, } \\
\text { R17W, NMPM }\end{array}$ & $\begin{array}{c}\text { Secs. 13,24; } \\
\text { T48N, R18W, } \\
\text { NMPM }\end{array}$ & \\
\hline County & San Miguel & $\begin{array}{l}\text { Montrose and } \\
\text { San Miguel }\end{array}$ & Montrose & Montrose & Montrose & \\
\hline $\begin{array}{l}\text { Lease Tract } \\
\text { Acreage }\end{array}$ & 171 & 283 & 21 & 916 & 702 & \\
\hline $\begin{array}{l}\text { Primary Location } \\
\text { of Lease Activities }\end{array}$ & SE1/4, Sec. 22 & $\begin{array}{l}\text { Widely spaced } \\
\text { exploration } \\
\text { activity with no } \\
\text { primary area of } \\
\text { impact }\end{array}$ & $\begin{array}{l}\text { Widely spaced } \\
\text { exploration } \\
\text { activity with no } \\
\text { primary area of } \\
\text { impact }\end{array}$ & SW1/4, Sec. 22 & SE $1 / 4$, Sec. 24 & \\
\hline $\begin{array}{l}\text { Existing } \\
\text { Disturbance } \\
\text { (Acres) }\end{array}$ & 4 & $<2$ & $<2$ & 4 & 14 & \\
\hline $\begin{array}{l}\text { Historical Lease } \\
\text { Activities }\end{array}$ & $\begin{array}{c}\text { Exploration, } \\
\text { mining }\end{array}$ & Exploration & - Exploration & $\begin{array}{c}\text { Exploration, } \\
\text { mining }\end{array}$ & $\begin{array}{l}\text { Exploration, } \\
\text { mining }\end{array}$ & \\
\hline \multicolumn{7}{|l|}{ Site Features } \\
\hline $\begin{array}{l}\text { Buildings/ } \\
\text { Structures }\end{array}$ & $\begin{array}{c}\mathrm{X} \\
\text { (power line) }\end{array}$ & & & $x$ & $x$ & \\
\hline $\begin{array}{l}\text { Mine-Rock } \\
\text { Waste Piles }\end{array}$ & $x$ & & & $x$ & $x$ & \\
\hline Adits/nclines & $x$ & & & $x$ & $x$ & \\
\hline Vents & & & & $x$ & $x$ & \\
\hline Shafts & $x$ & & & & $x$ & \\
\hline Drill Roads & $x$ & $x$ & $x$ & $x$ & $x$ & \\
\hline Drill Holes & $x$ & $x$ & $x$ & $x$ & $x$ & \\
\hline Petroleum Tanks & & & & $x$ & $x$ & \\
\hline Retention Ponds & & & & $x$ & & \\
\hline Pre-1974 Sites & $x$ & & & & & \\
\hline Comments & $\begin{array}{l}\text { Some pre-1974 mine } \\
\text { debris is present; all } \\
\text { mine sites have been } \\
\text { recently reclaimed. }\end{array}$ & $\begin{array}{l}\text { Minimal disturbance } \\
\text { associated solely with } \\
\text { exploration activities } \\
\text { has occurred. Holes } \\
\text { and drilling areas have } \\
\text { been reclaimed. }\end{array}$ & $\begin{array}{l}\text { Minimal disturbance } \\
\text { associated solely with } \\
\text { exploration activities } \\
\text { has occurred. Holes } \\
\text { and drilling areas have } \\
\text { been reclaimed. }\end{array}$ & $\begin{array}{l}\text { Only mine } \\
\text { development with } \\
\text { minimal production } \\
\text { has occurred. }\end{array}$ & $\begin{array}{l}\text { Mine was productive } \\
\text { for over } 15 \text { years but } \\
\text { the ore reserves are } \\
\text { nearly mined our. }\end{array}$ & $\begin{array}{l}\text { M } \\
\text { as } \\
\text { ex } \\
\text { he }\end{array}$ \\
\hline
\end{tabular}

NOTE: Sec=Sections: $T=$ Township; $R=$ Range; $N=$ North; $W=$ West; MMPM=New Mexico Principle Meridian; $S=S o u t h ; E=E a s t$. 


\begin{tabular}{|c|c|c|c|c|c|}
\hline Lease Tract 19A & Lease Tract 20 & Lease Tract 21 & Lease Tract 22A & Lease Tract 23A & Lease Tract 25 \\
\hline $\begin{array}{c}\text { Secs. 18,19; } \\
\text { T48N, R17W, } \\
\text { NMPM }\end{array}$ & $\begin{array}{l}\text { Sec. 20; T48N, } \\
\text { R17W, NMPM }\end{array}$ & $\begin{array}{c}\text { Secs. 22,27; } \\
\text { T48N, R17W, } \\
\text { NMPM }\end{array}$ & $\begin{array}{c}\text { Secs. } 16,17,20, \\
21 ; \text { T47N, } \\
\text { R17W, NMPM }\end{array}$ & $\begin{array}{l}\text { Sec. 35; T47N, } \\
\text { R17W, NMPM }\end{array}$ & $\begin{array}{c}\text { Secs. 5,6; } \\
\text { T47N, R17W, } \\
\text { NMPM }\end{array}$ \\
\hline Montrose & Montrose & Montrose & Montrose & Montrose & Montrose \\
\hline 1,145 & 579 & 443 & 226 & 47 & 573 \\
\hline $\begin{array}{l}\text { Widely spaced } \\
\text { exploration } \\
\text { activity with no } \\
\text { primary area of } \\
\text { impact }\end{array}$ & $\begin{array}{c}\text { Widely spaced } \\
\text { exploration } \\
\text { activity with no } \\
\text { primary area of } \\
\text { impact }\end{array}$ & SW1/4, Sec. 27 & NW1/4, Sec. 21 & $\begin{array}{l}\text { Widely spaced } \\
\text { exploration } \\
\text { activity with no } \\
\text { primary area of } \\
\text { impact }\end{array}$ & $\begin{array}{c}\text { Mine's primary } \\
\text { surface facility } \\
\text { not on tract }\end{array}$ \\
\hline$<2$ & $<2$ & 3 & 4 & $<2$ & 2 \\
\hline Exploration & Exploration & $\begin{array}{c}\text { Exploration, } \\
\text { mining }\end{array}$ & $\begin{array}{l}\text { Exploration, } \\
\text { mining }\end{array}$ & Exploration & $\begin{array}{c}\text { Exploration, } \\
\text { mining }\end{array}$ \\
\hline & & $x$ & $x$ & . & $\begin{array}{c}x \\
\text { (not on tract) }\end{array}$ \\
\hline & & $x$ & $x$ & & $x$ \\
\hline & & $x$ & $x$ & & $x$ \\
\hline & & $x$ & & & $x$ \\
\hline & & $x$ & & & $x$ \\
\hline$x$ & $x$ & $x$ & $\mathrm{x}$ & $x$ & $x$ \\
\hline$x$ & $\underline{x}$ & $x$ & $x$ & $\underline{x}$ & $x$ \\
\hline & & $x$ & $x$ & & $\mathrm{x}$ \\
\hline & & & $x$ & & $x$ \\
\hline $\begin{array}{l}\text { Minimal disturbance } \\
\text { associated solely with } \\
\text { exploration activities } \\
\text { has occurred. }\end{array}$ & $\begin{array}{l}\text { Minimal disturbance } \\
\text { associated solely with } \\
\text { exploration activities } \\
\text { has occurred. }\end{array}$ & $\begin{array}{l}\text { Extensive under- } \\
\text { ground mining has } \\
\text { occurred; drill roads } \\
\text { are eroding and in } \\
\text { need of repair; refuse } \\
\text { pile is present on site. }\end{array}$ & $\begin{array}{l}\text { Isolated pre-1974 } \\
\text { mine workings occur } \\
\text { on site. }\end{array}$ & $\begin{array}{l}\text { Minimal disturbance } \\
\text { associated solely with } \\
\text { exploration activities } \\
\text { has occurred. }\end{array}$ & $\begin{array}{l}\text { Primary mine site is } \\
\text { not on lease tract; } \\
\text { several pre-1974 } \\
\text { mine sites require } \\
\text { mitigation of safety } \\
\text { hazards. }\end{array}$ \\
\hline
\end{tabular}


- For all proposed surface disturbances, the leaseholder would be required to consult with the Colorado Division of Wildlife, U.S. Fish and Wildlife Service, and/or BLM, as appropriate, to determine whether threatened or endangered (T\&E), or sensitive plant and wildlife species could occur in the area or whether the agencies might have other plant or wildlife concerns in the area. The leaseholder might be required to provide surveys or additional documentation regarding the vegetation or wildlife concern. DOE would not approve the disturbance until agency concerns were resolved.

- For all proposed surface disturbances, the leaseholder would be required to perform a cultural and historical survey of the area to be disturbed. If cultural or historical resources were to occur in the area, the State Historic Preservation Officer would be contacted for a determination of the resource's eligibility for inclusion on the National Register of Historic Places prior to surface disturbance. The leaseholder would be required to prepare a mitigation plan that addresses the protection of the cultural or historic resource. Surface disturbance would not be allowed until the State Historic Preservation Officer and DOE approved the mitigation plan.

- For proposed activities on lease tracts 17 and 17A, DOE would contact BLM to review and approve the proposed activities to ensure that the Dolores River Canyon Wilderness Study Area (WSA) would not be adversely affected. If appropriate, mitigation measures would be applied to the activity.

- For disturbances proposed in potential floodplain or wetland areas, the leaseholder would be required to determine, through consultation with the U.S. Army Corps of Engineers (COE), EPA, and the appropriate State agency, whether a jurisdictional floodplain or wetland was present. The leaseholder might need to propose mitigation measures in a Floodplain/Wetlands Assessment. DOE would review the proposed activity in accordance with 10 CFR 1022 and would approve or disapprove surface disturbance in conjunction with COE, EPA, and the appropriate State agency.

New surface disturbances associated with the three phases of mining are expected to affect an estimated 250 acres (101 hectares) of previously undisturbed land. Approximately 50 percent of this new disturbance would be associated with the placement of mine-rock waste piles. Other new disturbances would be associated with roads, drill pads, small (encompassing less than 5 acres or 2 hectares) surface mines, mine portals, or other surface-plant support facilities.

During the three phases of mine operations, the leaseholder would be required to protect the health and safety of mine workers through implementation of Mine Safety and Health Administration (MSHA) rules and regulations, (codified at 30 CFR 57.5038, 57.5039, and 57.5047) which address protection of the worker from radiological hazards. The leaseholder would be required to ensure that mine workers would not receive an exposure of more than 4 Working-Level Months in any calendar year and that they would not be exposed to air containing concentrations of radon daughters exceeding 1.0 Working Level. In addition, the 
leaseholder would be required to ensure that a worker's individual exposure to gamma radiation would not exceed 5 rems per year. During transport of ore, the leaseholder would be required to ensure that truck drivers' exposure to radiation would not exceed MSHA or DOT (49 CFR 173.425[c][3] and 173.441[b]4) standards, as applicable.

The leaseholder also would be required to protect members of the public from radiation by complying with radiation standards established by the U.S. Nuclear Regulatory Commission (NRC) and EPA. NRC's standard for total effective dose equivalent (TEDE) is 100 millirems per year (mrem/yr) (10 CFR 20). EPA's standard states that "emissions of radon-222 to the ambient air from an underground uranium mine shall not exceed those amounts that would cause any member of the public to receive in any year an effective dose equivalent of $10 \mathrm{mrem} / \mathrm{y}[\mathrm{r}]^{\prime \prime}$ (40 CFR 61.22).

The following subsections describe the lease activities that could occur under the Proposed Action Alternative during the preoperational, operational, and post-operational phases. Depending upon the lease-specific operations, a leaseholder could conduct each phase individually or conduct all three phases simultaneously.

\subsubsection{Preoperational Activities}

Activities that occur before mine development and ore extraction are considered preoperational activities and are grouped into two categories: surface exploration and minesite preparation. Both categories of activities would be primarily short term and could be conducted concurrently. Surface exploration activities would include planning, obtaining access to the lease tracts, constructing roads (if required), performing exploratory drilling, and conducting other types of prospecting activities. Mine-site preparation activities would include planning, building, and improving surface-plant areas.

\subsubsection{Surface Exploration}

Before surface-disturbing activities related to exploration would be conducted, an Exploration Plan would be submitted to DOE for approval.

The Exploration Plan would provide descriptions of

- Areas to be explored, accompanied by maps and/or aerial photos designating existing and proposed access roads.

- Proposed exploration methods.

- Measures to be taken to ensure compliance with the National Environmental Policy Act (NEPA) or other environmental requirements.

- Activities required to reclaim subsequent environmental disturbances. 
The proposed activities outlined in the Exploration Plan would be reviewed by DOE to ensure compliance with NEPA and other environmental regulations. In addition to submitting the Exploration Plan to DOE, the leaseholder would file a Prospecting Notice with the Colorado Mined Land Reclamation Board.

Before transporting drilling equipment to the lease tracts, the leaseholder would be required to obtain access to the lease tracts. BLM typically would administer off-lease access; DOE would administer on-lease access. Both agencies would require that existing roads be used whenever possible. If existing access were unavailable or unsuitable, road construction might be necessary. The leaseholder would consult with either DOE or BLM, depending on whether on-lease or off-lease construction was necessary, to ensure that natural resource concerns and sensitive environmental areas were identified in areas of potential disturbance. The leaseholder also would be required to consult with appropriate State agencies (e.g., Colorado Division of Wildlife or the State Historic Preservation Officer) for natural resource and cultural resource concerns. Rights-of-way (ROWs) and easements would require the leaseholder to mitigate adverse impacts to the environment. During the period of road use, the leaseholder would be obligated to preserve the integrity of previous improvements (e.g., fences, gates, cattle guards, trails, bridges, and water control structures) and to avoid public-land survey monuments. The leaseholder would be required to restore damaged items to their previous condition.

Exploration roads usually would be temporary and generally would be less than 20 feet (6 meters) in width. Surface disturbance would be limited to the minimum area required to obtain a grade and condition that would provide for the safe transportation of drilling equipment to drilling locations. In most cases, disturbance would include removing vegetation and leveling high points in the ROWs. If topsoil or subsoil were excavated, it would be stockpiled for future reclamation. Borrow ditches, crowning, water bars, culverts, side-slope stabilization measures, and riprap would be used to control erosion.

Once access to a drilling location was established, a site approximately 15 by 50 feet ( 4.5 by 15 meters) would be leveled to allow the drill rig to operate. Clearing would be accomplished with as little surface disturbance as possible. Excavation would be required only on extremely unlevel terrain, and topsoil would be stockpiled for future reclamation.

Typically, rotary drill rigs would be used to drill exploratory holes (approximately 6 inches or 15 centimeters in diameter) to as deep as 700 feet (213 meters). The Salt Wash Member of the Morrison Formation would be the primary target horizon. Where the target horizon was shallow (less than 200 feet or 61 meters), smaller drill rigs such as track- or truckmounted wagon drills might be used. Leaseholders would be required to comply with State requirements during the drilling and abandonment of exploratory holes. These requirements, outlined in Mineral Rules and Regulations of the Colorado Mined Land Reclamation Board (Colorado Department of Natural Resources 1995), include procedures for protecting groundwater, avoiding cross-contamination between aquifers, and abandoning drill holes. 
During drilling operations, the leaseholder would be required to take measures to protect natural resources. Drill sites typically would be secured from the public and inadvertent intrusion by wildlife. The leaseholder would be required to equip bulldozers, drill rigs, and other site machinery with fire-suppression equipment and would be required to participate in fire-suppression efforts when feasible.

At the cessation of exploration, access roads and drill pads would be reclaimed unless DOE or BLM, as appropriate, directed otherwise. Abandonment would require recontouring the land to the original grade (or to a condition acceptable to the managing agency), replacing topsoil, reseeding the disturbed areas, and employing erosion control methods.

\subsubsection{Mine-Site Preparation}

DOE would have to approve leaseholder improvements before surface-disturbing activities related to mine-site preparation could be conducted. Improvements would be constructed in accordance with Federal, State, county, and local regulations; construction activities would be accomplished in accordance with MSHA rules and regulations. When suitable reserves were located, a Mining Plan would be developed and submitted to DOE for approval.

The Mining Plan would provide

- A description of roads (including existing and proposed roads), ore reserves, and areas to be affected.

- Maps or aerial photos showing the location of the proposed operations.

- A description of surface-plant areas, mine entries, and operating methods and procedures.

- A description of measures and actions to be taken to comply with NEPA or other environmental regulations and to minimize impact to the environment. Plans for reclamation of environmental disturbances resulting from previous mining activities (i.e., pre-1974 sites) could be required from some leaseholders; reclamation activities would be negotiated with DOE.

- The quantity of water required for conducting mine operations and the location of usable water sources.

The proposed activities outlined in the Mining Plan would be reviewed by DOE to ensure compliance with NEPA and other environmental regulations. In addition to submitting the Mining Plan to DOE, the leaseholder would be required to obtain a permit from the Colorado Mined Land Reclamation Board. 
Off-lease land use might be necessary to support mine operations. If off-lease activities were planned, permits and approvals would be obtained from BLM or the appropriate State agency. ROWs for roads and utilities (i.e., power and communications) would be common off-lease disturbances. Unlike exploration roads, ROWs used for mine operations usually would be improved to enable long-term use. ROWs granted by BLM (or the appropriate State agency) usually would be nonexclusive and would be used by recreationists, grazing permittees, and oil and gas lessees. The leaseholder's off-lease activities would be planned to avoid conflict with other public-land uses; the leaseholder would be required to comply with State and Federal regulations to protect off-lease and natural resource values.

Surface-plant area improvements might include

- Buildings for offices and equipment maintenance

- Telephone and power lines

- Compressors and compressed air lines

- Potable water supply and sanitary facilities (sinks and showers)

- Fuel storage areas

- On-site domestic sewage system

- Trucks and heavy earthmoving equipment

- Electric generator

- Mining equipment (including rock drilling and mine dewatering equipment)

- Explosives storage area

- Ventilation shafts and fans

- Residential housing for security and staff

- Emergency response equipment (for staff safety, environmental damage, and spills)

- Ore stockpiles and loading areas

- Domestic landfill areas (nonhazardous waste)

- Mine-rock waste piles (rock removed from mine to access ore)

- Dewatering evaporation ponds and treatment facilities

- Topsoil stockpile areas

- Vegetation test plots

- Parking lots

Certain improvements and activities would require specific actions on behalf of the leaseholder before operations could begin. Specific actions would include

- Obtaining building permits for utilities, residential structures, offices, and - maintenance sheds. Structures and utilities supporting mine operations (e.g., compressors and electrical equipment) would have to meet local and county building codes and ordinances. 
- Completing a water development plan for development of a potable water supply. A State well-development permit might be required, unless water was obtained from another source, such as a nearby municipal supply. Adjudicated water rights would not be affected by mine operations.

- Obtaining a county-approved septic permit for installation of a sewage system. If a site were unsuitable for a septic system, portable sewage facilities would be required.

- Obtaining Federal or State pollution discharge permits for the control of storm water, for development of dewatering and evaporation ponds, and for discharge of water from ponds to on-site depressions, valleys, or intermittent streambeds.

- Obtaining State permits that might be required for mine emissions to the atmosphere.

- Developing a plan for gas and diesel fuel storage in accordance with State and local regulations. This plan would include a Spill Prevention Control Plan, as required by Federal and State water laws.

- Developing contingency plans for emergencies and releases of hazardous chemicals, substances, pollutants, and wastes.

- Obtaining State permits and preparing a disposal plan for landfill operations if nonhazardous solid waste were to be disposed of on the lease tract.

- Applying fertilizers in accordance with State regulations.

\subsubsection{Operational Activities}

At the conclusion of preoperational activities, operational activities might be initiated. Operational activities may be grouped into two major categories: (1) surface-plant area construction and operation and (2) mine development and operation.

\subsubsection{Surface-Plant Area Construction and Operation}

Leaseholders would construct surface-plant areas to support mining operations. These areas might range in size from 1 to 15 acres (0.4 to 6 hectares) but would average between 3 and 4 acres (1.2 and 1.4 hectares) per mine. Surface-plant areas would include those improvements previously identified in the Mine-Site Preparation subsection of this EA and the following:

\section{Buildings/Utilities}

Buildings constructed on site might vary from offices to storage sheds. These buildings would be constructed in accordance with Federal and State regulations and county ordinances. 
The types of utilities required to service these buildings would be dependent upon the types of operations that would be conducted. Electricity to operate mining equipment, mine lighting, and ventilation fans generally would be supplied through aboveground lines. Generators also might supply electricity to the mines. Air would be supplied to the mines by compressors and delivered through lines of various diameters. Water generally would be hauled to the mine site by truck. Sewage and wastewater would be disposed of through a septic system or at a portable facility.

\section{Service Area}

The service area would be used to service mining vehicles, bulldozers, other heavy equipment, and water trucks. Fuel storage tanks, water tanks, and 55-gallon oil barrels would be located in this area. Leaseholders routinely would conduct inspections of hoses, fuel lines, connections, tank exteriors, and equipment parts stored in the area. Berms and secondary containment for gasoline, solvent, and oil storage facilities would be installed and maintained in accordance with local, State, and Federal regulations. If a petroleum spill or leak requiring notification of Federal and/or State agencies were to occur, the leaseholder would be required to implement the Spill Prevention Control Plan (including containment and cleanup).

\section{Storage}

Chemicals, materials, solvents, oils, degreasers, and other substances used to maintain vehicles would be stored and disposed of in accordance with local, State, and Federal hazardous substance regulations. Material Safety Data Sheets (MSDSs) and emergency equipment (e.g., showers) would be maintained as required by MSHA. If required under Federal or State law, a Contingency Plan would be submitted to the State, EPA, and DOE before the actual storage of such materials on site. The Contingency Plan would outline the types of stored materials for which spills would be reported. Some emergency equipment (e.g., first aid supplies, liquid spill-response supplies, fire extinguishers, etc.) would be maintained on site for accidents involving injuries to employees and/or minimal environmental damages. Additional emergency equipment (e.g., mine rescue equipment) would be maintained on site or at centralized locations that would allow for reasonable response times in accordance with MSHA requirements.

On-site storage of petroleum products and subsequent disposal would comply with State and local regulations. A Spill Prevention Control Plan would be prepared in accordance with Federal and State water laws. Explosives would be stored in accordance with State and Federal regulations and away from areas that contain volatile substances.

\section{Security of Potential Safety Hazard Areas}

Leaseholders would be required to secure and post areas that might be considered hazardous (e.g., ore stockpile areas, loading areas, mine openings, and mine-rock waste piles), in accordance with Federal and State regulations. If necessary, the leaseholder would construct 
fences and other barriers around safety hazard areas to minimize the potential for intrusion by humans and wildlife species and to reduce exposure to radioactive materials.

Mine-Water Discharge/Treatment Ponds

The leaseholder might need to construct mine-water discharge/treatment pond facilities to receive discharge water from underground and open-pit mines. Water would be pumped into discharge ponds from mine sumps constructed in water accumulation areas. If necessary, mine water would be treated to meet applicable discharge standards (i.e., treated with a barium chloride flocculent, passed through a manganese dioxide filter, or treated by another suitable method). Water would then flow to a settling pond, where it would be evaporated and/or discharged to the environment in accordance with a State water discharge permit and National Pollutant Discharge Elimination System requirements. The location of the discharge point would be described to the Colorado Department of Public Health and Environment (CDPHE) Water Quality Control Division, which is charged with permit issuance and enforcement. Maintenance of ponds would include replacing the liners or, if required, reclaiming the ponds after removing the precipitated sediments and liners. Sediments and liners would be disposed of at a State-approved disposal site. Pond inspection would be conducted by CDPHE as part of their review of a leaseholder's discharge permit.

Mine-Rock Waste Piles

Underground and open-pit mining both would require removal of barren and low-grade rock materials to allow access to the economical ore deposits. The removal process would result in large piles of mine-rock waste. The mine-rock waste piles would contain large fractions of coarse rock, much of which would be excavated from areas of little or no mineralization. Consequently, the radium concentration in mine-rock waste would be much lower than the concentration in ore. Rainwater percolating through the coarse rock would not leach significant amounts of radium because of the low liquid-to-solid ratio. Lease stipulations would require leaseholders to construct diversion channels and berms around the mine-rock waste piles to prevent storm-water runoff from entering or leaving the piles.

\section{Nonhazardous Waste}

During mining operations, various types of nonhazardous waste would be generated and disposed of on site in refuse piles or transferred to designated landfills. Nonhazardous waste generated might include empty 55-gallon petroleum barrels, timbers, domestic trash, old mining equipment, and other mining debris. DOE would specify whether the leaseholder could bury waste material on site or must dispose of it off site. Disposal at either location would be in accordance with local, State, and Federal requirements. If permits were required for on-site solid-waste disposal facilities, they would be obtained prior to disposal activities. Waste generated prior to 1974 would be managed as agreed to by DOE and the leaseholder under the terms of future lease agreements. In cases where waste might have archaeological or cultural significance, the State Historic Preservation Officer would be consulted. 


\section{Hazardous Waste}

If hazardous waste were generated during construction and operation, the leaseholder would be required to manage (store and dispose of) the waste in accordance with applicable State and Federal regulations. No disposal of hazardous waste would be allowed on the lease tracts.

\subsubsection{Mine Development and Operation}

Uranium and vanadium ores would be recovered by either underground or open-pit mining methods. Activities common to both mining methods would include accessing the ore deposits, controlling possible pollutants, conducting mine maintenance, hauling ore and waste rock, and transporting ore to mills for processing.

To access ore deposits, overburden consisting of mudstone, shale, and sandstone would be removed first to expose the ore. This mine-rock waste would be removed with conventional heavy equipment. At underground mines, rubber-tired trackless mobile equipment typically would be used to transport mine-rock waste through shafts, adits, or inclines/declines to the mine-rock waste pile outside the mine. At open-pit mines, backhoes, front-end loaders, scrapers, bulldozers, and trucks would be used to move the mine-rock waste to the mine-rock waste piles.

Contaminants from mining operations that could be discharged inadvertently to an underground or surface water source would be controlled to minimize the potential for their release. Because lease activities would not be in close proximity to perennial water sources and because rainfall is extremely limited in this region, the potential for contaminant release into water sources would be minimal. Diversion dams, berms, water bars, silt dams, dikes, and mine-rock waste pile covers would be constructed to divert surface runoff from active areas of mine operations. Historically, water seepage into mine workings has been minor and would be expected to remain minor; however, a few mines (both underground and openpit) might require the leaseholder to pump water into treatment ponds. Methods of controlling water from these mines are discussed in the Mine-Water Discharge/Treatment Ponds subsection.

Materials and equipment used to support mining activities could include bulk explosives, dynamite, and ammonium nitrate. These materials would be stored in approved areas within the underground mine or in an approved shed or building on the surface.

\section{Underground Mines}

As an underground mine was developed and mined, the safety of mine workers and protection of the environment would be of primary concern. The leaseholder would be required to routinely monitor the mine for air quality and noise level. If the air quality were inadequate to ensure the safety of workers, ventilation shafts to the surface or other 
ventilation systems would be constructed. To protect workers from cave-ins, mine walls, backs (ceilings), and other surfaces would be braced with timber sets and other materials.

Only authorized individuals would be allowed to enter mines. Mine entrances would be secured during periods of temporary shutdown and during periods of daily inactivity. The public and wildlife would be discouraged from entry by means of fences, gates, posting, and other barriers.

Mining typically would be accomplished by a random room and pillar method, which involves leaving random pillars of ore and waste in place to support the backs and removing ore material. Two different techniques could be used to mine the ore: the conventional $\mathrm{drill} / \mathrm{blast} / \mathrm{muck}$ technique and the continuous-miner technique.

The conventional technique would use jack-leg drills or other similar devices to drill 2-inch (5-centimeter) diameter, 6- to 10-foot (2 to 4-meter) deep holes in the rock face. The holes would then be filled with explosives, and the explosives would be detonated. The broken material would be removed with shuttle equipment such as load/haul/dumps (commonly referred to as LHDs) and multi-ton haulage trucks or buggies. Split-shooting also might be used in areas with narrow ore seams. In this technique, waste rock would be drilled, blasted, and mucked. The same process would then be used to remove the ore seam. After the ore seam was removed, shotcreting, rockbolting, timbering, or other methods would be used to support the mined-out areas.

The continuous-miner technique would use a machine referred to as a "miner," which removes ore and waste without disturbing the surrounding host rock. The miner would deliver waste rock directly to haulage trucks for removal. As in the conventional technique, shotcreting, rockbolting, timbering, or other methods would then be used to support the mined-out areas.

Once ore was removed from the mine, it would be stockpiled outside the mine for transport to the milling facilities by traditional over-the-road haulage trucks.

During the course of underground mining, water would be needed to perform mining activities. Water would be required for underground drilling to prevent dust from becoming airborne and to remove cuttings from drill bits. Leaseholders could obtain water from a variety of sources, depending upon the particular mine and geographic location. Most underground mines are relatively dry; however, some mines receive seepage from nearby shallow aquifers. This water could be considered as a possible source for several of the mine operations. Other sources might include nearby municipal water supplies, springs, rivers, small ponds, and reservoirs. If water were not available on site, then it would be obtained from the closest source available and hauled to the mine by water trucks. The amount of water needed would depend on the level of mining operation and the number of people working at the site. Permits, if required, would be obtained from the appropriate local, State, or Federal agencies. 
Historically, the following operating conditions were considered appropriate for production of ore on the 22 lease tracts:

- 50 drilling machines in operation

- 35 gallons (133 liters) of water per machine per day

- 26 days of operation per month

NOTE: Quantities of water for domestic use and surface drilling are not included.

Assuming historical amounts of ore would be produced under the Proposed Action Alternative, about 45,500 gallons (172,000 liters) of water would be used monthly, which would be equivalent to the average amount consumed by seven households. Approximately 70 percent of this would be obtained from the mines, and approximately 14,000 gallons (53,000 liters) would be obtained from other sources. Continued use of this quantity of water would not have a noticeable impact on available water resources and would not affect adjudicated water rights.

\section{Surface/Open-Pit Mines}

Small mining operations generally would use a trenching method, which involves the removal of only a small amount of waste rock to expose the ore. The ore would then be removed by conventional techniques. Once the ore was removed, reclamation would consist of backfilling the trench and regrading and recontouring the immediate areas of disturbance.

Larger operations generally would opt for a traditional, benched open pit, in which the depth and size of the ore deposit would dictate the surface dimensions of the pit and benches. Underground mines, which would be used to access ore deposits around the periphery of the main deposit, might be associated with larger open-pit operations. The maintenance required for open-pit mine operations basically would be limited to maintaining the side walls of the pit, which would be subject to slope failure and to erosion from storm-water runoff.

\section{Transportation}

Uranium and vanadium ores produced on the lease tracts would be transported to an existing mill for processing. Two mills might be available for processing ore: the White Mesa Mill near Blanding, Utah, and the Canon City Mill near Canon City, Colorado.

Before transporting ore to the processing mills, the leaseholder would be required to comply with the U.S. Department of Transportation (DOT) hazardous materials regulations codified at 49 CFR 170-180. These regulations require the leaseholder to identify the actions that would be taken in case of an emergency or spill.

Ore could be transported to the mills by truck, truck and pup (trailer), train, or a combination of truck and train. However, the train and truck-and-train methods would not 
be economical during the next 10 years because a railroad loading facility no longer exists in the lease tract areas. In this EA, only the truck and truck-and-pup methods are assessed.

Figure 2 shows the possible haul routes to the processing mills. One primary route accesses the Canon City Mill, and two primary routes-the North Route and the South Route-access the White Mesa Mill.

Hauling ore to the Canon City Mill would require transport through San Miguel, Montrose, Ouray, Gunnison, Chaffee, and Fremont Counties, Colorado. BLM and county roads and State Highways 90 and 141 would serve as collector routes from the lease tracts. These collector routes meet with State Highway 145 about 5 miles ( 8 kilometers) east of Naturita. Haul trucks would proceed southeast along State Highway 145 through Norwood to Placerville, where the haul trucks would travel northeast to Ridgway along State Highway 62. At Ridgway, the haul trucks would proceed north to Montrose along U.S. Highway 550. From Montrose, the haul trucks would turn east onto U.S. Highway 50 and travel through Gunnison, Salida, and Canon City to arrive at the Canon City Mill.

The total distance from the lease tracts to the Canon City Mill would vary between 325 and 400 miles (520 and 650 kilometers), depending upon the point of origin. More than 90 percent of this route is paved and two-lane; four-lane roads exist in and near the cities of Montrose, Gunnison, and Canon City.

Hauling ore along the North Route to the White Mesa Mill would include transport through Montrose and San Miguel Counties, Colorado, and San Juan County, Utah. Collector routes from the lease tracts would include BLM and county roads and State Highways 90 and 141. At the Utah-Colorado border, State Highway 90 changes to Utah State Highway 46 . Haul trucks would proceed west along Utah State Highway 46 through La Sal to the intersection with U.S. Highway 191. At this intersection, the haul trucks would turn south and travel through Monticello and Blanding to arrive at the White Mesa Mill. The mill is approximately 6 miles ( 10 kilometers) south of Blanding. The total distance from the lease tracts to the White Mesa Mill would vary between 100 and 120 miles (160 and 190 kilometers). More than 90 percent of the route is paved with two-lane roads; four-lane roads exist in Monticello and Blanding.

Hauling ore along the South Route to the White Mesa Mill would require transport through Montrose, San Miguel, and Dolores Counties, Colorado, and San Juan County, Utah. The collector routes for the South Route would be the same routes as those used for the North Route. At the intersection of State Highway 141 and U.S. Highway 666 near Dove Creek, the haul trucks would proceed west along U.S. Highway 666 to Monticello, Utah. In Monticello, the haul trucks would turn south onto U.S. Highway 191 and travel through Blanding to the White Mesa Mill. The total distance from the lease tracts to the White Mesa Mill would vary between 70 and 130 miles (110 and 210 kilometers). 


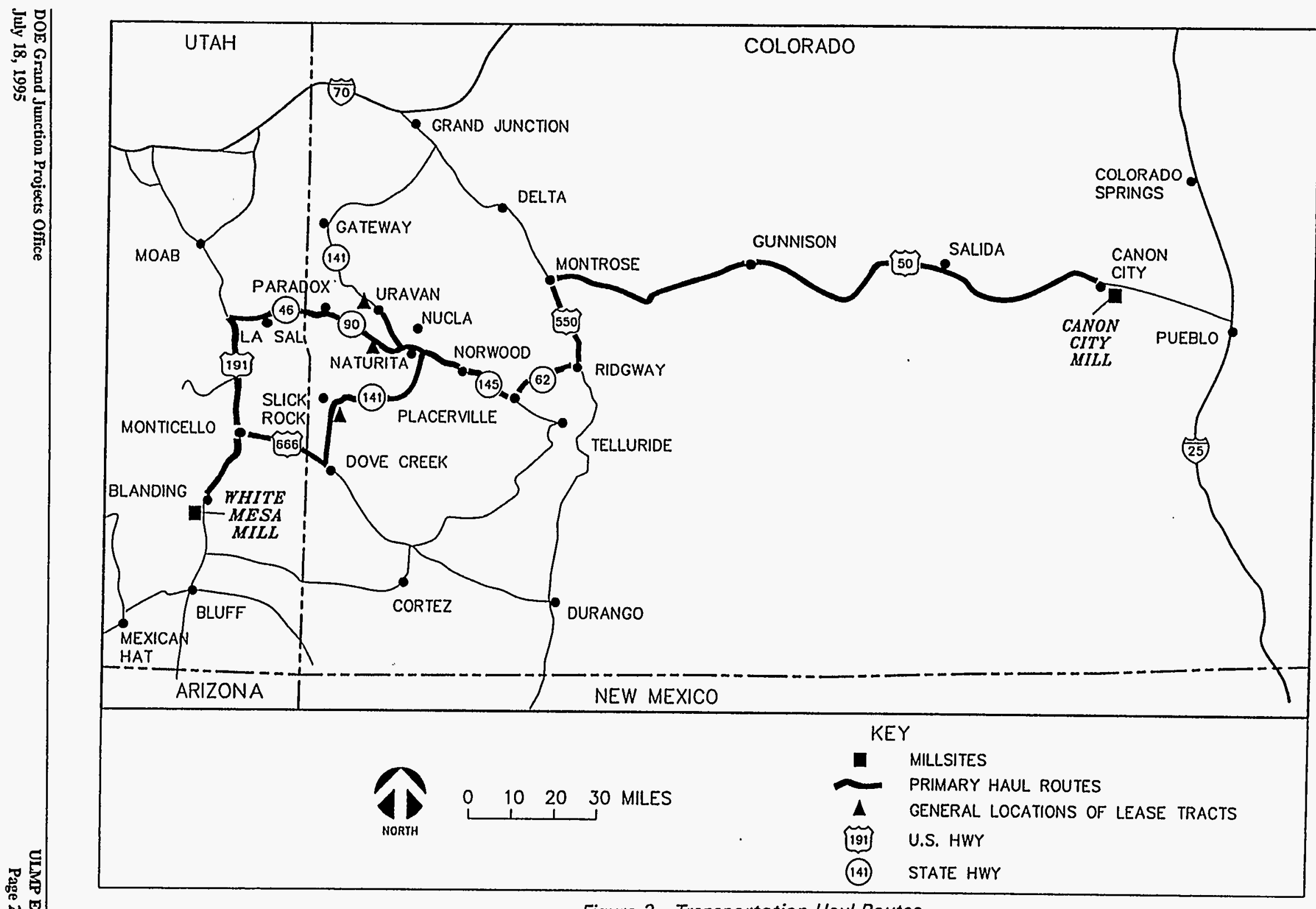

Figure 2. Transportation Haul Routes 
Most leaseholders would transport ore to the White Mesa Mill because of its proximity to the lease tracts. However, depending on mill-feed requirements, leaseholders would retain the right to transport ore to the Canon City Mill when mill feed and economics warrant.

The number of haul trucks transporting ore to the mills is expected to be similar to the number of haul trucks that transported ore from the lease tracts during the 1974-to-1994 period. The average haul rate during periods of production between 1974 and 1994 was 30 trucks per day for all the DOE lease tracts. In 1980, when ore production from the lease tracts was at its peak, the haul rate never exceeded 40 trucks per day. For the purposes of this EA, the average haul rate is projected to be 30 trucks (or truck-and-pup combinations) per day, and on any given day, the number of haul trucks (or truck-and-pup combinations) would not be expected to exceed 40 . Assuming a "worst-case" day of 40 haul trucks, one truck would leave a lease tract approximately every 12 to 15 minutes during an 8-hour day.

\subsubsection{Postoperational Activities}

\subsubsection{Interim Shutdown Activities}

Temporary shutdown of mine operations or an interim period of curtailed operations might be necessary as a result of unforeseen circumstances such as a decrease in market demand for processed uranium or vanadium. However, maintenance to prevent deterioration of facilities would still be required. In this case, DOE, State permitting agencies, and local and county officials would be notified, as appropriate, to determine actions necessary to temporarily secure plant facilities and equipment. Securing plant facilities would include measures necessary to demonstrate due diligence in ensuring preservation of human health, safety, and environmental resources. Interim shutdown activities could include the following:

- Establishing barriers to physical, chemical, and radiological hazardsConditions hazardous to human health, safety, or the environment (including ore stockpiles, waste piles, open pits, mine portals, subsidence holes, and excavated surface depressions) would be fenced and posted or closed (filled) if they were not an integral part of the lease operation and would not be used in the foreseeable future. Mine openings, vents, fans, electric lines, and other support facilities would be maintained to prevent safety hazards.

- Continuing underground mine maintenance-Mines might be actively dewatered and walls might be shored, as necessary, to prevent collapse of the host sedimentary formations inside portals. Air and electrical systems would be maintained in operating condition.

- Controlling fugitive dust-This activity might include seeding disturbed areas with annuals and/or perennials, watering, or applying commercially available dust suppressants. 
- Controlling erosion and storm-water runoff-This activity might include constructing water bars, berms, ditches, or silt fences to control erosion and stormwater runoff.

Temporary closure might be required for access roads that could be needed at a later date. Roads would be reclaimed sufficiently to control dust and storm-water runoff, and barriers would be constructed to prevent access by other land users.

Immediately following temporary closure, those disturbed areas identified by the leaseholder as not being needed for future operational activities would be promptly reclaimed. In addition, inventory items that might deteriorate or that have the potential for creating environmental damage (e.g., first-aid supplies, explosives, batteries, oil, and gas) would be moved off site. Hardware such as nails, pipes, and compressors that were left on site would be secured in place. Liquid or solid materials that were not approved for on-site disposal would be removed from the lease tract and disposed of at permitted facilities.

\subsubsection{Permanent Shutdown Activities}

When mining activities were completed at a location for which there were no future intended lease activities, the leaseholder would be required to initiate reclamation activities in accordance with the approved reclamation plan.

At mine sites, surface-plant improvements would be removed in accordance with DOE and other agency requirements. Debris and waste (hazardous and nonhazardous) (excluding mine-rock waste) would be managed and, if determined necessary by DOE, transported to a permitted landfill for disposal. Pond liners and precipitated sediments would be removed from discharge/treatment ponds, transported, and disposed of at a State-approved facility. Applicable DOT requirements (49 CFR 100-180) would be complied with fully. Hazardous waste would be removed from the lease tracts and transported to a Resource Conservation and Recovery Act-permitted facility. Hazardous materials (those that do not qualify as a waste) would be removed from the lease tracts and disposed of in accordance with applicable State and Federal regulations. Consideration would be given to recycling or returning the material to the manufacturer.

Pond sediments and associated soils containing contaminants inherent in the ore would be managed as radioactive material. Pollutants, contaminants, wastes, or contaminated media that are not inherent to site geology (e.g., gas, oil, and injectates) would be removed from the site and managed as waste under State or Federal regulations.

Reclamation would include recontouring the land to as near the original topography as practicable, replacing topsoil, implementing erosion-control measures, and revegetating disturbed areas with appropriate native and adapted species. Open shafts, adits, and inclines would be closed. Mine-rock waste piles, residual ores, and other radioactive materials inherent to the site would be placed back in the mine or would be graded to 3:1 slopes or less, contoured, covered with topsoil, and seeded in accordance with the reclamation plan. 
In areas where stockpiled topsoil was insufficient, topsoil might be borrowed from other areas of the lease tract or from areas pre-approved by BLM. DOE would monitor reclamation success on an annual basis and would require the leaseholder to correct problems until the reclamation effort met DOE requirements.

The Colorado Division of Wildlife and/or the U.S. Fish and Wildlife Service, as appropriate, would be contacted before reclamation to ensure that wildlife species that might have taken up residence (e.g., bats or birds that are determined sensitive) would not be adversely affected by permanent shutdown activities. Ecosystem concerns associated with wetland areas would be addressed if it were determined that wetlands were created as a result of mining operations.

\subsection{No Action Alternative}

Under the No Action Alternative, DOE would not issue leases on DOE-managed lands, and all mining activities currently being performed on the lease tracts would cease. Reclamation activities would be initiated by former leaseholders immediately following DOE approval of individual reclamation plans. DOE would be responsible for monitoring and evaluating reclamation activities in accordance with the reclamation plan. General reclamation requirements are described in the Permanent Shutdown Activities subsection of the Proposed Action Alternative. Following completion of reclamation activities, DOE would retain the lands in withdrawn status. The responsibility of DOE would then be limited to periodic inspections of the reclaimed sites.

\subsection{ULMP Termination Alternative}

The same actions described under the No Action Alternative would occur under this alternative, with one exception: following completion of reclamation activities, DOE would relinquish the lease tracts to BLM for return to the public domain. 


\subsection{Affected Environment}

This chapter of the EA includes (1) a description of the environmental setting on and near the lease tract areas and (2) specific descriptions of those elements of the environment that may be affected by one or more of the alternatives. Most of the land disturbances associated with the lease tracts occurred in the 1970s and 1980s during the most recent uranium boom. Rather than describing the environment before these disturbances took place, this chapter describes the lease tracts as they exist today. Because this EA is intended to meet the requirements of a programmatic EA, most of the descriptions are not lease-specific but pertain to general site conditions on the DOE-managed lands. Where there are known sensitive resources, however, lease-specific issues are addressed. Site features currently present on the 22 lease tracts are listed in Table 2.

\subsection{Environmental Setting}

The 22 lease tracts are located in the western portions of Montrose and San Miguel Counties in southwestern Colorado (see Figure 1). This semiarid area is characterized by low precipitation and humidity, high evaporation, sunny days, clear nights, and extreme daily temperature changes. Annual precipitation averages 7 to 12 inches (18 to 30 centimeters), and monthly precipitation may range from zero to several inches. Elevations of the mesas and valleys that occur throughout the area vary from 5,500 feet $(1,680$ meters $)$ in the valleys to more than 7,000 feet $(2,140$ meters) on top of the mesas. Prevailing winds are from the southwest at speeds of 3 to 4 miles ( 5 to 6.5 kilometers) per hour; however, wind direction and velocity may vary depending on local topographic features.

The lease tracts are located in three geographical areas within Montrose and San Miguel Counties and are referred to as the Uravan, Paradox Valley, and Slick Rock lease tracts. The group of five tracts referred to as the Uravan lease tracts $(18,19,19 \mathrm{~A}, 20$, and 25) are adjacent to State Highway 141, near the historic community of Uravan in Montrose County, on the tops and side slopes of Spring Creek, Atkinson, and Club Mesas (see Figure 3). Elevations of these tracts range from 5,700 to 6,200 feet (1,700 to 1,900 meters). Two major rivers flow in the valley bottoms below the lease tracts in this region: the Dolores River and its main tributary, the San Miguel River.

In general, the mesas are rimmed and capped by the relatively resistant Dakota Sandstone and Burro Canyon Formations. Side slopes below the rim are formed by the mudstones, shale, and sandstones of the Brushy Basin and Salt Wash Members of the Morrison Formation. The primary ore-bearing formation is the Salt Wash Member of the Morrison Formation, which is composed of fluvial sandstone interbedded with mudstone; extensive mining activity has occurred in this ore-bearing member. The canyon bottom and lower 


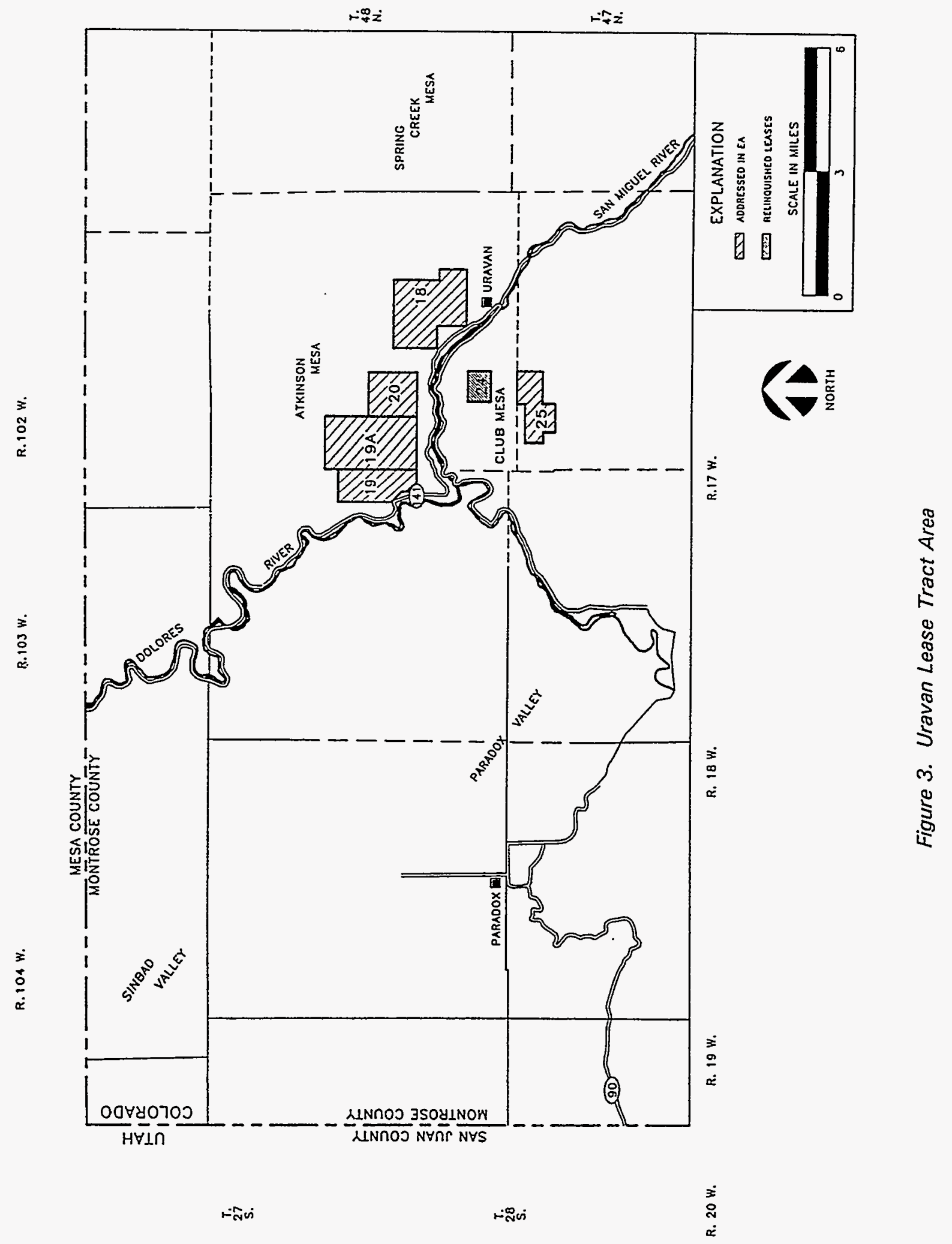


slopes along the Dolores and San Miguel Rivers are formed by fluvial deposits, the Summerville Formation, and the Entrada Sandstone. Below the Entrada Sandstone are sandstones, siltstones, and shales of the Chinle, Wingate, and Kayenta Formations.

A second group of eleven tracts comprise the Paradox Valley lease tracts (see Figure 4) in Montrose and San Miguel Counties. Paradox Valley is a broad valley that is flanked on either side by the high plateaus of Monogram Mesa and Long Park. Elevation of the valley floor is 5,500 to 5,600 feet $(1,680$ to 1,710 meters), which is about 1,000 feet (305 meters) lower than the adjacent mesas. Lease tracts $5,6,7,7 \mathrm{~A}$, and a portion of lease tract 8 are on the steep northeast aspect of Monogram Mesa on the southwest flank of the valley. The remainder of lease tract 8 and all of lease tract 9 are located on the top of Monogram Mesa. Lease tracts 17 and 17A are located further to the southwest on top of Radium Mountain and Wedding Bell Mountain, respectively. Lease tracts $21,22 \mathrm{~A}$, and 23A are on the northeast flank of Paradox Valley on the Long Park plateau.

The steep northeast aspect of Monogram Mesa is formed by a series of structurally complex, faulted slump blocks composed mainly of mudstones, shale, and sandstones of the Brushy Basin and Salt Wash Members of the Morrison Formation. The Burro Canyon Formation and the Dakota Sandstone, which form the caprock of Monogram Mesa, overlie the Morrison Formation. Geology of the Long Park plateau is similar to that of Monogram Mesa, except that the formations dip to the northeast. The lease tracts on the Long Park plateau overlie the Brushy Basin Member of the Morrison Formation.

The third group of six tracts is referred to as the Slick Rock lease tracts and are located near the historic community of Slick Rock in San Miguel County (see Figure 5). In this area, the land surface is deeply incised by the north-flowing Dolores River and its smaller tributary streams. The Dolores River canyon is approximately 500 feet ( 150 meters) wide at the bottom and is characterized by steep slopes and sheer cliffs. Lease tracts $13,13 \mathrm{~A}$, and 14 lie within the canyon or on adjacent ridges. Lease tracts 15 and $15 \mathrm{~A}$ are located west of and above the Dolores River on the first topographic bench. Lease tract 11 lies southwest of Slick Rock on the western flank of Summit Canyon, near the top of Summit Point. Slick Rock lease tract elevations range from 5,700 feet (1,700 meters) along the Dolores River to more than 7,000 feet $(2,100$ meters) on the top of Summit Point.

The floor and lower slopes of the Dolores River canyon are covered with unconsolidated fluvial deposits and alluvial/colluvial deposits, respectively. The sediments on the valley floor are underlain by the Entrada Sandstone. Bedrock formations that form the canyon walls and adjoining mesas include, in ascending order, the Salt Wash and Brushy Basin Members of the Morrison Formation, the Burro Canyon Formation, and the Dakota Sandstone. 


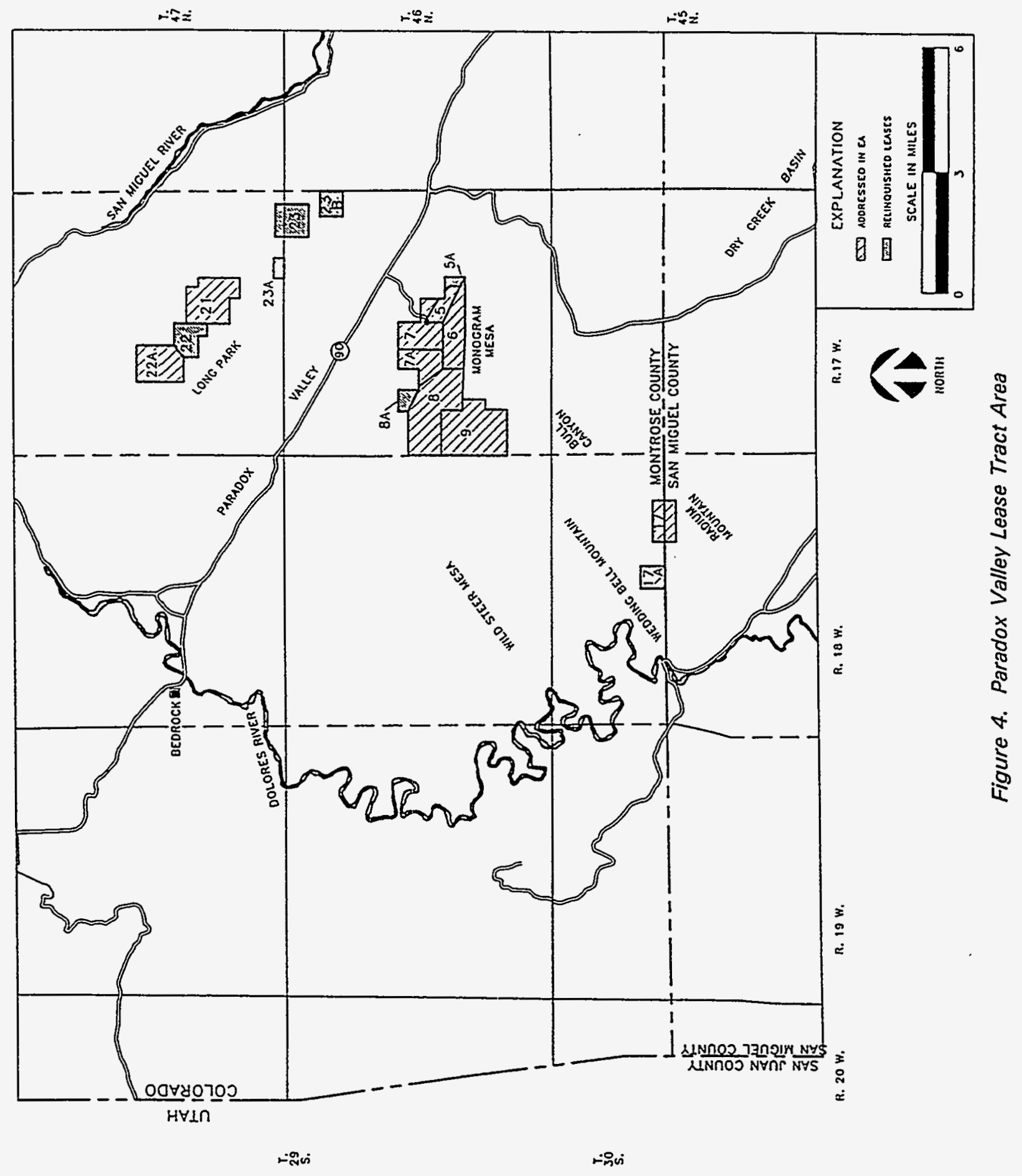




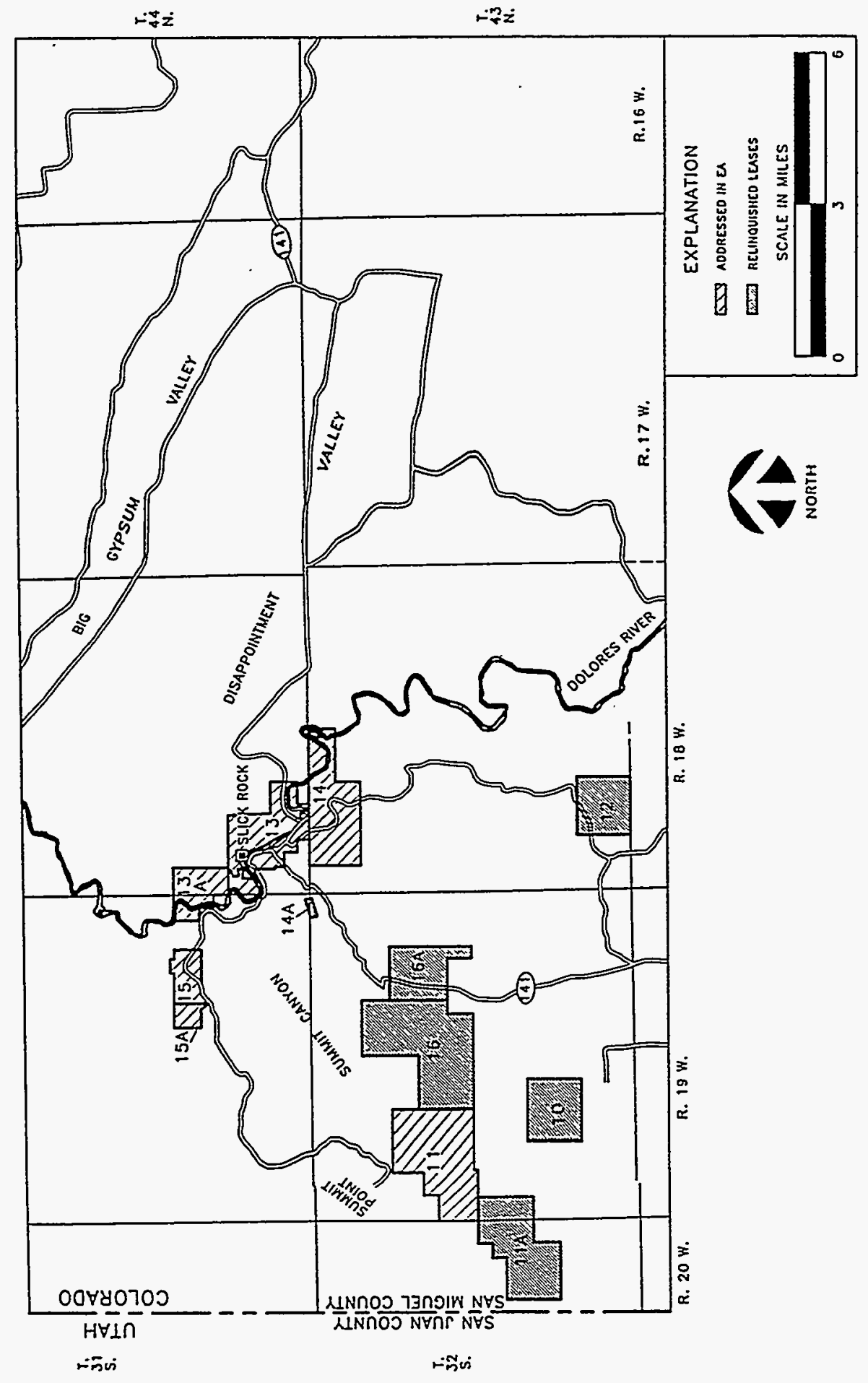

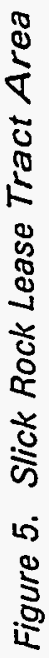




\subsection{Socioeconomics}

\subsubsection{Population}

In 1993, the population of Montrose County was 26,341; approximately 19,425 people reside in Montrose, which is the largest city in this county. The 1998 estimated populations for the county and city are 29,292 and 21,891 , respectively. The population has remained relatively stable during the last decade, fluctuating from a low of 23,868 in 1987 to the present number. Montrose County is experiencing an influx of out-of-state home buyers, resulting in rapid population growth during the last year. This accelerated rate of growth is expected to continue.

In 1993, the population of San Miguel County was 4,453; approximately 2,316 people reside in Telluride, which is the largest town in this county. The 1998 estimated populations for the county and town are 5,042 and 2,732, respectively. The population of San Miguel County has been increasing steadily from a low of 2,959 in 1983.

Populations of Canon City, Colorado, and Blanding, Utah, near the ore processing mills are approximately 14,000 and 3,160, respectively. Canon City is the largest city in Fremont County, which has a population of approximately 32,500 . Blanding is the largest town in San Juan County, which has a population of approximately 12,620. Both communities have experienced a growth in population during the last 10 years.

\subsubsection{Housing}

In 1993, there were a total of 10,198 households in Montrose County and 1,825 households in San Miguel County. A 2.5-percent growth rate is predicted for households in Montrose County, bringing the total number to 11,456 in 1998. San Miguel County is expected to have a higher growth rate ( 6.5 percent), resulting in 2,077 households by 1998 . Total households in Fremont County numbered 11,713 in 1990; total households in San Juan County numbered 4,650 in 1990.

\subsubsection{Employment and Economic Structure}

Both Montrose and San Miguel Counties are experiencing nearly full employment; in July 1994, the unemployment rate was 4.3 percent in Montrose County and 3.8 percent in San Miguel County. These statistics compare favorably with the State unemployment rate of 4.4 percent and the national unemployment rate of 5.9 percent. Both Fremont and San Juan Counties are experiencing higher-than-average unemployment rates. In 1994, the unemployment rate in Fremont County was 6.1 percent. The average unemployment rate in San Juan County during the last 5 years was 8.3 percent.

The largest employer in Montrose and San Miguel Counties is the retail trade industry, which includes the selling of building materials, general merchandise, food, automotive services, and furniture. The mining industry employs fewer than 70 people in Montrose 
County and fewer than 19 in San Miguel County. In Canon City, the largest employers are the Colorado Department of Corrections and the Federal Bureau of Prisons. The uranium and vanadium processing mill employs 28 people. In San Juan County, the largest employers are local, State, and Federal governments; the oil and gas industry; and agriculture.

Currently, approximately 50 workers are employed by the DOE leaseholders to maintain their operations. During periods of production between 1974 and 1994, the average number of workers supporting activities on the lease tracts totaled 300 .

In 1993 , the per capita income for Montrose County was $\$ 11,797$, with households earning a median income of $\$ 24,058$. The per capita income for San Miguel County was $\$ 19,283$, with households earning a median income of $\$ 34,901$. In Fremont County, the per capita income was $\$ 13,270$ in 1992. Of the 63 counties in Colorado, these counties rank 35th, 16th, and 56th, respectively, in per capita income. Per capita income in San Juan County was $\$ 8,194$ in 1990 , which was the lowest in the State of Utah.

\subsection{Transportation}

Numerous unimproved roads constructed on public lands surround the lease tracts. Many of these roads were constructed by the mining and ranching industries before BLM developed regulations for authorizing road construction and use. However, many of these roads are currently maintained by county agencies or BLM.

Two major roadways traverse the lease tract areas: State Highway 141 and State Highway 90 (see Figure 2). State Highway 141 is the primary access to the Uravan and Slick Rock lease tracts, and State Highway 90 is the primary access to the Paradox Valley lease tracts.

The Transportation subsection in Section 3.2.2 describes the haul routes that trucks would take to transport ore from the lease tracts to the processing mills. On the basis of DOT highway statistics, the 1993 fatality and injury rates from accidents along these routes were 0.016 fatalities per million vehicle miles and 0.98 injuries per million vehicle miles (DOT Federal Highway Administration 1994).

Information from the Colorado DOT and Utah DOT indicate that the majority of accidents occur at intersections and on curved sections of the highways. Primary locations of accidents along the haul routes include: (1) intersections on U.S. Highway 50 in Montrose, (2) curved sections of U.S. Highway 50 approximately 10 miles (16 kilometers) east of Montrose, (3) curved sections of U.S. Highway 50 on Monarch Pass, (4) intersections on U.S. Highway 50 within 5 miles (8 kilometers) of Canon City, (5) the intersection of U.S. Highways 191 and 666 in Monticello, and (6) steep, curved sections of State Highways 46 and 90 east of $\mathrm{La} \mathrm{Sal}$, and (7) the 18-mile (30-kilometer) section of U.S. Highway 191 immediately south of Monticello. 
The primary wildlife species that occur along the haul routes that could be affected by traffic include mule deer, elk, porcupines, rabbits, prairie dogs, ground squirrels, golden eagles, and turkey vultures. Small mammals such as rabbits and prairie dogs currently experience the highest mortality rates along the haul routes. Mule deer experience the highest largemammal mortality rate. (NOTE: actual numbers of roadkill are not available). The majority of deer-related accidents occur along the 18-mile (30-kilometer) section of U.S. Highway 191 south of Monticello.

Several perennial water sources occur along the haul routes. The San Miguel River parallels State Highway 141 from Uravan to Naturita, and the Dolores River parallels the highway for several miles near Uravan and Slick Rock. State Highway 90 crosses the Dolores River at Bedrock.

Along the Canon City Mill Route, the San Miguel River parallels State Highway 145 between Norwood and Placerville. The Uncompaghre River parallels U.S. Highway 550 between Ridgway and Montrose, and Ridgway Reservoir parallels the highway for several miles north of Ridgway. Approximately 20 miles ( 30 kilometers) of U.S. Highway 50 parallels the Blue Mesa Reservoir between Montrose and Gunnison. The Arkansas River parallels U.S. Highway 50 for approximately 50 miles (80 kilometers) between Salida and Canon City.

The only perennial surface-water source specific to the North and South Routes is the Recapture Reservoir north of Blanding. U.S. Highway 191 crosses the reservoir dam.

\subsection{Land Use}

Land uses on and around the lease tracts include mining, oil and gas production and exploration, piñon-juniper harvesting, recreation, and agriculture and grazing. All land uses are subject to valid existing rights, which are rights conveyed by title, deed, withdrawal, ROW, permit, or other legally recognized instrument and which have priority over a right granted at a later date. DOE and BLM administer the lands within the lease tract boundaries.

Lands adjacent to and access roads through the lease tracts provide the public with multipleuse opportunities. Sections of the more active lease tracts (e.g., lease tract 7 ) that have been substantially mined have been restricted from unauthorized public access by means of locked gates. BLM has permitted access to the DOE lease tracts through BLM lands by granting ROWs for roads and utilities. However, ROWs typically are not exclusive to the grantor, and all off-lease roads generally are open for public access. BLM also has granted permits to allow leaseholders to use public lands adjacent to the lease tracts for activities associated with lease operations.

Many of the unimproved roads in the vicinity of the lease tracts are used by recreationists for activities such as mountain biking, four-wheel driving, and hunting. They also are used by 
local residents for access to grazing allotments and for general ranching activities. Some of the roads accessing the DOE lease tracts are used for development of oil and gas reserves.

\subsubsection{Mining}

Considerable mineral exploration and development has occurred historically in the vicinity of the lease tracts. Mined minerals have included coal, oil and gas, sand and gravel, uranium, vanadium, gold, silver, copper, lead, zinc, and tungsten. Uranium and vanadium mining and oil and gas development are the predominant mineral activities in the lease tract areas.

Uranium and vanadium reserves occur in the Burro Canyon, Morrison, Entrada, and Chinle Formations within the Uravan Mineral Belt, which extends from Gateway to Slick Rock, Colorado. BLM has estimated that approximately 66,000 unpatented mining claims existed historically in the vicinity of the DOE lease tracts, 62,000 of which were in areas of known or suspected uranium and vanadium mineralization (BLM 1984). BLM estimates that currently there are less than 1,000 active claims in the vicinity of the DOE lease tracts. BLM also estimated that, between 1971 and 1981, approximately 95 to 97 percent of Colorado's mined uranium came from public lands. The DOE lease tracts have produced approximately 6.5 million pounds ( 2.9 million kilograms) of uranium and 33.4 million pounds (15.2 million kilograms) of vanadium during the last 20 years. Of these amounts, 116,000 pounds $(52,600$ kilograms) of uranium and 711,000 pounds $(322,500$ kilograms) of vanadium were produced during 1990; no production has occurred during the last 4 years.

Oil and gas production on public lands near the DOE lease tracts is concentrated in San Miguel County along the Colorado-Utah border. Known oil and gas reserves also are located to the east and south of the Slick Rock lease tracts.

\subsubsection{Recreation}

In the vicinity of the DOE lease tracts, BLM has categorized public lands into two types of recreational management areas: Special Recreation Management Areas (SRMAs) and Extensive Recreation Management Areas (ERMAs). SRMAs are areas where recreation is recognized as the principal land-use management objective. ERMAs are areas where recreation is not the principal objective, but it is considered along with other uses under a multiple land-use management objective.

The Dolores River Canyon SRMA extends from McPhee Reservoir 104 miles (166 kilometers) north to the town of Bedrock. Portions of lease tracts 13, 13A, and 14 lie within the SRMA corridor; however, no mining-associated activity has occurred on these portions. The SRMA includes one of the more popular rafting and canoeing rivers in the southwestern United States. The peak period for river activity is from April 30 to June 15. Recreational sites have been constructed along this SRMA by the U.S. Bureau of Reclamation, U.S. Forest Service, and BLM. 
No ERMAs are located in proximity to the lease tract areas. However, the entire region where the lease tracts are located is recognized for outstanding big-game hunting, four-wheel driving, and mountain biking.

\subsubsection{Timber Harvesting}

Commercial forests (ponderosa pine, Douglas fir, and Engelmann spruce) are very limited in the lease tract area because of the limited rainfall, steep topography, and relatively low elevations. However, the lease tracts and adjoining public lands provide piñon pine and juniper trees for cutting and use as firewood and fence posts.

\subsubsection{Agriculture and Grazing}

No Prime or Unique Farmlands (as defined in 7 CFR 657) exist on the DOE lease tracts. The lease tracts provide minimal forage for domestic livestock and therefore do not support concentrated grazing. BLM has estimated that 30 to 50 acres (12 to 20 hectares) of forage compose one animal unit month (AUM) (Hurshman 1994). BLM also has stated that grazing allotment boundaries may be within the DOE lease tract boundaries (Hurshman and Lewis 1994). Portions of the Uravan and Paradox Valley lease tracts are within areas designated by BLM as Livestock Management Areas. None of the Slick Rock lease tracts occur within Livestock Management Areas.

\subsection{Air Quality}

The area encompassing the DOE lease tracts is designated a Prevention of Significant Deterioration Class II attainment area by the State of Colorado. The State's air-quality classification system establishes amounts by which the ambient air quality of an area may be degraded from existing baseline conditions; Class $I$ is the most restrictive, and Class III is the least restrictive. The baseline ambient air quality on the lease tracts meets all Federal air-quality standards.

\subsection{Groundwater}

The Uravan lease tracts are directly underlain, in descending order, by the Dakota Sandstone, Burro Canyon Formation, Morrison Formation, Summerville Formation, and Entrada Sandstone. Ore is mined from the Salt Wash Member of the Morrison Formation. Because of low precipitation and recharge rates, little groundwater is expected within the Dakota Sandstone or Burro Canyon and Morrison Formations. The shallowest significant groundwater is expected to be present in the Entrada Sandstone, which is separated from the ore-bearing Salt Wash Member by the low-permeability Summerville Formation.

A similar hydrogeologic setting occurs in the area of the Paradox Valley lease tracts. The shallowest significant groundwater is present in the Entrada Sandstone, which is 
stratigraphically below and separated from the overlying ore-bearing formation by the shales and fine-grained sandstones of the Summerville Formation. Above the ore-bearing formation is the Brushy Basin Member of the Morrison Formation, which also behaves as an aquitard. This formation reduces the amount of direct recharge to the underlying sands of the Salt Wash Member and the Entrada Sandstone. The high frequency of faulting and slumping in the area of lease tracts $5,6,7,7 \mathrm{~A}$, and the eastern portion of lease tract 8 has resulted in the downward displacement of the Morrison Formation and has, in effect, isolated this area hydrologically. Where fluvial sands overlie impermeable mudstones and shale within this slumped area, perched groundwater may occur. Small amounts of water have been reported to occur within the Burro Canyon Formation and the Dakota Sandstone. Downward migration of this groundwater will be slowed and perhaps redirected by the Brushy Basin aquitard. Evidence of this may be seen near the mine portal on lease tract 9 where a surface seep appears to flow from the surface contact of the Burro Canyon Formation and the Brushy Basin Member of the Morrison Formation.

Groundwater in the area of the existing mine on lease tract 7 has elevated concentrations of radioactive elements, total dissolved solids (TDS), and sulfate. This elevated radioactivity is attributed to ore occurrence in the sandstone beds of the Salt Wash Member of the Morrison Formation. The high levels of TDS and sulfate suggest that local groundwater does not receive any appreciable recharge (Cotter Corporation 1979).

The Slick Rock lease tracts are underlain by the Dakota Sandstone, Burro Canyon. Formation, and Brushy Basin and Salt Wash Members of the Morrison Formation. No significant groundwater resources are expected to occur in these units because of low precipitation and recharge rates, presence of structural and topographic discontinuities, and presence of interbedded and impermeable units.

\subsection{Surface Water}

The major rivers in the Uravan lease tract area are the Dolores River and its largest tributary, the San Miguel River. Neither river is contiguous with the lease tracts. Only ephemeral streams, which flow in response to precipitation events, occur on the lease tracts. These ephemeral drainages may contribute flow to the Dolores and San Miguel Rivers during precipitation events.

Both the Dolores and San Miguel Rivers exhibit large seasonal fluctuations in flow, with high runoff in spring and low flow after midsummer. The flow of the Dolores River is regulated mainly by McPhee Dam and upstream irrigation diversions. The average flow of the San Miguel River at Uravan, 4 miles (6.5 kilometers) above the confluence with the Dolores River, is estimated at 107,500 acre-feet (132 million cubic meters) annually (U.S. Bureau of Reclamation 1978). 
The water quality of the rivers varies considerably on a seasonal basis because of fluctuations in runoff and in the volume of brine groundwater entering the Dolores River as it passes through Paradox Valley. The concentration of TDS in the Dolores River just above the confluence with the San Miguel River, from 1971 to 1976, was greater than 12,000 milligrams per liter (mg/L); the primary constituents included sodium, chloride, sulfate, potassium, magnesium, calcium, and bicarbonate (U.S. Bureau of Reclamation 1978). Below the confluence, the salinity of the Dolores River decreases considerably during periods of low flow because of the inflow of comparatively fresh water from the San Miguel River.

The surface water system in the area of Paradox Valley lease tracts 5, 6, 7, 7A, 8, and 9 consists of several ephemeral streams that flow only during wet periods of the year and after unusually heavy rains. Runoff from the local watershed along the northeast flank of Monogram Mesa drains toward East Paradox Creek and also recharges the alluvial aquifer within Paradox Valley. Surface runoff in the Long Park plateau area flows to the northeast, in existing drainages, toward the San Miguel River. Surface water originating from lease tract 9 on the southwestern edge of Monogram Mesa flows into tributaries of Bull Canyon, as does runoff from lease tracts 17 and 17A on Radium and Wedding Bell Mountains. Because of the semiarid conditions present in the Paradox Valley area, significant surfacewater flows in ephemeral streams do not occur, and it is unlikely that ephemeral-stream flow ever reaches an active stream.

The only significant surface-water source in the vicinity of the Slick Rock lease tracts is the Dolores River, which is contiguous with lease tracts 13,13A, and 14. The flow of the Dolores River in this area is regulated primarily by McPhee Dam, located approximately 46 miles (74 kilometers) upstream. Flow also is affected by numerous upstream irrigation diversions. Several upstream tributaries, including Disappointment Creek, contribute high volumes of snowmelt runoff to the Dolores River during late spring, resulting in maximum flow rates that can exceed 5,500 cubic feet per second (156 cubic meters per second) (Jacobs Engineering Group Inc. 1994a). Numerous ephemeral drainages occur on the lease tracts and may contribute flow to the Dolores River during summer thunderstorms and spring snowmelt.

In the area of the Slick Rock lease tracts, the Dolores River has been classified as suitable for domestic water supply and agricultural purposes by CDPHE; however, withdrawals of water from the river for these purposes are minimal. In addition, CDPHE has rated the Dolores River as Class 1 recreational waters (e.g., suitable for rafting) and as Class 1 for cold-water aquatic life (Colorado Department of Health 1986).

\subsection{Soils}

Lease-specific soils information is available from the Montrose BLM District Office. In general, soils throughout the three DOE lease tract areas vary in relation to the underlying bedrock types. Soils on the tops of mesas underlain by sandstones are sandy and loamy; 
those on mesa side-slopes underlain by shale, mudstones, and sandstones vary from sandy to clayey; and those along floodplains are sandy and silty. The potential for wind and water erosion of soils on mesa tops and floodplains is moderate; however, the potential for soil erosion on mesa side slopes is severe.

BLM designates the side slopes in Paradox Valley as Erosion Management Areas because of their inherently high erosion rates (BLM 1984). All the Paradox Valley lease tracts are within or border these areas, with the exception of lease tracts 17 and 17A. No Erosion Management Areas are identified in the Uravan or Slick Rock lease tract areas.

\subsection{Vegetation}

Sagebrush-grass and piñon-juniper plant communities dominate the terrain throughout the lease tract areas. Table A-1 in Appendix A lists the common and scientific names of plants that occur on or near the lease tracts. Higher elevations support species associated with the sagebrush-grass and piñon-juniper plant communities, such as single-leaf ash, fringed sagewort, Utah serviceberry, mountain mahogany, antelope bitterbrush, mormon tea, forestiera, Gambel's oak, skunkbush sumac, grassy rockgoldenrod, green needlegrass, needleandthread, slender wheatgrass, and saline wildrye. Lower elevations and drier sites support species such as fourwing saltbush, winterfat, bud sagebrush, saltbush, hairy goldenaster, milkvetch, hairspine pricklypear, greasewood, skeletonplant, buckwheat, Spanish bayonet, Colorado four o'clock, scarlet globemallow, primrose, Indian ricegrass, galleta grass, blue grama, alkali sacaton, Sandberg bluegrass, bottlebrush squirreltail, sand dropseed, and western wheatgrass. Two lease tracts ( 8 and 23A) have moister microclimates (niches where water is more abundant) and accommodate ponderosa pines.

Cryptobiotic soil crusts, which consist of cyanobacteria, lichens, and mosses, are an important component of the cold desert ecosystems of the Colorado Plateau. These crusts enhance soil stability, reduce water runoff, increase soil nutrient content, and enhance seed germination and the establishment of plants (Belnap 1992). Although the lease tracts have not been surveyed for cryptobiotic soil crusts, undisturbed areas throughout the lease tract areas are expected to support extensive cryptobiotic growth.

In disturbed areas, rubber rabbitbrush, green rabbitbrush, broom snakeweed, curlycup gumweed, and cheatgrass abound; however, native species such as fourwing saltbush, big sagebrush, piñon, and Utah juniper are increasing in some of these areas. Many unreclaimed sites support invader or weedy species such as halogeton, common sunflower, prickly lettuce, prickly Russian thistle, tall tumblemustard, curly dock, common kochia, bobtail barley, and pepperweed whitetop. One noxious weed (as defined by the State of Colorado), Russian knapweed, is found throughout much of the area.

Two Paradox Valley lease tracts (7 and 9) have small areas of vegetation that are characteristic of a wetlands ecosystem. Discharge water from containment ponds supports 
vegetation that includes broadleaf cattails, Fremont's cottonwoods, western wheatgrass, saltcedar, bobtail barley, annual rabbitsfoot grass, and reed canarygrass.

The Dolores River flows through Slick Rock lease tracts 13,13A, and 14. Vegetation that is characteristic of wetlands is found on lease tract 14 in small, shallow surface-mine depressions that collect and trap storm water. Although vegetation surveys have not been conducted in areas adjacent to the river, it is expected that these areas are dominated by willows, saltcedar, and Russian olive. Stands of Fremont's cottonwood and associated riparian and wetland vegetation also are likely to occur.

T\&E plant species are not known to exist near any of the lease tracts. However, four plant species, listed as candidate or sensitive species, might occur on the lease tracts. These species include the Wetherill's milkvetch, found in west-central Colorado in mountain brush and piñon-juniper plant communities from 4,700 to 5,800 feet $(1,400$ to 1,800 meters); the kachina fleabane, found in seeps, hanging gardens, and open slick-rock in Montrose County between 5,345 and 8,400 feet (1,625 to 2,550 meters); the Dolores River skeletonplant, found in alluvial soils in piñon-juniper plant communities between 4,500 to 4,700 feet (1,370 to 1,400 meters); and the Paradox lupine, found in washes and draws with clayey soils in piñon-juniper plant communities between 5,000 and 5,800 feet $(1,500$ to 1,800 meters) (U.S. Forest Service et al. 1991). Naturita milkvetch, a BLM-identified sensitive species, also may be found on the lease tracts.

\subsection{Wildlife}

Wildlife expected to be found in the areas of the DOE lease tracts is typical of that found in the Colorado Plateau region. Table A-2 in Appendix A lists the species that are likely to be found on the lease tracts. General information on wildlife in the region is published in the San Juan/San Miguel Resource Management Plan and Environmental Impact Statement (BLM 1984) and the Mesa Creek Coordinated Resource Management Plan (BLM 1993).

Several species that could occur on the lease tracts are of special concern because their habitat could be affected by uranium mining activities. These species include mule deer, elk, pronghorn antelope, desert bighorn sheep, bats, and neotropical migratory birds.

Mule Deer-Several of the lease tracts fall within important mule-deer winter habitat. Atkinson and Spring Creek Mesas (lease tracts 18, 19, 19A, and 20) are the primary mule-deer wintering areas for the west side of the Uncompahgre Plateau. Other major wintering areas include Disappointment Valley (lease tracts 13, 13A, and 14), Paradox Valley (lease tracts 21, 22A, and 23A), and Monogram Mesa (lease tracts 5, 6, 7, 7A, 8, and 9) (Welch 1994).

Elk-Disappointment Valley, which includes lease tracts 13, 13A, and 14, is a major winter concentration area for elk populations (Welch 1994). 
Pronghorn Antelope-A small band of pronghorn antelope remains in the Dry Creek Basin and Disappointment Valley areas after reintroduction efforts by the Colorado Division of Wildlife. These animals could occur on lease tracts 13,13A, and 14.

Bats-Lease tracts 5, 6, 7, 9, 11, 13, 13A, 15, 18, 19, 21, 22A, and 25 have mine shafts, adits, and inclines/declines that could provide roosting habitat for bats. No evidence of bat habitation has been found at these lease tracts. However, the Colorado Division of Wildlife and BLM (Navo 1995, Ingersol 1994) have observed the spotted bat, western big-eared bat, fringed myotis, long-eared myotis, long-legged myotis, small-footed myotis, California myotis, and Yuma myotis, all of which are candidates for protection under the Endangered Species Act, in abandoned uranium mines in Colorado.

Desert Bighorn Sheep-The Colorado Division of Wildlife has successfully reintroduced desert bighorn sheep along the Dolores River near Slick Rock. Lease tracts 13, 13A, and 14 are likely to be visited by these sheep.

Neotropical Migratory Birds-Neotropical migratory birds depend on continuous and healthy riparian vegetation for migration corridors and nesting habitat. Several of these species (including the lazuli bunting and several species of warblers, vireos, and flycatchers) are expected to occur on or near the lease tracts that support riparian vegetation. The southwestern willow flycatcher is Federally listed as an endangered species.

Table 3 lists the T\&E species that could occur within Montrose and San Miguel Counties (Rose 1993). The Montrose District BLM was consulted to determine which of these species might occur on specific lease tracts. These species are identified in Table 3.

\subsection{Cultural/Historical Resources}

Ten thousand to 12,000 years of human use or occupation in western Colorado's plateau country has been documented (BLM 1984). Evidence of the earliest people-the big-game (mammoth) hunters of the Paleo-Indian tradition (10000 to 5500 B.C.)-is rarely encountered in the region. The presence of the Paleo-Indian in western Colorado is inferred from archaeological finds of distinctive projectile- point styles associated with the Llano or Clovis complex (dated between 10000 and 9000 B.C.) and the Folsom complex (dated between 9000 and 7000 B.C.) and from finds of projectile points and lithic sites associated with the Plano complex (dated between 7000 and 5500 B.C.) (Chandler et al. 1990).

Around 5500 B.C., the moderation of climatic conditions forced a change in human subsistence. The emphasis on big-game hunting gave way to the exploitation of a greater variety of animal and plant foodstuffs and the emergence of what is known as the Archaic tradition. The Archaic tradition is well represented in western Colorado. 
Table 3. Threatened and Endangered Species That Could Occur on DOE Lease Tracts

\begin{tabular}{|c|c|c|c|}
\hline $\begin{array}{l}\text { Common } \\
\text { Name }\end{array}$ & $\begin{array}{l}\text { Scientific } \\
\text { Name }\end{array}$ & Status & Occurrence on Lease Tracts \\
\hline $\begin{array}{l}\text { Black-footed } \\
\text { ferret }\end{array}$ & $\begin{array}{l}\text { Mustela } \\
\text { nigripes }\end{array}$ & Endangered & $\begin{array}{l}\text { Black-footed ferrets could, but are not known to, occur on } \\
\text { any of the lease tracts. However, some of the lease tracts } \\
\text { could support prairie-dog towns that might meet the criteria } \\
\text { for ferret habitat. The lease tracts have not been surveyed } \\
\text { for prairie-dog towns. }\end{array}$ \\
\hline $\begin{array}{l}\text { Peregrine } \\
\text { falcon }\end{array}$ & $\begin{array}{l}\text { Falco } \\
\text { peregrinus }\end{array}$ & Endangered & $\begin{array}{l}\text { Peregrine falcons could, but are not known to, inhabit any of } \\
\text { the lease tracts. A peregrine nest is located northwest of } \\
\text { lease tract } 25 \text {. This nest is too far from the lease tract to be } \\
\text { of concern (Welch 1994). }\end{array}$ \\
\hline Bald eagle & $\begin{array}{l}\text { Haliaeetus } \\
\text { leucocephalus }\end{array}$ & Endangered & $\begin{array}{l}\text { Bald eagles winter in riparian habitat along the Dolores River } \\
\text { and in Dry Creek Basin. A winter nocturnal roost area is } \\
\text { located in Disappointment Valley. Eagles probably forage for } \\
\text { carrion in deer and elk winter-concentration areas such as } \\
\text { Atkinson Mesa (lease tracts } 18,19,19 \mathrm{~A} \text { and } 20 \text { ), } \\
\text { Disappointment Valley (lease tracts } 13,13 \mathrm{~A} \text {, and } 14 \text { ), } \\
\text { Paradox Valley (lease tracts } 21,22 \mathrm{~A}, \text { and } 23 \mathrm{~A} \text { ), and } \\
\text { Monogram Mesa (lease tracts } 5,6,7,7 \mathrm{~A}, 8 \text {, and } 9 \text { ). }\end{array}$ \\
\hline $\begin{array}{l}\text { Colorado } \\
\text { squawfish }\end{array}$ & $\begin{array}{l}\text { Ptychocheilus } \\
\text { lucius }\end{array}$ & Endangered & $\begin{array}{l}\text { The Colorado squawfish does not occur on any of the lease } \\
\text { tracts; however, it could inhabit the Dolores River, which } \\
\text { flows through lease tracts } 13 A, 13 \text {, and } 14 \text {. }\end{array}$ \\
\hline $\begin{array}{l}\text { Razorback } \\
\text { sucker }\end{array}$ & $\begin{array}{l}\text { Xyrauchen } \\
\text { texanus }\end{array}$ & Endangered & $\begin{array}{l}\text { The razorback sucker does not occur on any of the lease } \\
\text { tracts; however, it could inhabit the Dolores River, which } \\
\text { flows through lease tracts } 13 \mathrm{~A}, 13 \text {, and } 14 \text {. }\end{array}$ \\
\hline $\begin{array}{l}\text { Humpback } \\
\text { chub }\end{array}$ & Gila cypha & Endangered & $\begin{array}{l}\text { The humpback chub does not occur on any of the lease } \\
\text { tracts; however, it could inhabit the Dolores River, which } \\
\text { flows through lease tracts } 13 \mathrm{~A}, 13 \text {, and } 14 \text {. }\end{array}$ \\
\hline Bonytail chub & Gila elegans & Endangered & $\begin{array}{l}\text { The bonytail chub does not occur on any of the lease tracts; } \\
\text { however, it could inhabit the Dolores River, which flows } \\
\text { through lease tracts } 13 \mathrm{~A}, 13 \text {, and } 14 \text {. }\end{array}$ \\
\hline $\begin{array}{l}\text { Mexican } \\
\text { spotted owl }\end{array}$ & $\begin{array}{l}\text { Strix } \\
\text { occidentalis } \\
\text { lucida }\end{array}$ & Threatened & $\begin{array}{l}\text { Mexican spotted owis are not known to inhabit any of the } \\
\text { lease tracts. }\end{array}$ \\
\hline $\begin{array}{l}\text { Southwestern } \\
\text { willow } \\
\text { flycatcher }\end{array}$ & $\begin{array}{l}\text { Empidomax } \\
\text { trailii extimus }\end{array}$ & Endangered & $\begin{array}{l}\text { Southwestern willow flycatchers could occur in riparian areas } \\
\text { on or near any of the lease tracts. }\end{array}$ \\
\hline Spotted bat & $\begin{array}{l}\text { Euderma } \\
\text { maculatum }\end{array}$ & Candidate & $\begin{array}{l}\text { Spotted bats are likely to occur on lease tracts that contain } \\
\text { sandstone cliffs and outcroppings. Because spotted bats are } \\
\text { crevice-roosters rather than cave-roosters, it is unlikely that } \\
\text { they would occupy any of the mine shafts, adits, or } \\
\text { inclines/declines on the tracts. }\end{array}$ \\
\hline $\begin{array}{l}\text { Fringed } \\
\text { Myotis }\end{array}$ & $\begin{array}{l}\text { Myotis } \\
\text { thysanodes }\end{array}$ & Candidate & $\begin{array}{l}\text { The fringed myotis, although not specifically documented on } \\
\text { the lease tracts, is known to use uranium mines in Colorado. }\end{array}$ \\
\hline $\begin{array}{l}\text { Western } \\
\text { big-eared bat }\end{array}$ & $\begin{array}{l}\text { Plecotus } \\
\text { townsendii }\end{array}$ & Candidate & $\begin{array}{l}\text { The western big-eared bat, although not specifically } \\
\text { documented on the lease tracts, is known to use uranium } \\
\text { mines in Colorado. }\end{array}$ \\
\hline $\begin{array}{l}\text { California } \\
\text { myotis }\end{array}$ & $\begin{array}{l}\text { Myotis } \\
\text { Californicus }\end{array}$ & Candidate & $\begin{array}{l}\text { The California myotis, although not specifically documented } \\
\text { on the lease tracts, is known to use uranium mines in } \\
\text { Colorado. }\end{array}$ \\
\hline $\begin{array}{l}\text { Allen's big- } \\
\text { eared bat }\end{array}$ & $\begin{array}{l}\text { Idionyoteris } \\
\text { phyllotus }\end{array}$ & Candidate & $\begin{array}{l}\text { Allen's big-eared bat, although not specifically documented } \\
\text { on the lease tracts, is known to use uranium mines in } \\
\text { Colorado. }\end{array}$ \\
\hline
\end{tabular}


Table 3 (continued). Threatened and Endangered Species that Could Occur on DOE Lease Tracts

\begin{tabular}{|c|c|c|c|}
\hline $\begin{array}{l}\text { Common } \\
\text { Name }\end{array}$ & $\begin{array}{l}\text { Scientific } \\
\text { Name }\end{array}$ & Status & Occurrence on Lease Tracts \\
\hline $\begin{array}{l}\text { Long-eared } \\
\text { myotis }\end{array}$ & Myotis evotis & Candidate & $\begin{array}{l}\text { The long-eared myotis, although not specifically } \\
\text { documented on the lease tracts, is known to use uranium } \\
\text { mines in Colorado. }\end{array}$ \\
\hline $\begin{array}{l}\text { Long-legged } \\
\text { myotis }\end{array}$ & Myotis volans & Candidate & $\begin{array}{l}\text { The long-legged myotis, although not specifically } \\
\text { documented on the lease tracts, is known to use uranium } \\
\text { mines in Colorado. }\end{array}$ \\
\hline $\begin{array}{l}\text { Small-footed } \\
\text { myotis }\end{array}$ & $\begin{array}{l}\text { Myotis } \\
\text { ciliolabrum }\end{array}$ & Candidate & $\begin{array}{l}\text { The small-footed myotis, although not specifically } \\
\text { documented on the lease tracts, is known to use uranium } \\
\text { mines in Colorado. }\end{array}$ \\
\hline $\begin{array}{l}\text { Yuma } \\
\text { myotis }\end{array}$ & $\begin{array}{l}\text { Myotis } \\
\text { yumanensis }\end{array}$ & Candidate & $\begin{array}{l}\text { The Yuma myotis, although not specifically documented on } \\
\text { the lease tracts, is known to use uranium mines in Colorado. }\end{array}$ \\
\hline $\begin{array}{l}\text { Southwest } \\
\text { otter }\end{array}$ & $\begin{array}{l}\text { Lutra } \\
\text { canadensis } \\
\text { sonorae }\end{array}$ & Candidate & $\begin{array}{l}\text { The southwest otter does not inhabit the reaches of the } \\
\text { Dolores River that are near any of the lease tracts. }\end{array}$ \\
\hline $\begin{array}{l}\text { Loggerhead } \\
\text { shrike }\end{array}$ & $\begin{array}{l}\text { Lanius } \\
\text { ludovicianus }\end{array}$ & Candidate & $\begin{array}{l}\text { Loggerhead shrikes could occur in riparian areas and oak } \\
\text { brush stands on any of the lease tracts. }\end{array}$ \\
\hline $\begin{array}{l}\text { White-faced } \\
\text { ibis }\end{array}$ & Plegadis chihi & Candidate & $\begin{array}{l}\text { White-faced ibis are not known to inhabit any of the lease } \\
\text { tracts. }\end{array}$ \\
\hline $\begin{array}{l}\text { Ferruginous } \\
\text { hawk }\end{array}$ & Buteo regalis & Candidate & $\begin{array}{l}\text { Ferruginous hawks are not known to inhabit any of the lease } \\
\text { tracts. }\end{array}$ \\
\hline $\begin{array}{l}\text { Great Basin } \\
\text { silverspot } \\
\text { butterfly }\end{array}$ & $\begin{array}{l}\text { Speyeria } \\
\text { nokomis }\end{array}$ & Candidate & $\begin{array}{l}\text { Great Basin silverspot butterflies are not known to inhabit } \\
\text { any of the lease tracts. }\end{array}$ \\
\hline $\begin{array}{l}\text { Flannel- } \\
\text { mouth } \\
\text { sucker }\end{array}$ & $\begin{array}{l}\text { Catostomus } \\
\text { latipinnis }\end{array}$ & Candidate & $\begin{array}{l}\text { The flannelmouth sucker does not occur on any of the lease } \\
\text { tracts; however, it could inhabit the Dolores River, which } \\
\text { flows through lease tracts } 13 A, 13 \text {, and } 14 \text {. }\end{array}$ \\
\hline $\begin{array}{l}\text { Roundtail } \\
\text { chub }\end{array}$ & Gila robusta & Candidate & $\begin{array}{l}\text { The roundtail chub does not occur on any of the lease } \\
\text { tracts; however, it could inhabit the Dolores River, which } \\
\text { flows through lease tracts } 13 \mathrm{~A}, 13 \text {, and } 14 \text {. }\end{array}$ \\
\hline
\end{tabular}

Diagnostic projectile points include large-stemmed and indented base, lanceolate, and large side- and corner-notched varieties. Other artifacts commonly found on Archaic sites are one-hand manos and slab metates. Radiocarbon data suggest three periods of this tradition: Early Archaic (5550 to 3550 B.C.), Middle Archaic (3500 to 2050 B.C.), and Late Archaic (2050 B.C. to A.D. 450) (Chandler et al. 1990).

The Archaic tradition was succeeded by the Formative stage (A.D. 1 to 1300), which is marked by the introduction of horticulture, the construction of more advanced dwellings, and the fabrication of ceramics. Two contemporaneous cultures are associated with the Formative stage in western Colorado-the Fremont in the northwest and the Anasazi in the southwest. However, little evidence exists that west-central Colorado was dominated by either culture; rather, the area may have been occupied by both cultures and by an indigenous people who adopted cultural elements from both the Fremont and Anasazi but 
whose hunting and gathering lifestyle remained more like that of their Archaic predecessors (Chandler et al. 1990).

By the late 13th century, Numic people inhabited western Colorado. Possibly the ancestors of the Utes, these people were primarily hunters and gatherers. With the introduction of the horse in the mid-17th century, the Utes' lifestyle became increasingly dependent upon raiding and upon hunting bison on the plains. Ute occupation is evidenced by extensive toolproduction areas, hunting camps, and processing areas. Specifically associated with the Ute occupation of west-central Colorado are Uncompahgre Brownware ceramics, desert sidenotched and Cottonwood triangular projectile points, and wickiups (brush shelters) (Chandler et al. 1990).

With the removal of the Utes to reservations in the 1880 s, west-central Colorado was opened to Euro-American settlement. Mining, ranching, agriculture, oil and gas development, and recreation and tourism have formed the economic base of the area for more than a century. Of interest to the present study is that, as early as the 1880 s, settlers were drawn to the area, particularly to the Paradox and Gypsum Valleys, by the presence of uranium (from which radium was derived for medical purposes). The towns of Bedrock, Nucla, and Naturita owe their prosperity primarily to the construction of uranium processing plants.

An overall archaeological site density of 17 sites per square mile is reported in BLM's San Juan/San Miguel Resource Management Plan and Environmental Impact Statement (BLM 1984). However, site density in the BLM planning area varies greatly; an inventory of Mockingbird Mesa (south of the Slick Rock lease tracts) yielded more than 100 sites per square mile, the majority of which have been recommended for inclusion in the National Register of Historic Places. The Disappointment and Paradox Valley areas also are known to have high site densities. On the DOE lease tracts, BLM has estimated an average density of 13 sites per square mile.

Among the sites in the general vicinity of the DOE lease tracts that are considered to represent national cultural resource values are Sand/East Rock Canyons, Mockingbird Mesa, Lowry Ruin, Dominguez-Escalante Ruin, Tabeguache Canyon and Hanging Flume. Collectively these sites contain evidence of Archaic through Historic occupation. Cultural resource inventories conducted for the Naturita and Slick Rock Uranium Mill Tailings Remedial Action project sites also yielded evidence of a variety of cultures and identified historic sites, rock shelters, hearth sites, lithic scatters, and isolated projectile points and tools (Jacobs Engineering Group Inc. 1994a and 1994b).

The Uravan lease tracts are very near or overlap areas of known prehistoric occupation as well as areas of early Euro-American settlement and ranching; the Paradox Valley and Slick Rock lease tracts also are located in areas of demonstrated prehistoric occupation, particularly those tracts proximate to the Dolores River canyon. Because of the high site densities in the areas of the DOE lease tracts, it is likely that cultural resources already have been affected adversely by leaseholders' historical surface-disturbing activities. 
BLM has commenced a historical resources inventory of radioactive-minerals-related mining buildings and features. Because some of these resources may be or may become historically significant and eligible for inclusion in the National Register of Historic Places, their identification and evaluation is essential prior to disturbance or reclamation.

\subsection{Visual Resources}

The area encompassing the lease tracts is described by the BLM as having spectacular scenery; it is characterized by broad to narrow river valleys, steep canyons, mesas, rolling parks, mountains, and ridges (BLM 1984).

In the area of the Uravan lease tracts, State Highway 141 has been designated as the Unaweep Tabeguache Scenic and Historic Byway (Byway). The Byway primarily is located in deep-cut valleys along the Dolores and San Miguel Rivers and is bordered by contrasting red rock formations, which rise sharply upward to ridges 1,000 to 1,500 feet (305 to 460 meters) above the Byway. On top of the ridges are densely vegetated mesas. Valley side-slopes generally are sparsely vegetated with small trees, shrubs, and grasses characteristic of a semiarid ecosystem. The Uravan lease tracts are either immediately adjacent to or within the proximity of the Byway. The Outstanding Scenic Area (OSA) closest to the Uravan lease tracts is the Carpenter Ridge OSA, which is approximately 3 miles (5 kilometers) west of lease tract 19. An OSA is an area containing unique landforms or vegetation that is protected by BLM.

The Paradox Valley lease tracts are located on side slopes and ridges adjacent to the wide valley floor and generally are not readily visible from State Highway 90 , which provides primary access to the area. Access from State Highway 90 to the lease tracts is provided by gravel, seasonal, and four-wheel-drive roads. Primary users of this lease tract area include local hunters, grazing permittees, and four-wheel-drive enthusiasts. These areas typically are not considered visual area destinations, although the visual features have considerable merit. The lease tract 7 open-pit mine is visible from State Highway 90, as are other non-DOE mining activities. The Dolores River OSA is approximately 1 mile (1.6 kilometers) west of lease tract 17.

The Slick Rock lease tracts are traversed by or located adjacent to State Highway 141, near the historic community of Slick Rock. This lease tract area is subject to heavy non-DOE mining activities that are visible from the highway. DOE lease tract activity also is readily visible from the highway. Visible signs of activity primarily consist of roads and mine-rock waste piles that have been naturally revegetated. Throughout the area, desert bighorn sheep may be viewed. The Slick Rock lease tracts are approximately 3 miles (5 kilometers) south of the Dolores River OSA. 


\subsection{Wilderness Areas}

No designated Wilderness Areas are located near the DOE lease tracts. The Dolores River Canyon WSA, which is under consideration for wilderness designation, is located near several of the lease tracts. Lease tracts 18 and 25 are approximately 6 miles (10 kilometers) northeast of this WSA; lease tracts $5,6,7,7 \mathrm{~A}, 8$, and 9 are approximately 1 mile (1.6 kilometers) from the northeastern corner of the WSA and 3 miles ( 5 kilometers) from the southeastern corner of the WSA. Lease tracts 17 and 17A are approximately 1 mile (1.6 kilometers) south of the WSA's southernmost extension.

\subsection{Noise}

Noise levels in and near the historical communities of Uravan and Slick Rock are typical of remote Colorado towns. The primary sources of noise are vehicles and equipment or machinery associated with the agricultural and mining industries. In the more remote areas of the DOE lease tracts, noise is created by vehicles used by lessees, recreationists, and landowners, but is relatively infrequent. It is estimated that, on average, fewer than five cars per day use unimproved roads in the lease tract areas. The most frequent traffic noise would be expected to occur during hunting season.

\subsection{Wild and Scenic Rivers}

No sections of the San Miguel River in the area of the Uravan lease tracts are known to be designated or proposed as Wild and Scenic. The Dolores River also has not been designated as Wild or Scenic; however, studies currently are being conducted to determine if sections of the Dolores River near the Slick Rock lease tracts should be proposed for Wild and Scenic status (Jacobs Engineering Group Inc. 1994b).

\subsection{Floodplains and Wetlands}

Portions of Slick Rock lease tracts 13, 13A, and 14 are located within the 100-year floodplain of the Dolores River. Although vegetation surveys have not been conducted, the floodplain contains wetland-type vegetation (e.g., willow, Fremont's cottonwood, reed canarygrass, forestiera, and sedges). Historically, preoperational and operational activities have not occurred on the Dolores River floodplain. River floodplains are not associated with the Uravan or Paradox Valley lease tracts.

Vegetation characteristic of wetland ecosystems appears on lease tracts 7,9 , and 14 . The potential wetland areas on lease tracts 7 and 9 are formed by mine dewatering operations (mine water is pumped to containment ponds); the potential wetland areas on lease tract 14 are formed by storm-water accumulation in small, shallow surface mines. The total area encompassed by these potential wetland areas ranges from 2 to 10 acres ( 1 to 4 hectares). 


\subsection{Human Health}

The mine sites on each of the lease tracts currently are considered inactive; however, both radiological and nonradiological physical hazards that could pose a threat to human health exist on the lease tracts.

\subsubsection{Radiological Hazards}

Long-term exposure to ionizing radiation has been shown to cause a statistical increase in the occurrence of cancer in humans (International Commission on Radiation Protection 1990). Mine sites on the DOE lease tracts comprise rocks and soils that contain naturally occurring radioactive material (NORM); the majority of NORM is derived from the uranium-238 and uranium-235 decay chains. One of the products in these decay chains is radium-226, which is the principal radionuclide of concern for characterizing the redistribution of radioactivity in the environment.

Background levels of radium-226 are normally present in soil in trace concentrations of about 1 picocurie per gram ( $\mathrm{pCi} / \mathrm{g}$ ); however, background concentrations within ore-bearing formations may be as high as hundreds of thousands of picocuries per gram. Background concentrations of radium-226 in mine-rock waste piles average $23.7 \mathrm{pCi} / \mathrm{g}$ (EPA 1991). The primary radioactive sources on the DOE lease tracts are mine-rock waste piles, mine portals, ore-bearing outcrops (Salt Wash Member of the Morrison Formation), and airborne particulates derived from these sources. In underground mines, the primary radium-226 source is the ore-bearing Salt Wash Member.

The amount of radiation that is received by mine workers and members of the public is directly related to the amount of time they spend on or near the radioactive sources and to the level of radioactivity inherent to the sources. At the present time, mine workers typically visit the lease tracts for approximately 3 hours each month of the year, or for a total of 36 hours per year. Because most of the lease tracts are readily accessible by public roads and are not secured by fences or locked gates, members of the public may spend more or less time on the lease tracts than the mine worker. Although members of the public are not permitted to permanently or temporarily reside on the lease tracts, some visitors may camp for 1 or more days. Other activities that bring public visitors to the lease tracts include hunting, hiking, and mountain biking. In general, a public visitor would not spend more than 2 weeks ( 336 hours) per year on the lease tracts.

An individual may be exposed to radiation on the lease tracts through three primary pathways: (1) external exposure to gamma radiation, (2) inhalation and ingestion of resuspended radioactive particulates, and (3) inhalation of radon and radon daughter products. These exposure pathways are analyzed to determine health effects on mine workers and members of the public. Presently, the leaseholders ensure that worker and public exposures do not exceed MSHA, NRC, and EPA regulations (see discussion in Section 3.2 for exposure thresholds). 
To assess exposures to members of the public, DOE evaluated a scenario in which an individual camps on a mine-rock waste pile for 24 hours a day over a 14-day period. This time period was used at the suggestion of EPA (Lammering 1994). Lease tract 13 was selected for assessment because it is the most accessible to the public and because of its close proximity to State Highway 141 and the historical community of Slick Rock. Additionally, this area is popular with visitors for viewing desert bighorn sheep and for rafting the Dolores River. The exposure value resulting from this scenario on lease tract 13 is considered representative of the amount of radiation an individual could be exposed to at any other lease tract because of the physical similarities of all the mine sites and mine-rock waste piles.

The TEDE resulting from exposure was estimated with RESRAD software (Argonne National Laboratory 1993), which is a software package that performs random dose calculations using pathway analysis. The calculated TEDE was $79 \mathrm{mrem} / \mathrm{yr}$; this value does not exceed the NRC standard of $100 \mathrm{mrem} / \mathrm{yr}$. The average value of 0.04 percent $\mathrm{U}_{3} \mathrm{O}_{8}$, derived from historic data collected on lease tract 13, was used in the random dose calculations. Several assumptions also were used in these calculations: natural uranium was assumed to be 99.28 percent uranium-238; the concentration of uranium-235 was assumed to be 5 percent of the uranium-238 concentration (by activity); and uranium-235 and uranium-238 were assumed to be in equilibrium with their decay products. The exposure pathways analyzed included external exposure to gamma radiation, inhalation of contaminated dust and radon (and radon decay products), and ingestion of contaminated soil. The most significant exposure pathway was external exposure from gamma radiation emitted from the mine-rock waste pile, which caused 90 percent of the TEDE.

\subsubsection{Nonradiological Hazards}

Nonradiological hazards at the lease tracts that could pose a threat to human health include unprotected mine openings such as adits, shafts, or inclines/declines. Currently, the lease tracts posing the greatest risk to members of the public from the presence of physical hazards are lease tracts 5, 6, 7, 9, 21, and 22A in the Paradox Valley area; lease tracts 11, 13, 13A, 14, and 15 in the Slick Rock area; and lease tracts 18, 19, and 25 in the Uravan area. 


\subsection{Environmental Impacts}

The environmental impacts associated with the Proposed Action, No Action, and ULMP Termination Alternatives are discussed in this chapter. Impact descriptions under the Proposed Action Alternative have been made on the assumption that mining activities would continue at a level similar to that of historical activities. The types of activities (preoperational, operational, and postoperational) that would occur on the 22 lease tracts are described in Section 3.2 of this EA. New surface disturbances associated with lease tract activities are expected to affect an estimated 250 acres (101 hectares) of previously undisturbed land during the next 10 years. Impact descriptions under the No Action and ULMP Termination Alternatives have been made on the assumption that activities are performed as described in Sections 3.3 and 3.4 of this EA. Table 4 summarizes the impacts that would occur to environmental resources under each alternative.

\subsection{Socioeconomics}

\subsubsection{Proposed Action Alternative}

Under the Proposed Action Alternative, the leaseholders would conduct preoperational, operational, and postoperational activities at a level similar to that which was conducted historically. If the market were to allow a resumption of uranium and vanadium production, the local economies of communities in Montrose, San Miguel, Fremont, and San Juan Counties would be beneficially affected by an increase in the number of jobs (up to an additional 250 for a total of 300 ) and by increases in local wages and secondary wages. The increase in jobs could increase housing construction in the smaller communities near the lease tracts and in Canon City and Blanding near the processing mills.

\subsubsection{No Action and ULMP Termination Alternatives}

Under the No Action and ULMP Termination Alternatives, approximately 50 short-term jobs would be created for conducting reclamation activities. Reclamation activities would most likely be completed within 1 to 2 years; all short-term and existing long-term jobs would then be terminated. The loss of up to 50 short-term and 50 existing long-term jobs would have minimal adverse impacts on the overall economies of the four counties.

\subsection{Transportation}

\subsubsection{Proposed Action Alternative}

Under the Proposed Action Alternative, an average of 30 trucks (or truck-and-pup combinations) per day would transport uranium and vanadium ores to the processing mill 
Table 4. Summary of Environmental Impacts

\begin{tabular}{|c|c|c|c|}
\hline & Proposed Action & No Action & ULMP Termination \\
\hline Socioeconomics & $\begin{array}{l}\text { Up to } 250 \text { additional jobs } \\
\text { would be created; local } \\
\text { wages and secondary wages } \\
\text { would increase. }\end{array}$ & $\begin{array}{l}\text { Up to } 50 \text { short-term jobs would } \\
\text { be created. After } 1-2 \text { years, } \\
\text { these jobs plus the } 50 \text { pre- } \\
\text { existing jobs would be } \\
\text { terminated. }\end{array}$ & $\begin{array}{l}\text { Up to } 50 \text { short-term jobs } \\
\text { would be created. After } 1-2 \\
\text { years, these jobs plus the } 50 \\
\text { pre-existing jobs would be } \\
\text { terminated. }\end{array}$ \\
\hline Transportation & $\begin{array}{l}\text { Approximately } 0.12 \text { fatalities } \\
\text { and } 7.4 \text { injuries per year } \\
\text { would occur as a result of ore } \\
\text { transportation. Radiation } \\
\text { exposures to truck drivers } \\
\text { and members of the public } \\
\text { would be negligible. }\end{array}$ & $\begin{array}{l}\text { Approximately } 0.02 \text { fatalities } \\
\text { and } 1.3 \text { injuries would occur } \\
\text { from transporting currently } \\
\text { stockpiled ore to the processing } \\
\text { mills. Radiation exposures to } \\
\text { truck drivers and members of } \\
\text { the public would be negligible. }\end{array}$ & $\begin{array}{l}\text { Approximately } 0.02 \text { fatalities } \\
\text { and } 1.3 \text { injuries would occur } \\
\text { from transporting currently } \\
\text { stockpiled ore to the } \\
\text { processing mills. Radiation } \\
\text { exposures to truck drivers and } \\
\text { members of the public would } \\
\text { be negligible. }\end{array}$ \\
\hline Mining & $\begin{array}{l}\text { Uranium and vanadium ores } \\
\text { would be immediately } \\
\text { available to DOE; new } \\
\text { reserves might be discovered. }\end{array}$ & $\begin{array}{l}\text { Uranium and vanadium ores } \\
\text { would not be immediately } \\
\text { available to DOE; ores would be } \\
\text { available over the long term. }\end{array}$ & $\begin{array}{l}\text { Uranium and vanadium ores } \\
\text { would not be available } \\
\text { immediately or over the long } \\
\text { term to DOE. }\end{array}$ \\
\hline Recreation & $\begin{array}{l}\text { Increases in noise, dust, and } \\
\text { human activity could detract } \\
\text { recreationists, especially near } \\
\text { the Dolores River Canyon } \\
\text { SRMA. }\end{array}$ & $\begin{array}{l}\text { Recreation activities could } \\
\text { increase in lease tract area as a } \\
\text { result of decreases in noise, } \\
\text { dust, and human activity. }\end{array}$ & $\begin{array}{l}\text { Recreation activities could } \\
\text { increase in lease tract area as } \\
\text { a result of decreases in noise, } \\
\text { dust, and human activity. }\end{array}$ \\
\hline $\begin{array}{l}\text { Timber } \\
\text { Harvesting }\end{array}$ & $\begin{array}{l}\text { Small number of piñon pine } \\
\text { and juniper trees would be } \\
\text { removed. }\end{array}$ & $\begin{array}{l}\text { No impacts to timber resources } \\
\text { would occur. }\end{array}$ & $\begin{array}{l}\text { No impacts to timber resources } \\
\text { would occur. }\end{array}$ \\
\hline $\begin{array}{l}\text { Agriculture and } \\
\text { Grazing }\end{array}$ & $\begin{array}{l}\text { Five to } 8 \text { AUMs would be lost } \\
\text { from surface-disturbing } \\
\text { activities. }\end{array}$ & $\begin{array}{l}\text { Five to } 9 \text { AUMs would be } \\
\text { gained from reclamation of } \\
\text { existing disturbed land. }\end{array}$ & $\begin{array}{l}\text { Five to } 9 \text { AUMs would be } \\
\text { gained from reclamation of } \\
\text { existing disturbed land. }\end{array}$ \\
\hline Air Quality & $\begin{array}{l}\text { Local fugitive dust would } \\
\text { increase slightly; regional air } \\
\text { quality would not be affected. }\end{array}$ & $\begin{array}{l}\text { Local air quality would improve } \\
\text { slightly from reduction of } \\
\text { fugitive dust; regional air } \\
\text { quality would not be affected. }\end{array}$ & $\begin{array}{l}\text { Local air quality would improve } \\
\text { slightly from reduction of } \\
\text { fugitive dust; regional air } \\
\text { quality would not be affected. }\end{array}$ \\
\hline Groundwater & $\begin{array}{l}\text { Groundwater quality is not } \\
\text { expected to be affected by } \\
\text { surface or underground } \\
\text { mining operations. }\end{array}$ & $\begin{array}{l}\text { Groundwater quality is not } \\
\text { expected to be affected by } \\
\text { postoperational activities. }\end{array}$ & $\begin{array}{l}\text { Groundwater quality is not } \\
\text { expected to be affected by } \\
\text { postoperational activities. }\end{array}$ \\
\hline Surface Water & $\begin{array}{l}\text { Surface-water quality is not } \\
\text { expected to be affected by } \\
\text { surface or underground } \\
\text { mining operations. }\end{array}$ & $\begin{array}{l}\text { Dewatering ponds receiving } \\
\text { groundwater discharge could } \\
\text { be eliminated. }\end{array}$ & $\begin{array}{l}\text { Dewatering ponds receiving } \\
\text { groundwater discharge could } \\
\text { be eliminated. }\end{array}$ \\
\hline Solls & $\begin{array}{l}\text { An estimated } 250 \text { acres of } \\
\text { soil would be disturbed; } \\
\text { erosion potential could } \\
\text { increase. }\end{array}$ & $\begin{array}{l}\text { Existing areas of disturbed soils } \\
\text { would be reclaimed; erosion } \\
\text { potential could decrease. }\end{array}$ & $\begin{array}{l}\text { Existing areas of disturbed } \\
\text { soils would be reclaimed; } \\
\text { erosion potential could } \\
\text { decrease. }\end{array}$ \\
\hline Vegetation & $\begin{array}{l}\text { Existing native plant } \\
\text { communities and cryptobiotic } \\
\text { soil crusts would be disturbed } \\
\text { or destroyed on an estimated } \\
250 \text { acres. }\end{array}$ & $\begin{array}{l}\text { Plant cover on existing } \\
\text { disturbed areas would increase; } \\
\text { wetland-type vegetation might } \\
\text { be altered or destroyed on } \\
\text { lease tracts } 7,9 \text {, and } 14 .\end{array}$ & $\begin{array}{l}\text { Plant cover on existing } \\
\text { disturbed areas would } \\
\text { increase; wetland-type } \\
\text { vegetation might be altered or } \\
\text { destroyed on lease tracts } 7,9 \text {, } \\
\text { and } 14 \text {. }\end{array}$ \\
\hline
\end{tabular}


Table 4 (continued). Summary of Environmental Impacts

\begin{tabular}{|c|c|c|c|}
\hline & Proposed Action & No Action & ULMP Termination \\
\hline Wildlife & $\begin{array}{l}\text { Some small animals would } \\
\text { be displaced by mining } \\
\text { operations; mortality of } \\
\text { small animals would increase } \\
\text { slightly. }\end{array}$ & $\begin{array}{l}\text { Small animals would increase on } \\
\text { lease tracts; an unknown } \\
\text { number of bats could be } \\
\text { permanently displaced from } \\
\text { closing mine openings. }\end{array}$ & $\begin{array}{l}\text { Small animals would increase } \\
\text { on lease tracts; an unknown } \\
\text { number of bats could be } \\
\text { permanently displaced from } \\
\text { closing mine openings. }\end{array}$ \\
\hline $\begin{array}{l}\text { Cultural/ } \\
\text { Historical } \\
\text { Resources }\end{array}$ & $\begin{array}{l}\text { Cultural/historical resources } \\
\text { are not expected to be } \\
\text { disturbed. }\end{array}$ & $\begin{array}{l}\text { Cultural/historical resources are } \\
\text { not expected to be disturbed. }\end{array}$ & $\begin{array}{l}\text { Cultural/historical resources } \\
\text { are not expected to be } \\
\text { disturbed. }\end{array}$ \\
\hline Visual Resources & $\begin{array}{l}\text { Visible dust and surface } \\
\text { disturbance would increase. }\end{array}$ & $\begin{array}{l}\text { Visible dust and surface } \\
\text { disturbance would decrease. }\end{array}$ & $\begin{array}{l}\text { Visible dust and surface } \\
\text { disturbance would decrease. }\end{array}$ \\
\hline Wilderness Areas & $\begin{array}{l}\text { The Dolores River Canyon } \\
\text { WSA is not expected to be } \\
\text { affected. }\end{array}$ & $\begin{array}{l}\text { The Dolores River Canyon WSA } \\
\text { would not be affected. }\end{array}$ & $\begin{array}{l}\text { The Dolores River Canyon } \\
\text { WSA would not be affected. }\end{array}$ \\
\hline Noise & $\begin{array}{l}\text { Minor to moderate increases } \\
\text { in loca! noise levels would } \\
\text { occur. }\end{array}$ & $\begin{array}{l}\text { Local noise levels would } \\
\text { decrease over the long term. }\end{array}$ & $\begin{array}{l}\text { Local noise levels would } \\
\text { decrease over the long term. }\end{array}$ \\
\hline $\begin{array}{l}\text { Wild and Scenic } \\
\text { Rivers }\end{array}$ & No impacts would occur. & No impacts would occur. & No impacts would occur. \\
\hline $\begin{array}{l}\text { Floodplains and } \\
\text { Wetlands }\end{array}$ & $\begin{array}{l}\text { Floodplain and wetland areas } \\
\text { are not expected to be } \\
\text { affected. }\end{array}$ & $\begin{array}{l}\text { Wetland determinations would } \\
\text { be made for existing ponds } \\
\text { before they are reclaimed. }\end{array}$ & $\begin{array}{l}\text { Wetland determinations would } \\
\text { be made for existing ponds } \\
\text { before they are reclaimed. }\end{array}$ \\
\hline Human Health & $\begin{array}{l}\text { Radiation exposures to } \\
\text { workers would not exceed } \\
\text { MSHA values; the maximum } \\
\text { radiation exposure to } \\
\text { members of the public } \\
\text { would be } 79 \mathrm{mrem} / \mathrm{yr} \text {; } \\
\text { workers or the public could } \\
\text { be injured as a result of on- } \\
\text { site physical hazards. }\end{array}$ & $\begin{array}{l}\text { The potential for human } \\
\text { exposure to radiation would be } \\
\text { reduced or eliminated. }\end{array}$ & $\begin{array}{l}\text { The potential for human } \\
\text { exposure to radiation would } \\
\text { be reduced or eliminated. }\end{array}$ \\
\hline $\begin{array}{l}\text { Environmental } \\
\text { Justice }\end{array}$ & $\begin{array}{l}\text { Disproportionate impacts } \\
\text { would not occur to minority } \\
\text { or low-income populations. }\end{array}$ & $\begin{array}{l}\text { Disproportionate impacts would } \\
\text { not occur to minority or low- } \\
\text { income populations. }\end{array}$ & $\begin{array}{l}\text { Disproportionate impacts } \\
\text { would not occur to minority or } \\
\text { low-income populations. }\end{array}$ \\
\hline
\end{tabular}

near Canon City, Colorado, or to the mill near Blanding, Utah. An increase of 30 trucks per day along the Canon City Mill Route or along the North and South Routes to the White Mesa Mill is not expected to substantially increase the number of accidents that occur along the routes, increase radiation exposure to humans, or affect the environment.

Under an average-case scenario, 30 trucks per day travelling to Canon City (the longest of the three routes, encompassing 400 miles each way) 6 days a week, would travel a maximum of 7.5 million miles in 1 year. Given the rate of 0.016 fatalities per million vehicle miles (DOT Federal Highway Administration 1994), approximately 0.12 deaths per year could be expected to occur from ore-truck accidents; given the rate of 0.98 injuries per million 
vehicle miles, approximately 7.4 injuries per year could be expected to occur from ore-truck accidents.

Radiation exposure would be a minor hazard associated with transporting ore. If an accident involving a spill were to occur, the truck driver and members of the public at the accident site would be exposed to radiation (from external gamma radiation, inhalation and ingestion of airborne radioparticulates, and inhalation of radon gas) for a short time period until the ore was removed. The driver would be required to follow emergency spill-notification and cleanup procedures. Radiation exposures received during the short time period are expected to be negligible and well below MSHA, DOT, NRC, and EPA standards (see Section 3.2 for a discussion of these standards).

Only the truck driver would be exposed to radiation during normal (without incident) transport of ore, and exposure would be limited to external exposure by gamma radiation. Exposure through inhalation and ingestion of airborne radioparticulates would be eliminated by tarping the trucks; exposure through inhalation of radon and radon daughters would be eliminated by natural dispersion. Radiation exposures received by the driver during ore transport are expected to be negligible and well below MSHA or DOT standards.

Impacts to the environment are expected to be minimal from ore-truck traffic. If a spill were to occur on the ground, the ore would be completely removed, loaded onto a truck, and transported to the mill. Except for soil and vegetation disturbance, impacts to natural resources are not expected to occur from a spill or spill cleanup. If the ore were spilled into a shallow surface-water source, it would be removed before water quality could be adversely affected by the radiological component of the ore. Most ore would be in large enough sizes (e.g., cobbles and stones) that it would be recovered easily from the water source. The finer particles would be dispersed by stream flow and would not create a radiological hazard to aquatic life. The primary impact to water quality from a spill would be a short-term increase in turbidity and total suspended solids.

Wildife would continue to be injured or killed along the haul routes through collisions with trucks. Typically, haul-truck drivers would not take evasive action to avoid wildlife because that action could lead to an accident involving a turnover or collision with another vehicle. Wildlife most likely to be affected would include mule deer, elk, porcupines, rabbits, prairie dogs, ground squirrels, golden eagles, and turkey vultures.

\subsubsection{No Action and ULMP Termination Alternatives}

Some ore transportation could be conducted under these two alternatives. The former leaseholders would have rights to the ore that has already been mined and stockpiled on the lease tracts. Currently, approximately 50,000 tons (45,000 metric tons) of low-grade ore is stockpiled on the lease tracts. Using 30 trucks per day, the leaseholders could transport the ore to the processing mills in approximately 54 days. If the truck drivers were to take the longest route to the Canon City Mill (400 miles each way), the trucks would travel a maximum of 1.3 million miles. Given the 1993 fatality and injury rates (DOT Federal 
Highway Administration 1994), approximately 0.02 fatalities and 1.3 injuries per year could be expected to occur during transport of the ore.

The potential for impacts to humans from radiation exposure and impacts to the environment would be the same as under the Proposed Action Alternative.

\subsection{Land Use}

\subsubsection{Mining}

\subsubsection{Proposed Action Alternative}

Under the Proposed Action Alternative, uranium and vanadium resources would be readily available for mining, milling, and commercial use. Removal of the ore would deplete domestic reserves of vanadium and uranium; however, continued exploration activities could result in the discovery of previously unidentified ore reserves.

\subsubsection{No Action and ULMP Termination Alternatives}

Under the No Action and ULMP Termination Alternatives, uranium and vanadium resources on the DOE lease tracts would not be immediately available for domestic needs. Reserves present on the lease tracts would remain in place for future use under the No Action Alternative but not under the ULMP Termination Alternative. If DOE were to decide to lease the withdrawn lands in the future under the No Action Alternative, much of the mining infrastructure (e.g., access roads, mine sites, portals, buildings) would have to be reconstructed. Acquisition of ores under this alternative would take considerably longer than under the Proposed Action Alternative. Under the ULMP Termination Alternative, future leasing of the withdrawn lands by DOE would not be an option. The lands would be subject to claim location and mineral development and extraction by private entities.

\subsubsection{Recreation}

\subsubsection{Proposed Action Alternative}

Resuming preoperational, operational, and postoperational activities under the Proposed Action Alternative would have minimal effects on recreation in the lease tract areas. Potential increases in noise, dust, and human activity might deter recreationists from using public lands adjacent to the lease tracts; however, the numerous unimproved roads in the vicinity of the lease tracts would allow easy access to other areas. Activities on lease tracts 13,13A, and 14 within the Dolores River Canyon SRMA could potentially detract from the recreational experience of individuals using the Dolores River as a result of increased levels of noise, dust, and human activity. The extent of the detraction would depend on the type and number of operations occurring on the lease tracts. Because most 
activities occurring on the lease tracts would be associated with exploration and underground mining, the potential detractions are expected to be minimal.

\subsubsection{No Action and ULMP Termination Alternatives}

Under the No Action and ULMP Termination Alternatives, cessation of mining operations and reclamation of disturbed areas would beneficially affect recreation in areas of the lease tracts. Recreationists would not be deterred by noise, dust, and human activity on the lease tracts. The reclamation of some existing roads might block access to areas formerly open to the public; however, numerous alternative routes would exist in most lease tract areas.

\subsubsection{Timber Harvesting}

\subsubsection{Proposed Action Alternative}

Under the Proposed Action Alternative, a small number of piñon pine and juniper trees could be removed as a result of access road and drill pad construction or mine site expansion. Because of the abundance of piñon pine and juniper in the lease tract areas, however, impacts to these species would be negligible.

\subsubsection{No Action and ULMP Termination Alternatives}

No impacts to piñon pine and juniper resources would occur under the No Action and ULMP Termination Alternatives.

\subsubsection{Agriculture and Grazing}

\subsubsection{Proposed Action Alternative}

Under the Proposed Action Alternative, a maximum of 5 to 8 AUMs could be lost over a period of 10 years from the additional surface disturbance of 250 acres (101 hectares). This small loss in acreage would not adversely affect the volume of grazing forage in local grazing allotments.

\subsubsection{No Action and ULMP Termination Alternatives}

Under the No Action and ULMP Termination Alternatives, grazing allotments, where present, would be beneficially affected by the reclamation of existing disturbed lands. Assuming all disturbed lands (258 acres or 104 hectares) were reclaimed and suitable for grazing, a net increase of 5 to 9 AUMs would occur. 


\subsection{Air Quality}

\subsubsection{Proposed Action Alternative}

Resumption of lease activities under the Proposed Action Alternative would result in local increases in fugitive dust. Regional air quality is not expected to be affected by these local increases. The leaseholder would be responsible for obtaining an air emission permit from the State of Colorado if lease operations could result in the exceeding of the State opacity limit of 20 percent. It is unlikely that lease tract operations would require air emission permits.

\subsubsection{No Action and ULMP Termination Alternatives}

Short-term increases in fugitive dust would occur under the No Action and ULMP Termination Alternatives during reclamation of the lease tracts; however, regional air quality would not be affected. Over the long term, local air quality would be slightly improved from the reclamation of barren ground.

\subsection{Groundwater}

\subsubsection{Proposed Action Alternative}

Operational, preoperational, and postoperational activities under the Proposed Action Alternative are not expected to adversely affect groundwater resources on any of the lease tracts. The shallowest, significant groundwater is in the Entrada Sandstone. Because this aquifer is generally several hundred feet below the surface at all lease tracts, surfacedisturbing activities would have no effect on the aquifer. Downward percolation of recharge water, which could infiltrate at the surface, would be slowed considerably by the presence of the thick (several hundred feet), relatively impermeable Brushy Basin Member of the Morrison Formation. The Entrada aquifer is hydrologically separated from the surface by the Brushy Basin and Salt Wash Members of the Morrison Formation and by the Summerville Formation.

With the exception of mines on lease tracts 7,9 , and 18, groundwater would not be present in notable amounts within the subsurface areas encountered during mining. In some cases, water would be brought into underground mines during drilling to prevent dust from becoming airborne and to remove cuttings from drill bits. This water would not be present in large enough quantities to transport mineral contaminants from the ore-bearing layer to underlying layers. The Entrada aquifer would not be affected because it is hydrologically separated from the ore-bearing layer by the low-permeability Summerville Formation.

In the three mines where water is present within the ore-bearing layer, groundwater would be pumped into surface treatment ponds. Therefore, it generally would not be available for seepage into underlying layers. Even if groundwater were not pumped and removed, the 
underlying low-permeability layers would retard seepage of the groundwater into the Entrada aquifer. If seepage into the Entrada aquifer were to occur over time, the small amount of groundwater emanating from the ore-bearing layer would not affect groundwater quality within the aquifer.

\subsubsection{No Action and ULMP Termination Alternatives}

Under the No Action and ULMP Termination Alternatives, reclamation activities, including the removal of surface contaminants, would not affect the quantity or quality of groundwater within any aquifer. The cessation of pumping at mines on lease tracts 7, 9, and 18 would not adversely affect water quality in the underlying Entrada aquifer. The low-permeability Summerville Formation would retard seepage of water into the Entrada aquifer. If seepage into the Entrada aquifer were to occur over time, the small amount of water emanating from the ore-bearing layer would not affect groundwater quality within the aquifer.

\subsection{Surface Water}

\subsubsection{Proposed Action Alternative}

On disturbed areas of the lease tracts, the potential for erosion and transportation of contaminant-laden sediments would be minimized by the implementation of storm-water management controls that would be required by the lease agreements and the Colorado Mine Land Reclamation Board. These storm-water management controls would be designed to reduce runoff from lease tract operational features, thus minimizing the amount of runoff reaching a perennial stream or river. Therefore, potential impacts to surface-water sources from storm-water runoff would be negligible.

\subsubsection{No Action and ULMP Termination Alternatives}

Under the No Action and ULMP Termination Alternatives, storm-water management controls implemented by the leaseholder would prevent runoff from affecting nearby surface-water sources. Over the long term, removal or reclamation of lease tract features associated with past mining activities would eliminate potential water-contaminant sources.

Termination of dewatering activities under both of these alternatives would eliminate the conveyance of water to dewatering ponds, thus eliminating point discharges to the environment associated with these ponds. 


\subsection{Soils}

\subsubsection{Proposed Action Alternative}

Under the Proposed Action Alternative, an estimated 250 acres (101 hectares) of soil could be disturbed during preoperational and operational activities. Disturbance of the soil surface and removal of vegetation would increase the soil erosion potential. Adverse impacts would be minimized by incorporating erosion-control techniques (e.g., use of water bars, vegetation, erosion-control fabric, and land contours) in the construction design.

\subsubsection{No Action and ULMP Termination Alternatives}

Under the No Action and ULMP Termination Alternatives, soils would be beneficially affected over the long term from the reclamation of barren areas. Recontouring and reseeding would reduce the erosion potential of these areas and allow the existing soils to stabilize.

\subsection{Vegetation}

\subsubsection{Proposed Action Alternative}

Preoperational and operational activities under the Proposed Action Alternative could disturb or destroy native plant communities on an estimated 250 acres (101 hectares) of presently undisturbed land. Cryptobiotic soil crusts also would be affected by surface disturbances. These crusts could be destroyed by relatively minor disturbances such as foot traffic. Destruction of cryptobiotic soil crusts would lead to increased erosion, decreased nutrient availability to plants, decreased water-holding capacity of the soil, and reduced seed germination and plant establishment (Belnap 1992).

The boundaries of three lease tracts $(13,13 \mathrm{~A}$, and 14) lie along the Dolores River and have vegetation characteristic of wetland ecosystems. Disturbances in these areas would require consultation with $\mathrm{COE}$ and compliance with DOE environmental review requirements for floodplains and wetlands codified at 10 CFR 1022. Any new surface disturbance would require prior DOE approval.

\subsubsection{No Action and ULMP Termination Alternatives}

Under the No Action and ULMP Termination Alternatives, beneficial impacts would result from the termination of preoperational and operational activities. Loss of habitats, plant communities, and cryptobiotic soil crusts would be minimal under these alternatives as compared to the Proposed Action Alternative. Reclamation activities on the existing 258 acres (104 hectares) of disturbance would increase plant cover. Over the long term, cryptobiotic soil crusts might form in the reclaimed areas, which would increase soil waterholding capacity and plant growth. 
Wetland-type vegetation might be destroyed or altered as a result of mine abandonment and reclamation on lease tracts 7,9 , and 14 . The wetland-type vegetation is associated with dewatering ponds and storm-water accumulation in small, shallow surface mines.

If groundwater were no longer pumped to the dewatering ponds, the ponds would be removed and the area would be reclaimed. The ponds in the small, shallow surface mines could be filled during recontouring operations. The drier soils would probably not support the existing wetland-type vegetation but would suppoirt native or adapted desert species.

\subsection{Wildlife}

\subsubsection{Proposed Action Alternative}

Under the Proposed Action Alternative, wildlife habitat would likely be lost as a result of vegetation removal, surface disturbance, and rock blasting during preoperational and operational activities. For animals that have large home ranges (e.g., deer, birds of prey, coyotes), mine-related habitat loss would have only minimal impacts. For animals that have small home ranges or that have specific habitat requirements (e.g., rodents, rabbits, and bats), displacement and some loss of population would be expected.

Wildlife displacement from increased noise, light, traffic, and other human activities probably would occur to some extent on all of the lease tracts. Large mobile animals would be affected less than small animals that depend exclusively on local habitat. A negligible number of small animals also would be lost as a result of accidental roadkill.

\subsubsection{No Action and ULMP Termination Alternatives}

In general, beneficial impacts to wildlife would occur under the No Action and ULMP Termination Alternatives. Cessation of preoperational and operational activities would reduce or eliminate noise, traffic, and human activity and would allow wildlife, particularly small animals, to return to the lease tracts. Reclamation of disturbed areas also would increase wildlife habitat on the lease tracts.

A small number of southwestern willow flycatchers, other neotropical migratory birds, and waterfowl might be displaced under these alternatives if the dewatering of storm-water accumulation ponds on lease tracts 7,9 , and 14 were reclaimed and the water source eliminated. It is likely that the displaced species would relocate to other riparian areas on or near the lease tracts.

An unknown number of bats might be permanently displaced under these alternatives when mine entrances were closed. Displacement could result in some mortality as bats searched for new roosting sites. The Colorado Division of Wildlife offers guidelines on the use of bat grates (mine closures that allow bats to pass in and out of a mine but prohibit humans from entering mines); however, the agency does not currently require the use of these grates. Unless a $T \& E$ bat species was determined to inhabit lease tract mines, DOE would not be 
obligated to provide habitat unless certain mines were considered critical habitat. DOE might require leaseholders to install bat grates on a case-by-case basis.

\subsection{Cultural/Historical Resources}

\subsubsection{Proposed Action Alternative}

Under the Proposed Action Alternative, an estimated 250 acres (101 hectares) of previously undisturbed land might be disturbed during preoperational and operational activities. Given a site density of 13 sites per square mile, approximately five cultural/historical sites are expected to occur within this acreage. The leaseholder would be required to inventory the areas targeted for disturbance and, if cultural/historical sites were present, to develop a mitigation plan to protect the sites. The State Historic Preservation Officer would approve the mitigation plan before surface disturbance was approved by DOE. With implementation of mitigation measures, adverse impacts to existing cultural/historical resources are expected to be negligible.

\subsubsection{No Action and ULMP Termination Alternatives}

Under the No Action and ULMP Termination Alternatives, no new surface disturbances are expected to occur, and existing disturbances would be reclaimed. Closure of roads on the lease tracts would reduce potential access by vandals to cultural/historical sites.

\subsection{Visual Resources}

\subsubsection{Proposed Action Alternative}

Under the Proposed Action Alternative, the primary impacts to visual resources would be from landscape disturbance associated with preoperational and operational activities; visible dust and barren areas would be the primary impacts. The severity of the visual impacts would be dependent on the location of the disturbance and its visibility from access roads or corridors. Neither the Carpenter Ridge nor the Dolores River OSAs are expected to be affected by lease tract activities because of the natural barriers that occur between the lease tracts and the OSAs. Overall, proposed activities are not expected to adversely affect natural contrasts, colors, or skylines that occur throughout the lease tract areas.

\subsubsection{No Action and ULMP Termination Alternatives}

Because new surface disturbance would not occur under the No Action and ULMP Termination Alternatives, visual resources would not be affected. Over the long term, visual resources would be improved through reclamation of currently disturbed areas. Neither the Carpenter Ridge nor the Dolores River OSAs are expected to be affected by reclamation activities. 


\subsection{Wilderness Areas}

\subsubsection{Proposed Action Alternative}

Under the Proposed Action Alternative, preoperational and operational activities on lease tracts 17 and 17A could adversely affect the Dolores River Canyon WSA. However, the likelihood of this occurring would be remote. Only activities that occurred on the uppermost elevations of the lease tracts would be visible from or within hearing distance of the WSA. The lease tracts are approximately 1 mile (1.6 kilometers) south of the WSA and are geographically separated from the WSA by deep canyons. Exploratory drilling, which has occurred historically, would be the most likely activity to occur on the upper elevations of the lease tracts. Depending upon the wind direction and velocity, a WSA visitor could potentially see dust or hear noise emanating from the lease tracts. Because drilling is typically short term, the impacts, if any, are not anticipated to be long term. If mining were to occur on the lease tracts, operational activities would most likely occur at the lower elevations along the side slopes of Wedding Bell and Radium Mountains. These activities would not be visible from the WSA.

\subsubsection{No Action and ULMP Termination Alternatives}

Impacts to the Dolores River Canyon WSA would not occur under the No Action or ULMP Termination Alternatives because new surface-disturbing activities would not occur.

\subsection{Noise}

\subsubsection{Proposed Action Alternative}

Minor to moderate increases in local noise levels would occur under the Proposed Action Alternative on lease tracts where preoperational and operational activities occurred. Noise associated with preoperational activities such as drilling and access-road construction generally would be short term; noise associated with operational activities probably would be intermittent but long term.

\subsubsection{No Action and ULMP Termination Alternatives}

Under the No Action and ULMP Termination Alternatives, local noise levels would increase over the short term during implementation of reclamation activities. After completion of reclamation, local noise levels would decrease.

\subsection{Wild and Scenic Rivers}

The sections of the Dolores River that are proposed for Wild and Scenic status would not be affected by any of the alternatives. 


\subsection{Floodplains and Wetlands}

\subsubsection{Proposed Action Alternative}

Lease tracts 7,9 , and 14 contain wetland-type vegetation that is supported by mine dewatering activities and storm-water accumulation. If mining activities warranted the dredging or filling of areas containing wetland-type vegetation, compliance with the Clean Water Act could be required, depending on whether the areas were considered "waters of the U.S." under COE regulations (U.S. Army 1987). If mining activities were proposed within a floodplain or wetland area, compliance with DOE's environmental review requirements, codified at 10 CFR 1022, also would be required. Floodplain and wetland areas are not expected to be adversely affected under this alternative.

\subsubsection{No Action and ULMP Termination Alternatives}

The conveyance of mine waters to dewatering ponds on lease tracts 7 and 9 could be terminated under the No Action and ULMP Termination Alternatives, resulting in the destruction of 'wetland-type vegetation. The reclamation of small, shallow surface mines on lease tract 14 would similarly affect wetland-type vegetation. Destruction of the vegetation and pond areas might be in violation of the Clean Water Act, depending on whether the ponds were considered "waters of the U.S." under COE regulations. If reclamation activities were proposed within a floodplain or wetland area, compliance with DOE's environmental review requirements, codified at 10 CFR 1022, would be required.

\subsection{Human Health}

\subsubsection{Proposed Action Alternative}

Under the Proposed Action Alternative, humans could be exposed to radiological and nonradiological hazards on the lease tracts. The level of impact would depend upon the type and level of mine operation. During all phases of mine operation, the leaseholder would be required to ensure protection of workers by providing proper training and protective equipment, as specified by MSHA. The leaseholder also would be responsible for controlling public access to the mine sites during all phases of mine operation.

\subsubsection{Radiological Hazards}

Surface- and underground-mine workers would be exposed to increased levels of radiation through three primary exposure pathways: (1) external exposure to gamma radiation, (2) inhalation and ingestion of resuspended radioactive particulates, and (3) inhalation of radon or radon daughter products. Exposures to resuspended radioactive particulates would be negligible relative to exposures from the other two pathways (EPA 1991). The leaseholder would be required to ensure that exposures to mine workers would not exceed threshold values established by MSHA (see Section 3.2 for discussion of exposure thresholds). 
Radiation exposures to members of the public would be the same as or less than the exposures calculated for current conditions on the lease tracts (see Subsection 4.17.1).

During mine operations, leaseholders would be required to restrict access to the mine sites to adequately ensure public safety. The maximum TEDE from internal and external radiation is expected to be $79 \mathrm{mrem} / \mathrm{yr}$ for a member of the public, which is below the NRC standard of $100 \mathrm{mrem} / \mathrm{yr}$. Ninety percent of this TEDE would be from external exposure to gamma radiation.

\subsubsection{Nonradiological Hazards}

Under the Proposed Action Alternative, the nonradiological hazards that would pose the greatest potential threat to lease tract workers would be those associated with the uranium mining industry in general (e.g., drilling, blasting, ore and waste tramming, tripping, falling, rock falls, cave-ins, and oxygen-deficient atmospheres). Accidents involving these hazards could lead to physical injury or even death. The potential for accidents would be diminished by the leaseholders' strict adherence to industry regulations and proper training of all workers.

For members of the public, the primary nonradiological hazard would stem from unauthorized entry into mine workings. Once entry was gained, the individual(s) would be subject to potential hazards including tripping, falling, rock falls, cave-ins, and oxygendeficient atmospheres. Accidents involving these hazards could lead to physical injury or death. The potential for accidents would be diminished by the leaseholder posting and securing all underground openings.

Another potential nonradiological hazard on the lease tracts would be exposure to toxic elements (e.g., selenium, molybdenum, vanadium, uranium, lead, nickel, and arsenic) that are associated with uranium mining operations. These elements are found mainly within the sediments in mine-rock waste piles and temporary ore stockpiles. The possibility of exposure to these elements would be negligible because an individual would have to ingest or inhale sediments to be affected.

\subsubsection{No Action and ULMP Termination Alternatives}

\subsubsection{Radiological Hazards}

Under the No Action and ULMP Termination Alternatives, the potential for human exposure to radiation would be reduced from that under the Proposed Action Alternative once the mine sites were reclaimed. The degree to which exposures would be reduced would depend on the reclamation method used - some methods would involve removal and burial of radioactive sources, whereas other methods would involve only recontouring and seeding. For both methods, the potential for adverse human-health effects after reclamation are expected to be negligible. 


\subsubsection{Nonradiological Hazards}

Under the No Action and ULMP Termination Alternatives, most of the nonradiological hazards on the lease tracts would be eliminated upon completion of reclamation.

\subsection{Environmental Justice Considerations}

Executive Order 12898, Federal Actions to Address Environmental Justice in Minority Populations and Low-Income Populations, states that Federal programs and actions shall not disproportionately affect minority or low-income populations. None of the alternatives addressed in this EA would adversely affect any particular cultural or socioeconomic group of people more than the population as a whole. The populations of the communities that would most likely be affected by the alternatives are culturally and economically diverse. Likewise, current and potential employees of DOE leaseholders are and would be drawn from a culturally and economically diverse population.

\subsection{Comparison of Alternatives}

Under the Proposed Action Alternative, the intensity of activity and the duration of the program (10 years) would not seriously affect the resources identified in this chapter over the long term. Operations that would occur under the Proposed Action Alternative would result in a negligible increase in overall activity within the lease tract region (Uravan Mineral Belt). The total area of surface disturbance within the 22 lease tracts $(11,536$ acres or 4,670 hectares) is expected to be no more than 508 acres (206 hectares) -258 acres (104 hectares) of existing disturbance and 250 acres (101 hectares) of additional disturbance. As a result of the increased activity, the socioeconomics of nearby communities would be enhanced. The other potential benefit under this alternative would be the preservation of wetland-type vegetation and associated wildlife habitat at lease tracts 7, 9, and 14 .

Under the No Action and ULMP Termination Alternatives, most resources would realize a net positive impact, primarily through reducing access to remote areas of the lease tracts and reclaiming roads that historically have served the lease tracts. Socioeconomics would be adversely impacted over the long term by the elimination of work opportunities associated with exploration and mining activities on the lease tracts. 


\section{Intentionally Blank}




\subsection{List of Persons Consulted}

Myron Brown

Eric Chang

Mack Christensen

Roger Gilpin

Tom Hurshman

Tom Ingersol

Dennis Keller

Dick Langoni

Lynn Lewis

John Milburn
Captain, Colorado State Patrol

Grand Junction, Colorado

Traffic Safety Analyst

Utah Department of Transportation

Salt Lake City, Utah

Traffic Safety Engineer

Utah Department of Transportation

Salt Lake City, Utah

Colorado Department of Transportation

Denver, Colorado

Land Specialist

Montrose District BLM

Montrose, Colorado

Wildlife Biologist

Colorado Division of Wildlife

Denver, Colorado

Colorado Department of Transportation Denver, Colorado

Traffic Engineer

Colorado Department of Transportation

Durango, Colorado

Geologist

Montrose District BLM

Montrose, Colorado

Labor and Employee Specialist

Colorado Job Service Center

Canon City, Colorado 
Jim Nall

Keith Rose

Robert Welch
Traffic Engineer

Colorado Department of Transportation

Durango, Colorado

Assistant Colorado State Field Supervisor

U.S. Fish and Wildlife Service

Grand Junction, Colorado

Biologist

BLM Montrose District

Montrose, Colorado 


\subsection{References}

10 CFR 20, U.S. Nuclear Regulatory Commission, "NRC Standards for Protection Against Radiation," U.S. Code of Federal Regulations.

10 CFR 760, U.S. Department of Energy, "Domestic Uranium Program," U.S. Code of Federal Regulations.

10 CFR 1021, U.S. Department of Energy, "National Environmental Policy Act Implementing Procedures," U.S. Code of Federal Regulations.

10 CFR 1022, U.S. Department of Energy, "Compliance with Floodplain/Wetlands Environmental Review Requirements," U.S. Code of Federal Regulations.

30 CFR 57, Mine Safety and Health Administration, Department of Labor, "Safety and Health Standards-Underground Metal and Nonmetal Mines," U.S. Code of Federal Regulations.

40 CFR 61, U.S. Environmental Protection Agency, "National Emission Standards for Hazardous Air Pollutants," U.S. Code of Federal Regulations.

Argonne National Laboratory, 1993. Manual for Implementing Residual Radioactive Material Guidelines Using RESRAD, Version 5.0, draft, ANL/EAD/LD, Argonne, Dlinois.

Belnap, Jayne, 1992. Potential Role of Cryptobiotic Soil Crusts in Semiarid Rangelands, presented at the Symposium on Ecology, Management, and Restoration of Intermountain Annual Rangelands, Boise, Idaho, May 18-22, 1992.

Chandler, Susan M., Jonathan C. Horn, and Alan D. Reed, 1990. Cultural Resource Overview for the Proposed TransColorado Natural Gas Pipeline, Western Colorado and Northwestern New Mexico, prepared for Woodward-Clyde Consultants, Oakland, California.

Colorado Department of Health, 1986. Classifications and Numeric Standards for Gunnison and Lower Dolores River Basins, Water Quality Control Commission, Denver, Colorado.

Colorado Department of Natural Resources, 1995. Mineral Rules and Regulations of the Colorado Mined Land Reclamation Board, Division of Minerals and Geology, Denver, Colorado.

Cotter Corporation, 1979. Cotter Corporation JD-7 Mine Plan (looseleaf notebook), Denver, Colorado.

Executive Order 12898, Federal Actions to Address Environmental Justice in Minority Populations and Low-Income Populations. 
Ford, Bacon, and Davis, Inc., 1981. Engineering Assessment of Inactive Uranium Mill Tailings, Slick Rock Sites, Slick Rock, Colorado, DOE/UMT-0115, prepared for the U.S. Department of Energy, Salt Lake City, Utah.

Hurshman, Tom, 1994. Personal communication between Tom Hurshman, Land Specialist, Montrose District BLM, Montrose, Colorado, and Robert Bleil, Rust Geotech, Grand Junction, Colorado, October 17, 1994.

Hurshman, Tom, and Lynn Lewis, 1994. Personal communication between Tom Hurshman, Land Specialist, and Lynn Lewis, Montrose District BLM, Montrose, Colorado, and Robert Bleil, Rust Geotech, Grand Junction, Colorado, July 8, 1994.

Ingersol, Tom, 1994. Personal communication between Tom Ingersol, Colorado Division of Wildlife, Denver Colorado, and Alix Craig, Rust Geotech, Grand Junction, Colorado, October 6, 1994.

International Commission on Radiological Protection, 1990. Recommendations of the International Commission on Radiological Protection, ICRP Publication No. 60.

Jacobs Engineering Group Inc., 1994a. Environmental Assessment of Remedial Action at the Naturita Uranium Processing Site Near Naturita, Colorado, prepared for the U.S.

Department of Energy UMTRA Project Office, Albuquerque, New Mexico.

, 1994b. Environmental Assessment of Remedial Action at the Slick Rock Uranium Mill Tailings Sites, Slick Rock, Colorado, DOE/EA-0339, Rev. 1, prepared for U.S. Department of Energy UMTRA Project Office, Albuquerque, New Mexico.

Lammering, Milton W., Ph.D., 1994. Letter regarding reasonable human exposure scenarios, from Milton Lammering, Chief Radiation and Indoor Air Programs Branch, U.S. Environmental Protection Agency, to DOE-GJPO, February 24, 1994.

Navo, Kirk W. Letter regarding draft EA for the Uranium Lease Management Program from Kirk W. Navo, Bats/Inactive Mines Project Leader, Colorado Division of Wildlife, Monte Vista, Colorado, to Ray Plieness, DOE-GJPO, June 29, 1995.

Rose, Keith, 1993. Letter regarding threatened and endangered species on U.S. Department of Energy uranium lease sites in Mesa, Montrose, and San Miguel Counties, Colorado, from Keith Rose, Assistant Colorado State Field Supervisor, U.S. Fish and Wildlife Service, Grand Junction, Colorado, and Lisa Lesperance, Rust Geotech, Grand Junction, Colorado, September 1, 1993.

U.S. Atomic Energy Commission, 1970. Unit C-SR-13, Georgetown \& Middle Group Area, San Miguel County, Colorado, information packet on file at U.S. Department of Energy Grand Junction Projects Office, Grand Junction, Colorado. 
U.S. Army, 1987. Corps of Engineers Wetlands Delineation Manual, Technical Report Y-87-1, Environmental Laboratory, Waterways Experiment Station, Corps of Engineers, Vicksburg, Michigan.

U.S. Bureau of Reclamation, 1978. Colorado River Basin Salinity Control Project, Paradox Valley Unit, Draft Environmental Statement, Upper Colorado Regional Office, Salt Lake City, Utah.

U.S. Department of Commerce, 1992. 1990 Census of Population and Housing, Summary Social, Economic, and Housing Characteristics-Colorado, Bureau of the Census, 1990 CPH-5-7.

U.S. Department of Energy, 1994a. Letter from R. Eldon Bray, U.S. Department of Energy Grand Junction Projects Office, to former leaseholders requesting information to prepare environmental assessment for the Uranium Lease Program (lease-specific information). August 5, 1994.

, 1994b. Letter from Robert E. Ivey, U.S. Department of Energy Grand Junction Projects Office, to former leaseholders regarding the Uranium Lease Management Program Environmental Assessment Proposed Action, granting of access to property, requesting leaseholders' intent for program participation. September 1, 1994.

U.S. Department of Interior Bureau of Land Management, 1984. San Juan/San Miguel Resource Management Plan and Environmental Impact Statement, Montrose District, Montrose, Colorado.

Environmental Assessment CO-030-U-93-36, Uncompahgre Basin Resource Area, Montrose District, Montrose, Colorado.

U.S. Department of Transportation Federal Highway Administration, 1994. 1993 Highway Statistics, Office of Highway Information Management, Washington, D.C.

U.S. Environmental Protection Agency, 1991. Diffuse NORM: Waste Characterization and Preliminary Risk Assessment, Draft, Office of Radiation Programs, Washington D.C.

U.S. Forest Service, U.S. National Park Service, U.S. Bureau of Land Management, Utah Natural Heritage Program, U.S. Fish and Wildlife Service, Environmental Protection Agency, Navajo Nation, and Skull Valley Goshute Tribe, 1991. Utah Endangered, Threatened and Sensitive Plant Field Guide, Salt Lake City, Utah.

Welch, Robert 1994. Personal communication between Robert Welch, BLM Montrose District, Montrose, Colorado, and Alix Craig, Rust Geotech, Grand Junction, Colorado, October 6, 1994. 
Intentionally Blank

ULMP EA

Page 72 


\section{Appendix A \\ Plant and Wildlife Species On or Near DOE Lease Tracts}




\section{Intentionally Blank}


Table A-1. Common and Scientific Names of Plants Associated With

DOE Lease Tracts

\begin{tabular}{|c|c|}
\hline Scientific Name & Common Name \\
\hline $\begin{array}{l}\text { Sporobolus airoides (Torr.) Torr } \\
\text { Purshia tridentata (Pursh) DC. } \\
\text { Balsamorhiza sagittata (Pursh) Nutt. } \\
\text { Yucca baccata Torr. } \\
\text { Artemisia tridentata Nutt. } \\
\text { Bouteloua gracilis (Willd. ex Kunth) Lag. ex Griffiths } \\
\text { Lactuca tatarica var. pulchella (Pursh) Breitung } \\
\text { Eriogonum sp. } \\
\text { Artemisia spinescens D.C. Eat. } \\
\text { Poa bulbosa L. } \\
\text { Typha latifolia L. } \\
\text { Bromus tectorum var tectorum L. } \\
\text { Prunus virginiana var. melanocarpa (A. Nels) Sarg. } \\
\text { Xanthium strumarium L. } \\
\text { Sporobolus contractus A.S. Hitchc. } \\
\text { Agropyron cristatum (L.) Gaertn. } \\
\text { Cryptantha sp. } \\
\text { Cercocarpus ledifolius Nutt. } \\
\text { Rumex crispus L. } \\
\text { Lygodesmia doloresensis S. Tomb. } \\
\text { Sphaeralcea coccinea ssp. coccinea (Nutt.) Rydb. } \\
\text { Convolvulus arvensis L. } \\
\text { Thlaspi arvense L. } \\
\text { Erodium cicutarium (L.) L'Her. ex Ait. } \\
\text { Descurainia sophia (L.) Webb ex Prantl } \\
\text { Forestiera neomexicana Gray } \\
\text { Mirabilis multiflora (Torr.) Gray } \\
\text { Atriplex canescens (Pursh) Nutt. } \\
\text { Populus fremontii S. Wats } \\
\text { Hordeum jubatum ssp. jubatum L. } \\
\text { Artemisia frigida Willd } \\
\text { Hilaria jamesii (Torr.) Benth } \\
\text { Quercus gambelii Nutt. } \\
\text { Heterotheca villosa ssp. villosa (Pursh) Shinners } \\
\text { Tetradymia canescens DC. } \\
\text { Sarcobatus vermiculatus (Hook.) Torr. } \\
\text { Nassella viridula (Trin.) Barkworth } \\
\text { Chrysothamnus viscidiflorus ssp. viscidiflorus (Hook.) Nutt. } \\
\text { Grindelia squarrosa (Pursh) Dunal } \\
\text { Halogeton glomeratus (Bieb.) C.A. Mey } \\
\text { Yucca harrimaniae Trel. } \\
\text { Castilleja sp. } \\
\text { Oryzopsis hymenoides (Roemer \& J.A. Schultes) Ricker ex Piper } \\
\text { Koelaria macrantha (Ledeb.) J.A. Schultes } \\
\text { Erigeron kachinensis Welsh \& Moore } \\
\text { Kochia scoparia (L.) Schrad. } \\
\text { Ephedra viridis var. varidis Coville } \\
\text { Artemisia tridentata ssp. vaseyana (Rydb.) Beetle } \\
\text { Astragalus naturitensis Payson } \\
\text { Lerassus Payson }\end{array}$ & $\begin{array}{l}\text { alkali sacaton } \\
\text { antelope bitterbrush } \\
\text { arrowleaf balsamroot } \\
\text { banana yucca } \\
\text { big sagebrush } \\
\text { blue grama } \\
\text { blue lettuce } \\
\text { buckwheat } \\
\text { bud sagebrush } \\
\text { bulbous bluegrass } \\
\text { broadleaf cattail } \\
\text { cheatgrass } \\
\text { black chokecherry } \\
\text { rough cocklebur } \\
\text { spike dropseed } \\
\text { crested wheatgrass } \\
\text { catseye } \\
\text { curlleaf mountain mahogany } \\
\text { curly dock } \\
\text { Dolores River skeletonplant* } \\
\text { scarlet globemallow } \\
\text { field bindweed } \\
\text { field pennycress } \\
\text { redstem stork's bill } \\
\text { herb sophia } \\
\text { forestiera } \\
\text { Colorado four o'clock } \\
\text { fourwing saltbush } \\
\text { Fremont's cottonwood } \\
\text { bobtail barley } \\
\text { fringed sagewort } \\
\text { galleta grass } \\
\text { Gambel's oak } \\
\text { hairy goldenaster } \\
\text { spineless horsebrush } \\
\text { greasewood } \\
\text { green needlegrass } \\
\text { green rabbitbrush } \\
\text { curlycup gumweed } \\
\text { halogeton } \\
\text { Spanish bayonet } \\
\text { indian paintbrush } \\
\text { Indian ricegrass } \\
\text { prairie Junegrass } \\
\text { kachina fleabane* } \\
\text { common kochia } \\
\text { mormon tea } \\
\text { mountain big sagebrush } \\
\text { Naturita milkvetch } \\
\text { true mountain mahogany } \\
\text { milkvetch } \\
\text { needleandthread } \\
\text { Oregongrape } \\
\text { Paradox lupine* }\end{array}$ \\
\hline
\end{tabular}


Table A-1 (continued). Common and Scientific Names of Plants Associated With DOE Lease Tracts

\begin{tabular}{|c|c|}
\hline Scientific Name & Common Name \\
\hline $\begin{array}{l}\text { Penstemon sp. } \\
\text { Phlox longifolia Nutt. } \\
\text { Amaranthus blitoides S. Wats } \\
\text { Pinus edulis Engelm. } \\
\text { Pinus ponderosa P. \& C. Lawson } \\
\text { Lactuca serriola L. } \\
\text { Opuntia polyacantha var. polyacantha Haw } \\
\text { Oenothera sp. } \\
\text { Elytrigia intermedia (Host) Nevski } \\
\text { Machaeranthera canescens (Pursh) Gray } \\
\text { Polypogon monspeliensis (L.) Desf. } \\
\text { Aristida purpurea var. purpurea Nutt. } \\
\text { Phalaris arundinacea L. } \\
\text { Petradoria pumila (Nutt.) Greene } \\
\text { Juniperus scopulorum Sarg. } \\
\text { Chrysothamnus nauseosus ssp. nauseosus (Pallas ex Pursh) Britt. } \\
\text { Acroptilon repens (L) DC. } \\
\text { Salsola kali L. } \\
\text { Psathyrostachys juncea (Fisch.) Nevski } \\
\text { Leymus salinus ssp. salinus (M.E. Jones) A. Love } \\
\text { Poa secunda J. Presl } \\
\text { Sporobolus cryptandrus (Torr.) Gray } \\
\text { Atriplex confertifolia (Torr. \& Frem.) S. Wats. } \\
\text { Fraxinus anomala Torr. ex S. Wats. } \\
\text { Lygodesmia sp. } \\
\text { Rhus trilobata var. trilobata Nutt. } \\
\text { Elytrigia elongata (Host) Nevski } \\
\text { Bromus inermis ssp. inermis var. inermis Leyss. } \\
\text { Gutierrezia sarothrae (Pursh) Britt. \& Rusby } \\
\text { Symphoricarpos longiflorus Gray } \\
\text { Elymus elymoides (Raf.) Swezey } \\
\text { Peraphyllum ramosissimum Nutt. } \\
\text { Helianthus annus L. } \\
\text { Lepidium latifolium L. } \\
\text { Tamarix ramosissima Ledeb. } \\
\text { Sisymbrium altissimum L. } \\
\text { Juniperus osteosperma (Torr.) Little } \\
\text { Amelanchier utahensis Koehne } \\
\text { Pascopyrum smithii (Rydb.) A. Love } \\
\text { Achillea millefolium L. } \\
\text { Astragalus wetherillii M.E. Jones } \\
\text { Cardaria draba (L.) Desv. } \\
\text { Krascheninnikovia lanata (Pursh) Guldenstaedit } \\
\text { Melilotus officinalis (L.) Lam } \\
\text { Salix spp. } \\
\text { Elaeagnus angustifolia L. }\end{array}$ & $\begin{array}{l}\text { penstemon } \\
\text { longleaf phlox } \\
\text { mat amaranth } \\
\text { twoneedle piñon } \\
\text { ponderosa pine } \\
\text { prickly lettuce } \\
\text { hairspine pricklypear } \\
\text { primrose } \\
\text { pubescent wheatgrass } \\
\text { hoary aster } \\
\text { annual rabbitsfoot grass } \\
\text { purple threeawn } \\
\text { reed canarygrass } \\
\text { grassy rockgoldenrod } \\
\text { Rocky Mountain juniper } \\
\text { rubber rabbitbrush } \\
\text { Russian knapweed } \\
\text { prickly Russian thistle } \\
\text { Russian wildrye } \\
\text { saline wildrye } \\
\text { Sandberg bluegrass } \\
\text { sand dropseed } \\
\text { saltbush } \\
\text { singleleaf ash } \\
\text { skeletonplant } \\
\text { skunkbush sumac } \\
\text { slender wheatgrass } \\
\text { smooth brome } \\
\text { broom snakeweed } \\
\text { desert snowberry } \\
\text { bottlebrush squirreltail } \\
\text { squaw apple } \\
\text { common sunflower } \\
\text { broadleaved pepperweed } \\
\text { saltcedar } \\
\text { tall tumblemustard } \\
\text { Utah juniper } \\
\text { Utah serviceberry } \\
\text { western wheatgrass } \\
\text { common yarrow } \\
\text { Wetherill's milkvetch* } \\
\text { pepperweed whitetop } \\
\text { winterfat } \\
\text { yellow sweetclover } \\
\text { willows } \\
\text { Russian olive }\end{array}$ \\
\hline
\end{tabular}

\footnotetext{
*Sensitive species.
} 
Table A-2. Wildlife Species Expected to Occur

On or Near the DOE Lease Tracts

\begin{tabular}{|c|c|}
\hline Scientific Name & Common Name \\
\hline \multicolumn{2}{|l|}{ Fish } \\
\hline Catostomus discobolus & bluehead sucker \\
\hline Catostomus latipinnis & flannelmouth sucker \\
\hline Lepomis cyanellus & green sunfish \\
\hline Cottus bairdi & mottled sculpin \\
\hline Cyprinus carpio & common carp \\
\hline Gila robusta & roundtail chub \\
\hline Cyprinella lutrensis & red shiner \\
\hline Notropis stramineus & sand shiner \\
\hline Pimephales promelas & fathead minnow \\
\hline Rhinichthys osculus & speckled dace \\
\hline lctalurus punctatus & channel catfish \\
\hline Ameiurus melas & black bullhead \\
\hline Ptychocheilus lucius & Colorado squawfish \\
\hline Xyrauchen texanus & razorback sucker \\
\hline Gila cypha & humpback chub \\
\hline Gila elegans & bonytail chub \\
\hline \multicolumn{2}{|l|}{ Reptiles and Amphibians } \\
\hline Ambystoma tigrinum & tiger salamander \\
\hline Scaphiopus intermontanus & Great Basin spadefoot \\
\hline Bufo punctatus & red-spotted toad \\
\hline Bufo woodhousei & Woodhouse's toad \\
\hline Hyla arenicolor & common treefrog \\
\hline Rana pipiens & leopard frog \\
\hline Crotaphytus collaris & collared lizard \\
\hline Gambelia wislizenii & leopard lizard \\
\hline Phrynosoma douglassii & short-horned lizard \\
\hline Sceloporus undulatus & western fence lizard \\
\hline Seloporus graciosus & sagebrush lizard \\
\hline Uta stansburiana & side-blotched lizard \\
\hline Urosaurus ornatus & tree lizard \\
\hline Eumeces multivirgatus & many-lined skink \\
\hline Cnemidophorus tigris & northern whiptail \\
\hline Cnemidophorus velox & plateau whiptail \\
\hline Coluber constrictor & racer \\
\hline Pituophis melanoleucus & gopher snake \\
\hline Thamnophis elegans & western terrestrial garter snake \\
\hline Crotalus viridis & western rattlesnake \\
\hline \multicolumn{2}{|l|}{ Birds } \\
\hline Ardea herodias & great blue heron \\
\hline Anas platyrhynchos & mallard \\
\hline Charadrius vociferus & killdeer \\
\hline Actitis macularia & spotted sandpiper \\
\hline Cathartes aura & turkey vulture \\
\hline Circus cyaneus & northern harrier \\
\hline Buteo jamaicensis & red-tailed hawk \\
\hline Haliaeetus leucocephalus & bald eagle \\
\hline Aquila chrysaetós & golden eagle \\
\hline Falco peregrinus & peregrine falcon \\
\hline Falco sparverius & American kestrel \\
\hline Phasianus colchicus & ringnecked pheasant \\
\hline Meleagris gallopavo & wild turkey \\
\hline Columbaa fasciata & band-tailed pigeon \\
\hline
\end{tabular}


Table A-2 (continued). Wildlife Species Expected to Occur On or Near the DOE Lease Tracts

\begin{tabular}{|c|c|}
\hline Scientific Name & Common Name \\
\hline \multicolumn{2}{|l|}{ Birds (continued) } \\
\hline Columbao livea & rock dove \\
\hline Zenaida macroura & mourning dove \\
\hline Chordeiles minor & common nighthawk \\
\hline Bubo virginianus & great horned owl \\
\hline Glaucidium gnoma & northern pigmy owl \\
\hline Otus trichopsis & western screech-owl \\
\hline Aeronautes saxatalis & white-throated swift \\
\hline Archilochus alexandri & black-chinned hummingbird \\
\hline Selasphorus playtcercus & broad-tailed hummingbird \\
\hline Ceryle alcyon & belted kingfisher \\
\hline Colaptes auratus & northern flicker \\
\hline Picoides villosus & hairy woodpecker \\
\hline Melanerpes lewis & Lewis's woodpecker \\
\hline Tyrannus verticalis & western kingbird \\
\hline Myiarchus cinerascens & ash-throated flycatcher \\
\hline Contopus sordidulus & western wood pewee \\
\hline Sayornis saya & Say's phoebe \\
\hline Empidonax wrightii & gray flycatcher \\
\hline Empidonax traillii extimus & southwestern willow flycatcher \\
\hline Eremophila alpestris & horned lark \\
\hline Tachycineta thalassina & violet-green swallow \\
\hline Stelgidopteryx serripennis & northern rough-winged swallow \\
\hline Hirundo pyrrhonota & cliff swallow \\
\hline Hirundo rustica & barn swallow \\
\hline Aphelocoma coerulescens & scrub jay \\
\hline Gymnorhinus cyanocephalus & piñon jay \\
\hline Pica pica & black-billed magpie \\
\hline Corvus brachyrhynchos & American crow \\
\hline Corvus corax & raven \\
\hline Sitta pygmaea & pygmy nuthatch \\
\hline Troglodytes aedon & house wren \\
\hline Catherpes mexicanus & canyon wren \\
\hline Salpinctes obsoletus & rock wren \\
\hline Polioptila caerulea & blue-gray gnatcatcher \\
\hline Sialia currucoides & mountain bluebird \\
\hline Turdus migratorius & American robin \\
\hline Lanius ludoviceanus & loggerhead shrike \\
\hline Mimus polyglottos & northern mockingbird \\
\hline Toxostoma bendirei & Bendire's thrasher \\
\hline Bombycilla cedrorum & cedar waxwing \\
\hline Vireo gilvus & warbling vireo \\
\hline Vireo solitarius & solitary vireo \\
\hline Vireo vicinior & gray vireo \\
\hline Dendroica petechia & yellow warbler \\
\hline Ictaria virens & yellow-breasted chat \\
\hline Pheucticus melanocephalus & black-headed grosbeak \\
\hline Guiraca caerulea & blue grosbeak \\
\hline Passerina amoena & lazuli bunting \\
\hline Pipilo erythrophthalmus & rufous-sided towhee \\
\hline Pooecetes gramineus & vesper sparrow \\
\hline Passerculus sandwichensis & savannah sparrow \\
\hline Chondestes grammacus & lark sparrow \\
\hline Spizella passerina & chipping sparrow \\
\hline Amphispiza bilineata & black-throated sparrow \\
\hline Sturnella neglecta & western meadowlark \\
\hline Euphagus cyanocephalus & brewer's blackbird \\
\hline Molothrus ater & brown-headed cowbird \\
\hline
\end{tabular}




\begin{tabular}{|c|c|}
\hline Scientific Name & Common Name \\
\hline \multicolumn{2}{|l|}{ Birds (continued) } \\
\hline Carduelis psaltria & lesser goldfinch \\
\hline Carduelis tristis & American goldfinch \\
\hline Carpodacus mexicanus & house finch \\
\hline Mammals & . \\
\hline Myotis lucifugus & little brown myotis \\
\hline Myotis velifer & cave myotis \\
\hline Myotis thysanodes & fringed myotis \\
\hline Myotis evotis & long-eared myotis \\
\hline Myotis californicus & California myotis \\
\hline Myotis yumanensis & Yuma myotis \\
\hline Myotis volans & long-legged myotis \\
\hline Myotis ciliolabrum & small-footed myotis \\
\hline Lasionycteris noctivagans & silver-haired bat \\
\hline Pipistrellus hesperus & western pipistrel \\
\hline Eptesicus fuscus & big brown bat \\
\hline Lasiurus cinereus & hoary bat \\
\hline Euderma maculatum & spotted bat \\
\hline Plecotus townsendii & western big-eared bat \\
\hline Antrozous pallidus & pallid bat \\
\hline Idionycteris phyllotus & Allen's big-eared bat \\
\hline Tadarida molossa & big freetail bat \\
\hline Tadarida brasiliensis & Mexican freetail bat \\
\hline Sylvilagus nuttalli & mountain cottontail \\
\hline Sylvilagus auduboni & desert cottontail \\
\hline Lepus californicus & black-tailed cottontail \\
\hline Eutamias minimus & least chipmunk \\
\hline Ammospermophilus leucurus & white-tailed antelope ground squirrel \\
\hline Citellus richardsoni & Richardson's ground squirrel \\
\hline Citellus variegatus & rock squirrel \\
\hline Thomomys talpoides & northern pocket gopher \\
\hline Perognathus flavus & silky pocket mouse \\
\hline Dipodomys ordi & Ord's kangaroo rat \\
\hline Castor canadensis & beaver \\
\hline Peromyscus crinitus & canyon mouse \\
\hline Peromyscus maniculatus & deer mouse \\
\hline Peromyscus truei & piñon mouse \\
\hline Onychomys leucogaster & northern grasshopper mouse \\
\hline Neotoma lepida & desert woodrat \\
\hline Ondatra zibethica & muskrat \\
\hline Zapus princeps & western jumping mouse \\
\hline Erethizon dorsatum & porcupine \\
\hline Canis latrans & coyote \\
\hline Urocyon cinereoargenteus & gray fox \\
\hline Procyon lotor & raccoon \\
\hline Mustella nigripes & black-footed ferret \\
\hline Mustella frenata & long-tailed weasel \\
\hline Mustella vison & mink \\
\hline Taxidea taxus & badger \\
\hline Spilogale putorius & western spotted skunk \\
\hline Mephitis mephitis & striped skunk \\
\hline Lutra canadensis & river otter \\
\hline Felis rufus & bobcat \\
\hline Felis concolor & mountain lion \\
\hline Odocoileus hemionus & mule deer \\
\hline Antilocapra americanus & pronghorn antelope \\
\hline Ovis canadensis mexicana & desert bighorn sheep \\
\hline Cervus canadensis & elk \\
\hline Bassariscus astutus & ringtail \\
\hline
\end{tabular}


Intentionally Blank 


\section{Appendix B \\ Resolution of Public Comments Regarding Draft Environmental Assessment for the \\ Uranium Lease Management Program}


Intentionally Blank 


\title{
Resolution of Public Comments Regarding
}

\author{
Draft Environmental Assessment \\ for the \\ Uranium Lease Management Program
}

DOE received the following public comments regarding the Draft Environmental Assessment for the Uranium Lease Management Program (dated May 1995). All section, page, and line numbers refer to the Draft EA. Resolutions to these comments are provided below and have been incorporated into the Final EA as appropriate.

\section{SPECIFIC COMMENTS}

Cotter Corporation offered the following specific comments:

Comment: Page 6, line 8-Does the exclusion of 20 leases now prevent them from ever being included in the lease program? All tracts should be available for future leasing.

Resolution: DOE's intent is to reclaim the 20 relinquished tracts and restore them to the public domain. However, if significant interest should arise, this EA does not preclude DOE from offering these tracts for lease in the future, either individually or collectively. The language in the EA will not be changed.

Comment: Page 10, line 11 - The end of the 10-year period should prompt the reissuance of the lease, if desired by the lessee, rather than merely prompt a re-evaluation.

Resolution: DOE's intent is to negotiate new leases for one 10-year period. Near the end of that 10-year period, DOE will re-evaluate the leasing program to determine if the leases/leasing program should continue. The resulting decision will be made at DOE's discretion. The language in the EA will not be changed.

Comment: Page 10, line 30 - What does the "further environmental review" constitute?

Resolution: "Further environmental review" could include, but might not be limited to, a site-specific NEPA analysis of a proposed action, consultation with outside agencies, or approval of a proposed action by outside agencies. Some examples of situations that would require outside-agency consultation or approval are listed on pages 10 and 13 in the EA. The language in the EA will not be changed. 
Comment: Page 13, line 1 - Contact with multiple agencies regarding threatened or endangered species and sensitive plant and wildlife is excessive. The current program requires a letter from the Colorado Division of Wildlife certifying the existence or nonexistence of such species. This program, coupled with the current site inspection program is sufficient to address this issue.

Resolution: Proposed actions on the lease tracts would require consultation with the Colorado Division of Wildlife or the U.S. Fish and Wildlife Service. Proposed actions off the lease tracts would require consultation with BLM. The language in the EA will be changed to read: "For all proposed surface disturbances, the leaseholder would be required to consult with the Colorado Division of Wildlife, U.S. Fish and Wildlife Service, and/or BLM, as appropriate, to determine whether threatened or endangered ..."

Comment: Page 13, line 9 - Current practice includes such a survey by BLM. A survey of this type is not warranted for each disturbance. Only an initial survey relative to the general area would seem appropriate.

Resolution: Completion of a cultural and historical survey would be required for all proposed surface disturbances before the disturbance occurs. If the "initial survey" included the proposed area of disturbance, then that survey could be used to meet the requirement. The language in the EA will not be changed.

Comment: Page 13, line 23 - The requirements stated in this paragraph should be the responsibility of the Lessor (DOE).

Resolution: The language in the EA will be changed to read: "For disturbances proposed in potential floodplain or wetland areas, the leaseholder would be required to determine, through consultation with the U.S. Army Corps of Engineers (COE), EPA, and the appropriate State agency, whether a jurisdictional floodplain or wetland was present. The leaseholder might need to propose mitigation measures in a Floodplain/Wetlands Assessment. DOE would review the proposed activity in accordance with 10 CFR 1022 and would approve or disapprove surface disturbance in conjunction with COE, EPA, and the appropriate State agency."

Comment: Page 13, line 39 - MSHA is the safety agency which regulates these sites. The leaseholder will continue to abide by applicable local, state and federal regulations, therefore, specific reference to regulatory agencies is not appropriate.

Resolution: DOE agrees that MSHA is the safety agency that regulates these sites; therefore, references to OSHA will be eliminated from this paragraph. 
Comment: Page 14, line 5 - NRC does not regulate mining operations. Accordingly, reference to NRC standards is not applicable.

Resolution: DOE recognizes that NRC does not have jurisdiction over mining operations; however, the referenced standard is applicable to lease operations to ensure public protection from radiation exposure. This standard has been accepted by DOE (DOE Proposed Rule, 10 CFR Part 834, Radiation Protection of the Public and the Environment) and EPA (EPA Notice, Federal Radiation Protection Guidance for Exposure of the General Public). For DOE-administered programs/actions that would involve sources of ionizing radiation created or influenced by human activities, DOE would require that the radiation exposure to the public be kept under the NRC standard. The language in the EA will not be changed.

Comment: Page 14, line 40 - NEPA assessments relate to major federal decisions. A NEPA assessment would not be necessary for each exploration plan.

Resolution: DOE actions require NEPA review (in accordance with 10 CFR 1021) and, in this circumstance, approval of the subject plan is the DOE action. The language in the EA will not be changed.

Comment: Page 15, line 6 - County road entry is already available for the leased tracts. Other right-of-way will be obtained as needed.

Resolution: The language in the EA is consistent with this comment and will not be changed.

Comment: Page 15, line 30 - The specific description of the drill site (i.e., dimensions) should not be included here.

Resolution: The dimensions stated in the EA are "approximate" to give readers an idea of the size of disturbance at a typical drill site. The language in the EA will not be changed.

Comment: Page 16, line 17 - See comment regarding OSHA relative to page 13, line 39.

Resolution: References to OSHA will be eliminated from the paragraph.

Comment: Page 16, line 31 - See comment regarding NEPA relative to page 14, line 40 .

Resolution: DOE actions require NEPA review (in accordance with 10 CFR 1021) and, in this circumstance, approval of the subject plan is the DOE action. The language in the EA will not be changed. 
Comment: Page 16, line 40 - See comment regarding NEPA relative to page 14 , line 40 .

Resolution: DOE actions require NEPA review (in accordance with 10 CFR 1021) and, in this circumstance, approval of the subject plan is the DOE action. The language in the EA will not be changed.

Comment: Page 17, line 9 - Off-lease activities are not under the purview of the DOE.

Resolution: The EA simply reiterates that the leaseholder would be required to comply with all State and Federal regulations. The language in the EA will not be changed.

Comment: Page 19, line 29 - Dedicated emergency equipment is not needed at each site if it is available via mobile deployment from another location.

Resolution: The language in the EA will be changed to read: "Some emergency equipment (e.g., first aid supplies, liquid spill-response supplies, fire extinguishers, etc.) would be maintained on site for accidents involving injuries to employees and/or minimal environmental damages. Additional emergency equipment (e.g., mine rescue equipment) would be maintained on site or at centralized locations that would allow for reasonable response times in accordance with MSHA requirements."

Comment: Page 19, line 44 - As Low As Reasonably Achievable (ALARA) concepts are not defined by DOE.

Resolution: The language in the EA will be changed to read: "If necessary, ... to minimize the potential for intrusion by humans and wildlife species and to reduce exposure to radioactive materials."

Comment: Page 27, line 9 - Reclamation should not follow temporary closure.

Resolution: The language in the EA will be changed to read: "Immediately following temporary closure, those disturbed areas identified by the leaseholder as not being needed for future operational activities would be promptly reclaimed. In addition, inventory items ..."

Comment: Page 27, line 22 - Waste (as referred to here) should explicitly exclude waste rock.

Resolution: The language in the EA will be changed to read: "Debris and waste (hazardous and nonhazardous) (excluding mine-rock waste) would be managed and, ..." 
Comment: Page 27, line 45 - Surface disturbances in unaffected areas are not justified in order to obtain topsoil for these locations.

Resolution: The EA text states that "topsoil might be borrowed from other areas of the lease tract;" these areas wouldn't necessarily be undisturbed or "unaffected." The language in the EA will not be changed.

Comment: Page 28, line 5-See comments relative to page 13 , line 1 .

Resolution: The language in the EA will be changed to read: "The Colorado Division of Wildlife and/or the U.S. Fish and Wildlife Service, as appropriate, would be contacted ..."

Comment: Page 28, line 8 - Wetland drainage and consequent elimination is allowed providing that discharge quality is not adversely affected.

Resolution: The leaseholder would be required to follow all regulations pertaining to wetland areas if it were determined that a wetland existed on the lease tract. The language in the EA will not be changed.

Comment: Page 49, line 43 - See comments relative to page 14, line 5 .

Resolution: DOE recognizes that NRC does not have jurisdiction over mining operations; however, the referenced standard is applicable to lease operations to ensure public protection from radiation exposure. This standard has been accepted by DOE (DOE Proposed Rule, 10 CFR Part 834, Radiation Protection of the Public and the Environment) and EPA (EPA Notice, Federal Radiation Protection Guidance for Exposure of the General Public). For DOE-administered programs/actions that would involve sources of ionizing radiation created or influenced by human activities, DOE would require that the radiation exposure to the public be kept under the NRC standard. The language in the EA will not be changed.

Comment: Page 58, line 24 - Stormwater management controls do not preclude water from reaching perennial waters. Alternately, these controls are constructed in order to control sediment transport.

Resolution: The language in the EA will be changed to read: "These storm-water management controls would be designed to reduce runoff from lease tract operational features, thus minimizing the amount of runoff reaching a perennial stream or river." 
Comment: Page 64, line 3 - The term "more effectively" relative to access restrictions should be more clearly defined.

Resolution: The language in the EA will be changed to read: "During mine operations, leaseholders would be required to restrict access to mine sites to adequately ensure public safety."

\section{U.S. Fish \& Wildlife Service offered the following specific comment:}

Comment: Section 4.10 - The southwestern willow flycatcher is now listed as "endangered;" you have "proposed" in the EA, and also some have been found on the San Miguel River near Uravan.

Resolution: The status of the southwestern willow flycatcher will be changed from "proposed" to "endangered" in Table 3 of the EA.

Colorado Division of Wildlife offered the following specific comments:

Comment: Section 4.10 - The CDOW has conducted bat survey work at numerous uranium mines in and around the project area over the past 2-3 years. The CDOW has conducted work on BLM administered lands to evaluate mines as bat roosts. The work suggests that many bat species, including all proposed candidate species, have been documented using old uranium mines in Colorado. These species include all of the following, which are also all recent additions to the candidate species lists by the USFWS: Plecotus townsendii, Myotis thysanodes, Myotis evotis, Myotis volans, Myotis ciliolabrum (subulantus in EA), and Myotis californicus. In addition, the following species have been documented: Myotis lucifugus and Eptesicus fuscus.

In addition, Euderma maculatum may occur in mines; the CDOW has recently heard of several documentations of spotted bats in abandoned mines. Also, Allen's big-eared bat, Idionycteris phyllotus, is likely to occur in Colorado near the Utah border and may utilize mines. This species is also a recent recommendation to the candidate list.

The CDOW recommends that prior to any reclamation work of mines, that an evaluation of said mines for use by bats be conducted. Important roosts should be protected for bats. The question of impacts to bat populations as a result of roosting in old uranium mines is still pending. But at this point, bat roosts should be evaluated and protected until such time that data indicates the best approach to the bats/uranium mine issue.

Any re-working of currently inactive mine sites should also be evaluated for bat use prior to mining activity. Consideration of evicting the bats, if found, or constructing alternative roosting habitat, should be conducted. 
Plecotus townsendii should be added to Table 3. Abandoned buildings should also be considered as potential bat roosts, and be evaluated and, if needed, protected for bats.

All ponds and open water sources are potential drinking spots for bats. Any sources that would have water quality problems should be mitigated so that bats, and other wildlife, cannot drink from them. Good sources of water should be left open for access by bats and wildlife.

The CDOW is interested in protecting bats and their habitat, and is willing to work with the involved parties as needed on this issue. Thank you for your consideration of these comments.

Resolution: The following species and associated information will be added to Table 3 of the EA:

\begin{tabular}{||l|l|l|l||}
\hline \multicolumn{1}{|c|}{$\begin{array}{c}\text { Common } \\
\text { Name }\end{array}$} & \multicolumn{1}{|c|}{$\begin{array}{c}\text { Scientific } \\
\text { Name }\end{array}$} & \multicolumn{1}{|c|}{ Status } & \multicolumn{1}{|c|}{ Occurrence on Lease Tracts } \\
\hline $\begin{array}{l}\text { Western big- } \\
\text { eared bat }\end{array}$ & $\begin{array}{l}\text { Plecotus } \\
\text { townsendii }\end{array}$ & Candidate & $\begin{array}{l}\text { The western big-eared bat, although not specifically } \\
\text { documented on the lease tracts, is known to use } \\
\text { uranium mines in Colorado. }\end{array}$ \\
\hline $\begin{array}{l}\text { California } \\
\text { myotis }\end{array}$ & $\begin{array}{l}\text { Myotis } \\
\text { californicus }\end{array}$ & Candidate & $\begin{array}{l}\text { The California myotis, although not specifically } \\
\text { documented on the lease tracts, is known to use } \\
\text { uranium mines in Colorado. }\end{array}$ \\
\hline $\begin{array}{l}\text { Allen's big- } \\
\text { eared bat }\end{array}$ & $\begin{array}{l}\text { Idionycteris } \\
\text { phyllotus }\end{array}$ & Candidate & $\begin{array}{l}\text { Allen's big-eared bat, although not specifically } \\
\text { documented on the lease tracts, is known to use } \\
\text { uranium mines in Colorado. }\end{array}$ \\
\hline
\end{tabular}

In Table 3, the following notation will replace the existing notation under "Occurrence on Lease Tracts" for the fringed myotis, long-eared myotis, long-legged myotis, small-footed myotis, and Yuma myotis: "The myotis, although not specifically documented on the lease tracts, is known to use uranium mines in Colorado."

In Table 3, Myotis volvans will be changed to Myotis volans. Myotis subulatum will be changed to Myotis ciliolabrum.

In Table A-2, Myotis subulantus will be changed to Myotis ciliolabrum. Plecotis townsendi will be changed to Plecotus townsendii. Idionycteris phyllotus (Allen's big-eared bat) will be added.

The sentence, "With the exception of the southwest willow flycatcher (a neotropical migrant) and the spotted bat, none of these species is protected under the Endangered Species Act," on page 42 , lines 34,35 , and 36 , will be deleted from the text. 
The EA text on page 43 , line 8 , will be changed to read:

Bats-Lease tracts 5, 6, 7, 9, 11, 13, 13A, 15, 18, 19, 21, 22A, and 25 have mine shafts, adits, and inclines/declines that could provide roosting habitat for bats. No evidence of bat habitation has been found at these lease tracts. However, the Colorado Division of Wildlife and BLM (Navo 1995, Ingersol 1994) have observed the spotted bat, western big-eared bat, fringed myotis, long-eared myotis, long-legged myotis, small-footed myotis, California myotis, and Yuma myotis, all of which are candidates for protection under the Endangered Species Act, in abandoned uranium mines in Colorado.

The following sentence will be added to the end of the paragraph on Neotropical Migratory Birds on page 43, line 20: "The southwest willow flycatcher is Federally listed as an endangered species."

CDOW's other recommendations and concerns are addressed generally in the EA text on page 28 , line 5 , and on page 13 , line 1 .

\section{GENERAL COMMENTS}

\section{L. \& J. Hubbard offered the following general comment:}

Comment: We feel that the DOE should continue the Uranium Management Program by retaining the lands in the withdrawn status and lease the lands through noncompetitive negotiations with former lease holders and other prospective qualified leasers who are interested in the program. We would like to see access roads left intact and the land available for multiple use.

Resolution: No response needed.

Blake Mining Company offered the following general comment:

Comment: This is in response to the meeting on the Uranium Leasing Program which was held in Naturita, Colorado, on Monday, June 12, 1995, at the Naturita Community Hall. We would like to take this time to thank you and the Department for arranging this meeting to inform us and the community of the DOE's proposed plans regarding the leasing program.

Resolution: No response needed. 
State of Utah, Department of Community \& Economical Development, Division of State History, Utah State Historical Society, offered the following general comment:

Comment: The Utah State Historical Preservation Office received the Draft Environmental Assessment for the Uranium Lease Management Program on June 5, 1995. After consideration of the two alternatives outlined, the Utah Preservation Office concurs with the culture history outline and the conclusions of the two recommendations. This information is provided on request to assist the Department of Energy with its Section 106 responsibilities as specified in 36CFR800.

Resolution: No response needed.

State of Utah, Governor's Office of Planning and Budget, Resource Development Coordinating Committee offered the following general comment:

Comment: The Resource Development Coordinating Committee (RDCC), representing the State of Utah, has reviewed this proposal and has no comments at this time. The Committee appreciated the opportunity to review this proposal.

Resolution: No response needed.

Environmental Protection Agency, Region 8, Denver, Colorado, offered the following general comment:

Comment: EPA, Region 8, has reviewed a copy of the Draft Environmental Assessment for the Uranium Lease Management Program and we really don't have anything to comment on. It looks like you have touched all the bases; it looks like a pretty good programmatic effort to look at the impacts and alternatives. You used EPA's idea to do a risk assessment looking at a camper camping on the tailings for 14 days and registering the impacts, and it comes in less than the NRC Standards. That would seem to be a worst case, if somebody would be interested enough to camp on tailings for 14 days. So unless you hear [further], just figure that the draft looks okay to [EPA] and [EPA doesn't] have anything further to add.

Resolution: No response needed. 


\section{U.S. DEPARTMENT OF ENERGY}

Finding of No Significant Impact, Uranium Lease Management Program

AGENCY: U.S. Department of Energy

ACTION: Finding of No Significant Impact

SUMMARY: The U.S. Department of Energy (DOE) has prepared a programmatic environmental assessment (EA) of the proposed action to continue leasing withdrawn lands and DOE-owned patented claims for the exploration and production of uranium and vanadium ores. The Domestic Uranium Program regulation, codified at Title 10, Part 760.1, of the U.S. Code of Federal Regulations (CFR), gives DOE the flexibility to continue leasing these lands under the. Uranium Lease Management Program (ULMP) if

- the agency determines that it is in its best interest to do so. A key element in determining what is in DOE's "best interest" is the assessment of the environmental impacts that may be attributable to lease tract operations and associated activities. On the basis of the information and analyses presented in the EA for the ULMP, DOE has determined that the proposed action does not constitute a major Federal action significantly affecting the quality of the human environment, as defined in the National Environmental Policy Act (NEPA) of 1969 (42 United States Code 4321 et seq.), as amended. Therefore, preparation of an environmental impact statement is not required for the ULMP, and DOE is issuing this Finding of No Significant Impact (FONSI).

\section{SUPPLEMENTARY INFORMATION:}

\section{Background}

In the post-World War II era, the U.S. Atomic Energy Commission (AEC) was charged with the responsibility of developing a supply of domestic uranium adequate to meet the nation's defense needs. That responsibility was met through the Ore Purchase Program, the Exploration Program, and the initial Uranium Leasing Program (1949-1962). These programs gave AEC the authority to withdraw Federal lands for the exploration and development of a viable domestic uranium source.

In 1974, the ULMP was initiated under the Domestic Uranium Program (10 CFR 760.1). The program's purpose was to maintain and preserve the nation's immediately accessible supply of domestic uranium and vanadium ores, to maintain a viable domestic mining and milling infrastructure required to produce and mill these ores, and to provide assurance of a fair monetary return to the U.S. Government. AEC (and its successor agencies, the U.S. Energy Research and Development Administration [ERDA] and DOE) was tasked with administering the program. Forty-three lease tracts located in Colorado (38 lease tracts), Utah (4 lease :tracts), and New Mexico (1 lease tract) that comprise approximately 25,000 acres were included in the ULMP. Most of these lease tracts lie in a mineralized area known as the Uravan Mineral Belt, which includes a significant, if not dominant, portion of the known domestic uranium ore reserves. 
Since 1974, AEC, ERDA, and DOE (in succession) have controlled and administered these 43 lease tracts for the exploration and development of viable uranium and vanadium resources. In 1984, only 33 of the original 43 lease agreements were renewed for a second 10-year period under the leases' renewal option. During the ensuing n10 years, three additional lease agreements were either relinquished to DOE or terminated by DOE. In 1994, the remaining 30 lease agreements were allowed to expire. Former leaseholders for 22 of the 30 lease tracts indicated to DOE a desire to participate in a future leasing program. The 22 tracts leased by these former leaseholders are addressed in the EA. The former leaseholders for the remaining 8 lease tracts requested relinquishment of their respective leases. While the NEPA process is being completed, the former leaseholders are being allowed to continue maintenance, security, and reclamation activities at the lease tracts to ensure that the mines and associated facilities do not deteriorate.

\section{Proposed Action}

DOE proposes to continue the ULMP by retaining the lands in withdrawn status and leasing the lands to former leaseholders interested in continuing their participation in the program. Continuation of the ULMP would allow 10 years of exploration, development, and mining on the 22 leàse tracts. At the end of 10 years, DOE would evaluate the ULMP to determine if leasing activities should continue.

On the basis of current demand for uranium and vanadium, the level and types of mining activity expected under the proposed action could be similar to historical activities that occurred during the 1974-1994 lease period. Historically, activities conducted on the lease tracts occurred in three phases: preoperational (exploration), operational (mining), and postoperational (reclamation). On 7 of the lease tracts, only preoperational activities occurred; on the remaining 15 lease tracts, two or more phases occurred. Of the 11,536 acres encompassed by the 22 lease tracts, approximately 258 acres were actually disturbed or environmentally affected by past lease tract operations. About 75 percent of this disturbance (approximately 190 acres) was associated with operations on one lease tract.

Under the proposed action, new lease agreements, including applicable stipulations, would be issued to leaseholders before operations were resumed. DOE approval would be required for all lease activities.

Some new surface disturbances would require review or approval by agencies outside DOE, such as the Colorado Mined Land Reclamation Board, Colorado Division of Wildlife, Colorado Historical Society, U.S. Fish and Wildlife Service, U.S. Bureau of Land Management, U.S. Army Corps of Engineers, and U.S. Environmental Protection Agency (EPA). Prior to starting many activities, leaseholders would be required to obtain permits from, or comply with regulations specific to, these agencies. Consultation with the appropriate agencies would be required to ensure mitigation of impacts to natural and cultural resources. 
Leaseholders also would be required to protect the health and safety of mine workers and the public by complying with Mine Safety and Health Administration (MSHA), U.S. Nuclear Regulatory Commission (NRC), and EPA regulations.

New surface disturbances associated with the three phases of mining are expected to affect an estimated 250 acres (about 2 percent of the 11,536 acres within the lease tracts) of previously undisturbed land. Approximately 50 percent of this new disturbance would be associated with the placement of mine-rock waste piles. Other new disturbances would be associated with roads, drill pads, small (encompassing less than 5 acres) surface mines, mine portals, or other surface-plant support facilities.

\section{Environmental Impacts}

The EA indicates that the environmental impacts from the proposed action would be minimal and are summarized in this FONSI. Impact descriptions have been made on the assumption that mining activities would continue at a level similar to that of historical activities and that an estimated 250 acres of previously undisturbed land would be affected during the. next 10 years.

\section{Socioeconomics}

If the market were to allow a resumption of uranium and vanadium production, the local economies of communities in Montrose, San Miguel, and Fremont Counties, Colorado, and San Juan County, Utah, would benefit by increases in the number of jobs (up to an additional 250 jobs) and local and secondary wages. The increase in jobs could increase housing construction in the smaller communities near the lease tracts (located in Montrose and San Miguel Counties) and near the processing mills (located near Canon City, Colorado [Fremont County], and Blanding, Utah [San Juan County]).

\section{Transportation}

Under the proposed action, an average of 30 trucks (or truck-and-pup combinations) per day would transport uranium and vanadium ores to the processing mills near Canon City, Colorado, and/or Blanding, Utah. This increase in truck traffic along the transportation routes is not expected to (1) noticeably increase the number of accidents that occur along the routes, (2) affect the environment, or (3) increase radiation exposure to humans. Assuming a transportation rate of 30 trucks per day, a maximum of 0.12 deaths and 7.4 injuries per year could be expected to occur from ore-truck accidents. If an accident involving a spill were to occur, impacts to natural resources could include soil and vegetation disturbance (from cleanup activities) or, if the spill were to occur in a water source, a temporary increase in turbidity and total suspended solids. Wildife could be injured or killed along the haul routes through collisions with haul trucks. Species most likely to be affected would include mule deer, elk, porcupines, rabbits, prairie dogs, ground squirrels, golden eagles, and turkey vultures. Radiation exposures to the truck driver and public during ore transport would be negligible and well below applicable standards. 


\section{Land Uses}

Land uses on and adjacent to the lease tracts would continue to include mining (considerable mineral exploration and development has occurred historically in the vicinity of the lease tracts), recreation, piñon-juniper harvesting, and grazing. Activities occurring on the lease tracts under the proposed action would constitute a small portion of the activities occurring on lands adjacent to the lease tracts.

Mining: Mining of uranium and vanadium resources under the proposed action would deplete domestic reserves; however, the continuation of associated exploration activities could result in the discovery of previously unidentified ore reserves.

Recreation: Resuming preoperational, operational, and postoperational activities under the proposed action would have minimal effects on recreation in the lease tract areas. Potential increases in noise, dust, and human activity might deter recreationists from using public lands adjacent to the lease tracts; however, the numerous unimproved roads in the vicinity of the lease tracts would allow easy access to other areas.

Timber Harvesting: A small number of piñon pine and juniper trees could be removed as a result of access road and drill pad construction or mine site expansion. Because of the abundance of piñon pine and juniper on and adjacent to the lease tracts, however, impacts to these species would be negligible.

Agriculture and Grazing: Under the proposed action, a maximum of 5 to 8 animal unit months of forage (the amount of forage required to feed one cow and one calf for 5 to 8 months) could be lost over a period of 10 years as a result of surface-disturbing . activities associated with preoperational and operational activities. This small loss in forage would have a negligible effect on the overall volume of forage in local grazing allotments.

\section{Air Quality}

Resumption of lease activities under the proposed action would result in local increases in fugitive dust. Regional air quality is not expected to be affected by these local increases. The leaseholder would be responsible for obtaining an air emissions permit from the State of Colorado if lease operations could result in the exceedance of the State opacity limit. However, lease tract operations would not likely require an air emissions permit.

\section{Groundwater}

Preoperational, operational, and postoperational activities under the proposed action are not expected to adversely affect groundwater resources on any of the lease tracts. The shallowest significant groundwater is in the Entrada Sandstone. Because this aquifer is generally several hundred feet below the surface of the lease tracts, surface-disturbing activities would have no effect on the aquifer. Downward percolation of recharge water, which could infiltrate at the surface, would be slowed considerably by the presence of the thick (several hundred feet), relatively impermeable Brishy Basin Member of the 
Morrison Formation. The Entrada aquifer is hydrologically separated from the surface by the Brushy Basin and Salt Wash Members of the Morrison Formation and by the Summerville Formation.

Subsurface activities would have negligible effects on groundwater. With the exception of mines on three lease tracts, groundwater would not be present in notable amounts within the subsurface areas encountered during mining. Water might be brought into underground mines during drilling to prevent dust from becoming airborne and to remove cuttings from drill bits. This water would not be present in large enough quantities to transport mineral contaminants from the ore-bearing layer to underlying layers. Even if contaminants were to percolate downward, the Entrada aquifer would not be affected because it is hydrologically separated from the ore-bearing layer by the low-permeability Summerville Formation. In the three mines where water is present within the ore-bearing layer, groundwater would be pumped into surface treatment ponds and would not be available for seepage into underlying layers.

\section{Surface Water}

Potential impacts to surface water would be negligible under the proposed action. On disturbed areas of the lease tracts, the potential for erosion and transport of contaminant-laden sediments would be minimized by the implementation of storm-water management controls that would be required by the lease agreements and the Colorado Mined Land Reclamation Board. The storm-water management controls would ensure that runoff from lease tract features would not reach a perennial stream or river. Additionally, water released from treatment facilities to the environment would be required to meet all applicable National Pollutant Discharge Elimination System requirements.

\section{Soils}

Under the proposed action, an estimated 250 acres of soil could be expected to be disturbed by preoperational and operational activities. Disturbance of the soil surface and removal of vegetation would increase the soil erosion potential. Adverse impacts would be minimized by incorporating erosion-control techniques (e.g., use of water bars, vegetation, erosion-control fabric, and land contours) in the construction design and by reclaiming disturbed areas that are no longer needed for routine, operations.

\section{Vegetation}

Preoperational and operational activities under the proposed action could be expected to disturb or destroy native plant communities and cryptobiotic soil crusts on an estimated 250 acres of presently undisturbed land.

\section{Wildlife}

Under the proposed action, wildlife habitat would likely be lost as a result of vegetation removal, surface disturbance, and rock blasting during preoperational and operational activities. For animals that have large home ranges (e.g., deer, birds of prey, coyotes); 
mine-related habitat loss would have only minimal impacts. For animals that have small home ranges or that have specific habitat requirements (e.g., rodents, rabbits, and bats), displacement and some localized loss of population would be expected.

Wildlife displacement from increased noise, light, traffic, and other human activities probably would occur to some extent on all of the lease tracts. Large mobile animals would be affected less than small animals that depend exclusively on local habitat. A negligible number of small animals also would be lost as a result of accidental roadkill.

\section{Cultural/Historical Resources}

The leaseholder would be required to inventory areas targeted for disturbance and, if cultural/historical sites were present, to develop a mitigation plan to protect the sites. The State Historic Preservation Officer would approve the mitigation plan before surface disturbance was approved by DOE. With implementation of mitigation measures, adverse impacts to existing cultural/historical resources are expected to be negligible.

\section{Visual Resources}

Under the proposed action, the primary visual impacts would be barren areas and dust associated with preoperational and operational activities. The severity of the visual impacts would be dependent on the location of the disturbance and its visibility from access roads or corridors. Overall, proposed activities are not expected to adversely affect natural contrasts, colors, or skylines that occur throughout the lease tract areas.

\section{Wilderness Areas}

Under the proposed action, the only activities that would be visible from or within hearing distance of the Dolores River Canyon Wilderness Study Area (WSA) would be those that occurred on the uppermost elevations of two of the lease tracts. The two lease tracts are approximately 1 mile south of the WSA and are geographically separated from the WSA by deep canyons. Exploratory drilling, which has occurred historically, would be the most likely activity to occur on the upper elevations of the two lease tracts. Depending upon the wind direction and velocity, a WSA visitor could potentially see dust or hear noise emanating from the lease tracts. Because drilling is typically short term, the impacts, if any, are not anticipated to be long term. If mining were to occur on the lease tracts, operational activities would most likely occur at lower elevations that would not be visible from the WSA.

\section{Noise}

Minor to moderate increases in local noise levels would occur on lease tracts during preoperational and operational activities. Noise associated with preoperational activities such as drilling and access-road construction generally would be short term; noise associated with operational activities probably would be intermittent but long term. 
The sections of the Dolores River that are proposed for Wild and Scenic status would not be affected by the proposed action.

\section{Floodplains and Wetlands}

Three lease tracts contain wetland-type vegetation that is supported by mine dewatering activities and storm-water accumulation. If mining activities warranted the dredging or filling of areas containing wetland-type vegetation, compliance with the Clean Water Act could be required, depending on whether the areas were considered "waters of the U.S." under U.S. Army Corps of Engineers regulations. Floodplain and wetland areas are not expected to be adversely affected under the proposed action.

\section{Human Health}

Under the proposed action, humans could be exposed to radiological and nonradiological hazards on the lease tracts. The level of impact would depend upon the type and level of mine operation. During all phases of mine operation, the leaseholder would be required to ensure protection of workers by providing proper training and protective equipment, as specified by MSHA. The leaseholder also would be responsible for controlling public access to the mine sites during all phases of mine operation. The maximum total effective dose equivalent that would be received by workers or the public is expected to be 79 millirems per year, which is below the NRC standard of 100 millirems per year.

\section{Alternatives to the Proposed Action}

\section{No Action Alternative}

Under the No Action Alternative, DOE would not issue leases on the withdrawn lands, and all mining activities currently being performed on the lease tracts would cease. Reclamation activities would be initiated by former leaseholders immediately following DOE approval of individual reclamation plans. DOE would be responsible for monitoring and evaluating reclamation activities in accordance with the reclamation plans and with the binding environmental stipulations contained in the former lease agreements. Following completion of reclamation activities, DOE would retain the lands in withdrawn status. DOE's responsibilities would then be limited to periodic inspections of the reclaimed sites.

This alternative would not allow the U.S. Government immediate access to domestic uranium and vanadium ore reserves. In addition, socioeconomics of local communities would be adversely affected over the long term by the elimination of work opportunities associated with exploration and mining activities on the lease tracts. Most natural and cultural resources, however, would realize a net positive impact as a result of the reduction in access to remote areas of the lease tracts and reclamation of disturbed areas. 
The ULMP Termination Alternative would be the same as the No Action Alternative, with one exception: following completion of reclamation activities, DOE would relinquish the lease tracts to the U.S. Bureau of Land Management for return to the public domain. This alternative would not allow the U.S. Government immediate access to domestic uranium and vanadium ore reserves and would not ensure long-term access to the reserves. Impacts under this alternative would be the same as those under the No Action Alternative.

FINDING: On the basis of the preceding information and analyses presented in the EA, DOE has determined that the proposed action does not constitute a major Federal action significantly affecting the quality of the human environment, as defined by NEPA. Therefore, preparation of an environmental impact statement is not required for the ULMP, and DOE is issuing this FONSI.

PUBLIC AVAILABILITY: Copies of the EA (DOE/EA-1037) are available from

Ray Plieness, Project Manager, Uranium Lease Management Program

U.S. Department of Energy Grand Junction Projects Office

P.O. Box 2567

Grand Junction, Colorado 81502-2567

(970) 248-6091.

\section{FOR FURTHER INFORMATION ON THE NEPA PROCESS, CONTACT:}

Jeff Robbins, NEPA Compliance Officer, Environmental Protection Division U.S. Department of Energy Albuquerque Operations Office

P.O. Box 5400

Albuquerque, New Mexico 87115

(505) 845-4426.

Issued in Albuquerque, New Mexico, this 22 day of August_, 1995.

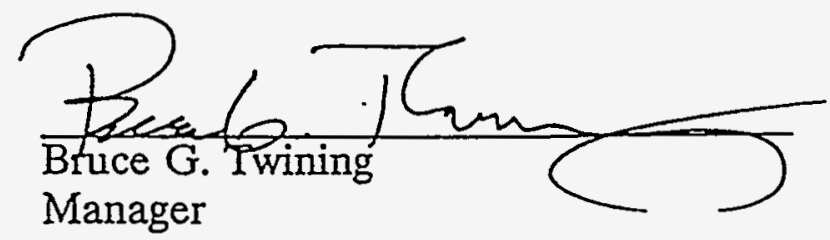

